THE USE OF

LAND CLASSIFICATION

IN

RESOURCE ASSESSMENT

AND

RURAL PLANNING

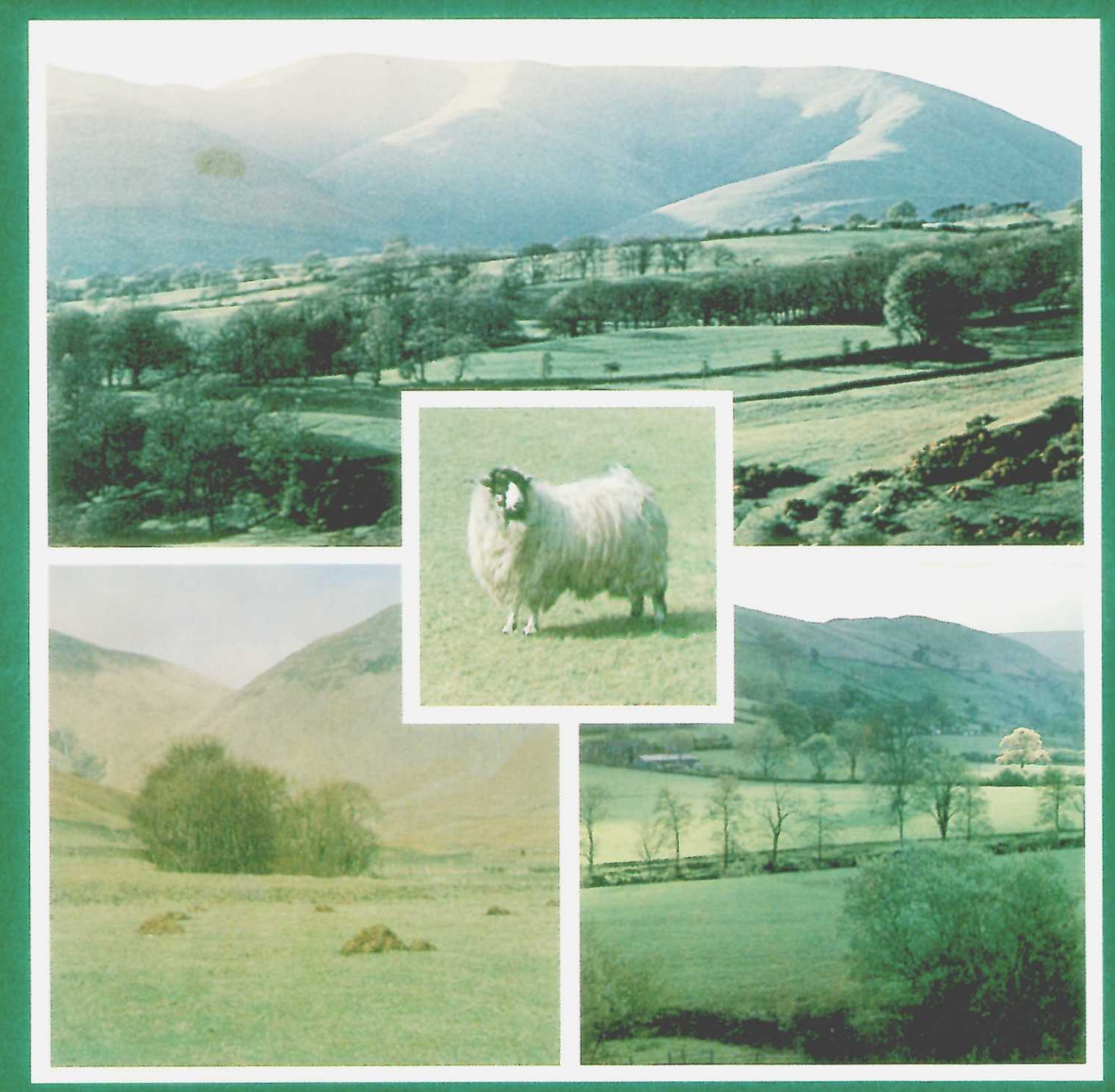

\title{
Institute of Terrestrial Ecology
}

Natural Environment Research Council 



\section{Natural Environment Research Council Institute of Terrestrial Ecology}

\section{THE USE OF LAND CLASSIFICATION IN RESOURCE ASSESSMENT AND RURAL PLANNING}

A report on methods developed at the

Institute of Terrestrial Ecology and Cumbria County Council

Roger S. Smith

Department of Soil Science

Faculty of Agriculture

University of Newcastle upon Tyne 
Printed in Great Britain by

The Burlington Press (Cambridge) Ltd

Cambridge

c) Copyright 1982

Published in 1982 by

Institute of Terrestrial Ecology

68 Hills Road, Cambridge, CB2 1LA.

ISBN 0904282627

\section{Cover}

Top: Howgill Fells from Danny Bridge, Garsdale. Background is Sedbergh land classes 7 and 8 ; foreground land class 14. Photograph Colin Armitstead. Centre: Kendal rough fell ewe at Cautley Thwaite, Sedbergh land class 16. Photograph Roger Smith. Bottom left: Yarlside and Cautley Spout, Rawthey Valley. Sedbergh land classes 2 and 8 in background and 16 in foreground. Photograph Roger Smith. Bottom right: Dentdale, a view across the valley bottom (Sedbergh land class 13) to the permanent pastures (Sedbergh land class 16) and rough grassland (Sedbergh land classes 9 and 10) of Helms Knott. Photograph Roger Smith.

The Institute of Terrestrial Ecology (ITE) was established in 1973 , from the former Nature Conservancy's research stations and staff, joined later by the Institute of Tree Biology and the Culture Centre of Algae and Protozoa. ITE contributes to and draws upon the collective knowledge of the fourteen sister institutes which make up the Natural Environment Research Council, spanning all the environmental sciences. The Institute studies the factors determining the structure, composition and processes of land and freshwater systems, and of individual plant and animal species. It is developing a sounder scientific basis for predicting and modelling environmental trends arising from natural or man-made change. The results of this research are available to those responsible for the protection, management and wise use of our natural resources.

About one quarter of ITE's work is research commissioned by customers, such as the Nature Conservancy Council who require information for wildlife conservation, the Department of Energy, the Department of the Environment, and the EEC. The remainder is fundamental research supported by NERC.

ITE's expertise is widely used by international organisations in overseas projects and programmes of research.

Dr. R. S. Smith

Department of Soil Science

Faculty of Agriculture

The University

Newcastle upon Tyne

NE1 7RU 


\section{CONTENTS}

$\begin{array}{ll}\text { Acknowledgements } & 4\end{array}$

$\begin{array}{ll}\text { Preface } & 5\end{array}$

$\begin{array}{lc}\text { Summary } & 6\end{array}$

$\begin{array}{lll}\text { Introduction } & 7\end{array}$

The planning background $\quad 9$

Stage 1: The grouping of grid squares into land classes 11

Grid size $\quad \ldots \quad 11$

The choice of map attributes $\quad 12$

The land classification and its interpretation $\quad 15$

Stage 2: The sample survey of grid squares from each land class $\quad 19$

$\begin{array}{ll}\text { Types of data and sample size } & 19\end{array}$

$\begin{array}{ll}\text { A tree cover survey of Cumbria } & 26\end{array}$

$\begin{array}{ll}\text { Vegetation differences between areas } & 28\end{array}$

Stage 3: The production of alternative rural land use strategies. 30

Development of a model for rural land use $\quad$ - 30

The collection of productivity data for the Sedbergh model 30

Other data required by the model $\quad .33$

One possible strategy 33

Stage 4: The evaluation of the alternative strategies against criteria not used initially to define them 35

Discussion 36

$\begin{array}{ll}\text { Bibliography } & 38\end{array}$

Annex: The agricultural and forestry productivity of the land classes in the Sedbergh area $\quad 40$ 


\section{Acknowledgements}

This report is the outcome of 5 years of close cooperation between the Institute of Terrestrial Ecology (Merlewood Research Station) and Cumbria County Council (County Planning Department). Many individuals in both these organisations and in other bodies have contributed to the development of the techniques discussed. As such, it is invidious to separate some people from the many contributors. However, I am particularly indebted to R. G. H. Bunce and O.W. Heal (ITE) for their support and encouragement throughout the work, and also to D. K. Lindley, C. J. Barr and I. Bishop. My ex-colleagues at Cumbria County Council similarly provided much support, even when the work appeared to be more esoteric than was necessary for the development of structure and local plans, and I am particularly grateful to R. D. Donnison and M. Lamb in this respect. Of those employed by the many organisations concerned with rural land use, I must thank the following for their interest and criticisms of the work: J. Wright and J. Cowie (Ministry of Agriculture); C. Bendelow (Soil Survey of England and Wales); S. Tomkins and J. Voysey (Forestry Commission); D. Wright (Nature Conservancy Council); R. V. Crawley and P. Brown (Yorkshire Dales National Park). However, I must emphasise that the views propounded here are mine and should not necessarily be construed as also being those of any of the individuals or organisations mentioned above.

Roger S. Smith University of Newcastle 


\section{Preface}

ITE's original research on land classification developed independently from research at the Merlewood Research Station on vegetation classification in British woodlands. At an early stage in this development, however, it became apparent that the methods then being developed were capable of being used for the solution of practical problems in county structure plans. Roger Smith, who at that time was on the staff of Cumbria County Council, worked closely with ITE staff in the application of land use classification to a wide- range of problems associated with resource assessment and rural planning. It is especially valuable, therefore, to have the evaluation of the application of the land classification methods developed by ITE to these problems contained in this publication.

J. N. R. Jeffers Director, ITE 


\section{Summary}

1. A method for surveying the ecological characteristics, forestry, farming and conservation resources of upland areas is described, and its use in generating alternative land use strategies is examined. The method is developed in 4 stages.

2. The first stage is the division of the survey area into grid squares. Sample squares are used for the measurement of attributes from Ordnance Survey and other maps. A land classification is developed from these data and all the grid squares in the area are allocated a land class. The map attributes characteristic of each land class are used to initially describe them.

3. In the second stage, each land class is characterised by field survey. The land classes are used as strata for sampling ecological, land use, and land capability characteristics. These sample data can be used to produce predictive maps and to assess the total resources in the survey area.

4. The mean values for the land class characteristics are used in the third stage to produce alternative resource strategies for rural land use. The agricultural capability is assessed in terms of the outputs of meat, milk and wool, and the forestry capability is assessed in terms of the yield of timber from each land class. Alternative strategies for agricultural and forestry development are formulated in terms of the acceptable minimum levels for milk, meat and timber, etc; the areas within which the present land use is preferred constraints on the use of certain types of land, eg the retention of agriculture on land of the highest capability; and the output which is most desired. The land use pattern which gives the maximum amount of the most desired output is calculated using a linear programming model. These patterns are the alternative strategies.

5. The final stage is the evaluation of each strategy against criteria not used initially to define them. The restriction of the third stage to the most easily quantified criteria excluded landscape and wildlife conservation from consideration. These are now brought into the analysis.

6. This technique of land classification and subsequent land use modelling is explained through the use of examples from Cumbria. It has developed through close co-operation between the Institute of Terrestrial Ecology and Cumbria County Council in pursuit of a better understanding of rural land use potential. 


\section{Introduction}

Most surveys of countryside characteristics such as land form, soils and ecosystems have a single purpose. They may be aimed firstly at assessing the agricultural or the forestry potential, or secondly they may be a simple categorisation and mapping of specific characteristics. The Ministry of Agriculture's Agricultural Land Classification is an example of the first type. The land is graded into 5 classes based on the physical limitations for farming. It aims to map the agricultural potential and is based upon an evaluation of soils, geological and topographical characteristics. It has been extended in their "Hills and Uplands Classification" whereby the agricultural potential of upland areas is mapped in detail. The Geological Survey and the Soil Survey of England and Wales map respectively the geological and soil characteristics of tracts of countryside. These are examples of the second type of survey where the variation of specific characteristics is mapped in considerable detail. The land use maps of the Second Land Utilization Survey are related to this second type, in that they are concerned with the details of present rather than potential use.

Surveys of both types often aim to produce a complete assessment for a given area. Given sufficient time, a field by field survey is quite feasible as long as an adequate classification is available for the resource that is being assessed. Complete surveys are usually done in bits and pieces, like a jigsaw puzzle. When completed, the characteristics of the surveyed area can be categorised from each piece of the jigsaw.

Complete survey methods have severe limitations if the time available is not sufficient to enable the whole area to be covered. If considerable resources in terms of money and manpower are not available, one way by which the area can be covered is by reducing the detailed information gathered: Vegetation surveys provide a good example of this problem. Vegetation is a mix of plants, the particular mix of species depending on the environmental conditions that are and have been acting in the area in question and on the interactions between the plants themselves. This mix is the best definition of the plant community and is assessed usually by some quantitative technique using sample quadrats. Shimwell (1971) gives a description of the many techniques available for the collection and analysis of such data. Such quantitative methods requiring the itemising of all plant species in quadrats are usually so time-consuming that surrogates are often used in complete surveys when time is limited. The main physical characteristics, the visually dominant species and the land use, are most often used as surrogates for 'plants in quadrats' data, thereby reducing the total work load involved in vegetation surveys to enable the whole of a survey area to be assessed.

Information on the ecological resources of Cumbria was sought by Cumbria County Council in 1975, as background data for the county structure plan, and this was required by 1977 if possible. With a land area approaching 7,000 square kilometres, even a simple classification of these resources would not have made possible a complete survey of the county in 2 years. Information on nature reserves and Sites of Special Scientific Interest was available from the Nature Conservancy Council, but there was very little information on the types and distribution of the commoner ecosystems. A search was, therefore, made for some form of sample survey in order to arrive at an estimate of the ecological resources. In the context of the County Planning Authority, a complete survey was not considered to be necessary. Site surveys for planning applications and local plans would have to be carried out regardless of any county-wide survey. Even if a site had been visited before, it would still need to be revisited to assess specific features applicable to a planning application. Therefore, the main requirement of a survey was that it should provide a framework to which such sites could be related.

At this time, the Institute of Terrestrial Ecology (ITE) was investigating a method of classifying land using Ordnance Survey maps, using this classification as strata for sampling ecological parameters (Bunce et al. 1975). The potential of the method had been explored in the Shetland Isles (Milner 1978) and was recognised by the County Council. It was used for an ecological survey of Cumbria and developed further for assessments of tree cover, hedgerows and landscape (Bunce \& Smith 1978). The rural planning aspects of the work received a considerable impetus through the development of a linear programming model based on the land classification (Bishop 1978). This showed that the land classification could not only be used to predict the quantity and distribution of the ecosystems in Cumbria, but could also be used to survey agricultural and forestry potential. More importantly, it showed that a framework had been developed that allowed comparisons to be made between the potential resources available from different land uses in a given area. The framework was developed further in a study of land use in the Sedbergh area of the Yorkshire Dales National Park. Strategies for agriculture, forestry, recreation, landscape and wildlife conservation were the end product of this study, carried out in parallel with a local plan for the area. This book brings together the various studies carried out to date, with particular reference to those in Cumbria, and summarises the principles behind this system's approach to rural land 
use planning. It aims to show how a policy framework for rural Britain might be constructed using examples developed in Cumbria.

The usefulness of these methods has been recognised by other local authorities who have initiated similar studies of their own areas, eg Gwynedd County
Council, Lancashire County Council, and the Yorkshire Dales National Park Authority. The Institute of Terrestrial Ecology has taken the initiative in extrapolating the work to cover the whole of England, Wales and Scotland, to provide a national framework for these area studies (Bunce 1979). 


\section{The planning background}

The Town and Country Planning Act 1947 introduced a comprehensive system of land use planning involving the control of development by reference to a development plan. The statutory basis for local authority planning now rests in the Town and Country Planning Act 1971. Part II as amended by the Town and Country Planning (Amendment) Act 1972 and the Local Government Act 1972. The principal document for basic information about the system, and advice on it, is a Department of the Environment Circular (Department of the Environment 1979). The system calls for a broad and open consideration of planning problems, taking account of physical, economic and social aspects, and allows authorities to adopt a flexible approach to the way they treat and present the contents of their plans. It rests on a framework of structure and local plans for each county.

The structure plan has 3 main functions. First, it is to state and justify the county planning authority's policies and general proposals for the development and other use of land; it is restricted to matters which either affect the whole or a substantial part of the structure plan area or influence the development of the area in a significant way, or are proposals subject to statutory approval by the Secretary of State. Second, it is to interpret economic and social, national and regional policies in terms of physical and environmental planning for the area concerned. Third, it is to provide a framework for local plans, which, in turn, provide more definitive guidance for development and development control.

Local plans have 3 main functions: (1) to develop the policy and general proposals of the structure plan and to relate them to precise areas of land; $(2)$ to provide a detailed basis for development control and for coordinating the development and other use of land; and (3) to bring local and detailed planning issues before the public. There are 3 types of local plan: (a) a "district plan" relates to the whole or any part of the designated authority's area where the detailed planning matters need to be studied and set out in a comprehensive way; (b) an "action area plan" is for an area intended for comprehensive development, redevelopment and/or improvement identified in the structure plan and commenced within 10 years of its submission; (c) a "subject plan" enables detailed treatment to be given to a particular description of development or land use.

This statutory basis for planning policies is complemented by other plans and policies followed by other organisations. National Park plans, for instance, are not development plans, but are meant to co-ordinate the management of fairly large areas of countryside for recreation and conservation purposes. Neither agriculture nor forestry operations are "development" under the Town and Country Planning legislation, and the planning of these major land uses is left mainly in the hands of landowners and occupiers and their advisors in the Ministry of Agriculture and Forestry Commission.

The Countryside Review Committee (1976) considered that this sectional approach was less and less appropriate to the needs of the countryside, and that it is not enough to focus on these factors separately, without regard to their interactions. It concluded that the continued multiple use of land is, and must remain, a central concept of rural policy, with a redefinition of conservation; that conservation represents an ethic, based on respect for the natural resources of the countryside; and that it should not necessarily be opposed to change, but should seek to minimise unavoidable losses and maximise compensating gains. A consensus approach to rural land use should be developed, with the use of essentially administrative techniques to achieve this consensus, rather than the extension of statutory controls. Such an approach needs a framework within which to operate and which allows agreed priorities and strategies to be followed.

Ecology and planning is often considered to mean the inclusion of nature conservation considerations in the planning process. The Nature Conservancy Council (NCC) is recognised as the government body for local authorities to contact on these matters. Its functions are the establishment, maintenance and management of nature reserves in Great Britain, the provision of advice for Ministers on the development and implementation of policies for or affecting nature conservation, the provision of advice and the dissemination of knowledge about nature conservation and the commissioning or support of relevant research.

Full account of nature conservation is expected to be taken by local planning authorities in drawing up structure and local plans, and in considering individual planning applications (Department of the Environment 1974, 1977). Particular emphasis is laid on Sites of Special Scientific Interest (SSSI) designated by the NCC under Section 23 of the National Parks and Access to the Countryside Act 1949. The Town and Country Planning General Development Order 1977 (sub paragraphs $15(\mathrm{i})(\mathrm{g})$ and $15(5)$ ) states that planning authorities must consult the NCC before granting permission for the development of land in an SSSI and that they may not determine any application to develop such a site within 14 days of notifying the NCC of any such application. Similar importance is attached to sites identified by Ratcliffe (1977), who lists the sites of highest national and international importance for wildlife conservation. 
The nature conservation importance of individual sites is only one aspect of the conservation of natural beauty. This wider interpretation is exemplified in Section II of the Countryside Act 1968 which states that: "In the exercise of their functions relating to land under any enactment every. Minister, government department and public body shali have regard to the desirability of conserving the natural beauty and amenity of the countryside". Section 49(4) states that "the conservation of the natural beauty of an area shall be construed as including references to the conservation of its flora, fauna, and geological and physiographical features".

The Protection of Birds Acts 1954-67 (which cover all birds), the Deer Act 1963, the Conservation of Seals Act 1970, the Badgers Act 1973 and the Conservation of Wild Creatures and Wild Plants Act 1975 all provide a means of protecting those endangered species of wild fauna and flora which were not protected before. The last Act gives local authorities the power to publicise the Act, particularly among school children, and to institute proceedings for any offence under the Act committed within its area. This Act provides, in Section 5, safeguards for farmers and foresters, as does Section 37 of the Countryside Act 1968, aimed at non-interference with good land use practice.

These safeguards for farming and forestry emphasise the importance of these activities in providing food and timber. They are the major rural land uses and are reflected in the social and economic life of the rural community. Their interaction with nature conservation interests outside important sites is not emphasised except in special cases, eg the "Ramsar" convention on wetlands. However, both landscape and nature conservation are dependent to a large extent on the agricultural and forestry use of land, as is the value of land for informal countryside recreation. The resultant need for full co-ordination of land use and environmental policies has been accepted by government in National Parks (Department of the Environment 1976). However, rural planning, as currently practised by many local authorities, deals with rural settlement, rural transport and rural employment, rather than the rural occupations of forestry and agriculture, and the conservation and recreational values associated with them. More comprehensive planning of rural settlements cannot take place without careful consideration being given to these rural land uses and values. This relationship is particularly relevant in National Parks where the impact of these land uses on the landscape values and recreational use of the land is of considerable importance for their future development.

The methods often currently used when such considerations are being taken into account involve the identification of sites which are of importance for one reason or another. These sites constrain development to a greater or lesser extent and their location is often recorded in a map register, which may be com- puterised. Should a planning application fall within one of these sites, it is referred for comment to the most relevant organisations. The types of planning constraint in Cumbria are listed in Table 1.

Table 1 PLANNING CONSTRAINTS IN THE COUNTRYSIDE

(a) Safeguarding areas for: explosives, the United Kingdom Atomic Energy Authority, roads and minerals.

(b) Hazards: land liable to flooding, subsidence, pipeline and cables.

(c) Conservation areas: Urban conservation areas, Historic buildings, Ancient Monuments, Areas of Outstanding Natural Beauty, land subject to the Landscape Areas Special-Development Order (1950), Heritage Coasts, National Parks, Areas of Special Advertisement Control, Tree Preservation Orders, Sites of Special Scientific Interest, Local Nature Reserves, National Nature Reserves, Agricultural Land of the higher capability classes.

(d) Major landowners: National Trust, North West Water Authority, Forestry Commission.

Information on registered sites is of considerable importance when considering applications for planning permission to develop land. However, even if a site falls into one or other constraint categories, it must be surveyed, because there may be features of particular relevance to the planning application which had not been previously noted; or the circumstances may have changed and the development may be capable of being accommodated on the site despite its special character. Whilst these designations are of importance, the need for site appraisals relevant to each planning application makes them of most use in registering with the local planning authority the need for appropriate consultation with other organisations. When planning applications have ecological implications related to nature conservation, they are referred to the Nature Conservancy Council. Other ecological implications will obviously vary according to the particular development, and could involve a number of specialist disciplines available in such disparate organisations as the Water Authority and the Health and Safety Executive (Edington \& Edington 1977).

In providing a framework for decisions on individual planning applications, policy planning needs to take into account the special sites identified as constraints on development. However, these sites occupy only a small proportion of the land in each county and many planning applications fall outside them. The role of the policy planner then becomes one of defining the criteria to be adopted in assessing planning applications. The framework is provided as a set of criteria that developments have to satisfy, and the identification of areas wherein such development could take place. 
The assessment of the complex of environmental and land use data necessary for such a framework of land use and conservation priorities in a given area inevitably points to the use of numerical techniques, and eventual computer modelling based on such techniques. The ability of computers to handle large amounts of data enables more complex relationships to be considered than the usual "one to one" issues, eg farming versus forestry, and landscape conservation versus forestry, on which policies and decisions are needed. Such decisions will still need to be made, but the provision of a general theory of exploitation and conservation based on numerical methods can give a comprehensive background against which day-to-day planning decisions of various agencies can be placed.

This approach shows that ecology has a role in the planning of rural land use which is much more than simply being the provider of the information on which nature conservation values are assessed. Land use is the manipulation of ecosystems by man. He modifies them by drainage and fertiliser additions, by ploughing and reseeding or planting; more drastically, he removes them through his development of mineral resources and urban land. The contribution of ecology here is the identification of land and resource uses and of processes which are ecologically sound, which utilise resources efficiently to satisfy man's needs, and which safeguard them in perpetuity at the same time.
In the case of a county like Cumbria, current land use involves the production of softwood and hardwood timber; agricultural production in terms of meat, milk, wool and arable crops; the conservation of the landscape and recreational resource, as well as nature conservation. As an holistic science, ecology can provide a framework for comparing these differing demands on rural land. The land classification framework suggested here should be viewed alongside existing methods of evaluating land. It is intended to complement existing site-based designations as it is based on statistical probability rather than absolute certainty. This is particularly the case with nature conservation designations, as very highly valued wildlife areas, amongst a "sea" of agricultural ecosystems, are comparatively rare and may merit separate consideration.

There are 4 main stages to this method of producing a strategy for rural land use. Each of the first 3 stages can be used separately for more specific aspects of rural land use, as well as being essential steps to stage 4.

Stage 1 - the grouping of grid squares into land classes.

Stage 2 - the sample survey of grid squares from each land class.

Stage 3 - the production of alternative strategies.

Stage 4 - the evaluation of the alternative strategies.

\section{Stage 1: The grouping of grid squares into land classes}

\section{GRID SIZE}

The area of countryside being surveyed is divided into grid squares based for convenience upon the National Grid. These can be of any convenient size and depend upon the level of detail required. The Institute of Terrestrial Ecology has used a $10 \mathrm{~km} \times 10 \mathrm{~km}$ grid for a survey of land use in the uplands of England and Wales (ITE 1978). At the same time, Bunce (1979) has used a $1 \mathrm{~km}^{2}$ grid for an ecological survey of Britain. This is the same size as was used for the ecological survey of Cumbria (Bunce \& Smith 1978), although for surveys of smaller areas, such as the Solway Coast and the Arnside/Silverdale Areas of Outstanding Natural Beauty, a $\frac{1}{4} \mathrm{~km}^{2}$ grid was used. The grid size depends upon the total area being surveyed and the diversity of land form and ecosystems in it. Although uniform areas will by definition have only a few ecosystems, it can generally be assumed that the larger the grid square the more ecosystems it is likely to contain. The predicted distribution of ecological characteristics obtained from random samples of each land class will have a coarser pattern, the larger the grid size and the smaller the number of grid squares in each land class. The size of grid does not affect the estimates obtained for the total resource in the whole area.
This procedure is well illustrated by a survey of the Arnside/Silverdale AONB (Pilling et al. 1978). Two land classifications were produced for the AONB: one with a $\frac{1}{4} \mathrm{~km}^{2}$ grid, the other with a $1 \mathrm{~km}^{2}$ grid. The interrelationships between the grid squares of the 1 $\mathrm{km}^{2}$ grid were displayed on the first axis of a reciprocal averaging ordination (Hill 1973). This ordination arranges the grid squares into a sequence according to their similarities and is known as the main ordination axis. It shows a trend from saltmarsh and coastal lowlands, to alluvial and limestone lowlands, to inland limestone hills. This trend is repeated in the sequence given by the $\frac{1}{4} \mathrm{~km}^{2}$ grid. A comparison of the 2 trends represented by the main ordination axes shows a high degree of correlation (Figure 1). This correlation is repeated if the coastal and saltmarsh grid squares are removed from the analysis (Figure 2), with a significant correlation coefficient $(r=0.674, P<0.001)$ between the 2 grid sizes. The total vegetation resource was estimated from a random sample of grid squares from each land class. Twenty-eight vegetation types were identified in woodland, leys and pasture on deep soils, permanent pasture and saltmarsh habitats. The estimates of the total vegetation resource in the AONB are very similar whichever scale of land classification 


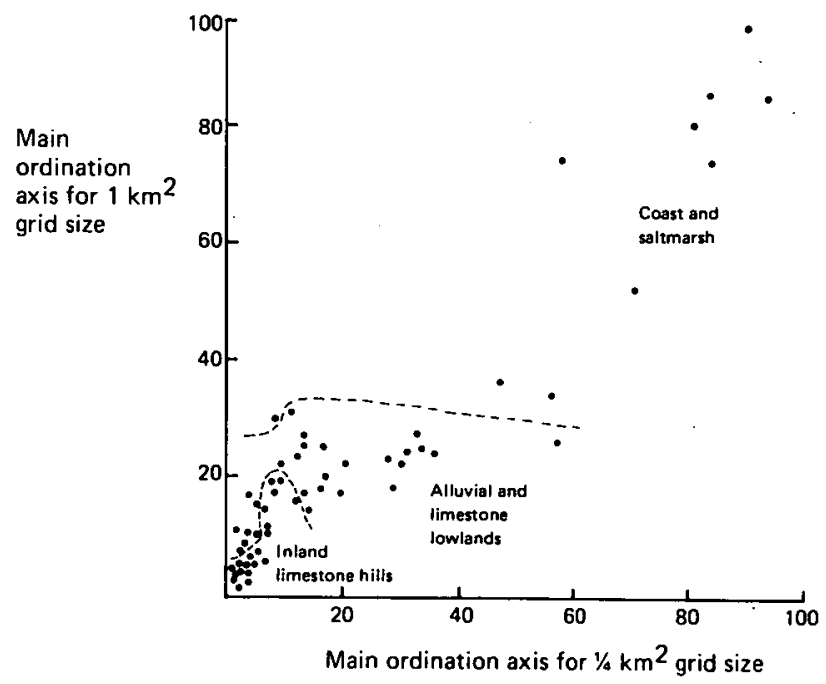

Figure 1 A comparison between 2 grid sizes for 2 land classifications of the Arnside/Silverdale AONB: a comparison utilising all land classes

The 2 axes of this graph are the main trends in the analyses of map characteristics at different scales, identified by numerical methods (Hill 1973). The essential point is that the further apart that 2 grid squares are along each axis then the more dissimilar they are. The main divisions of these trends into land classes are given to help identify them

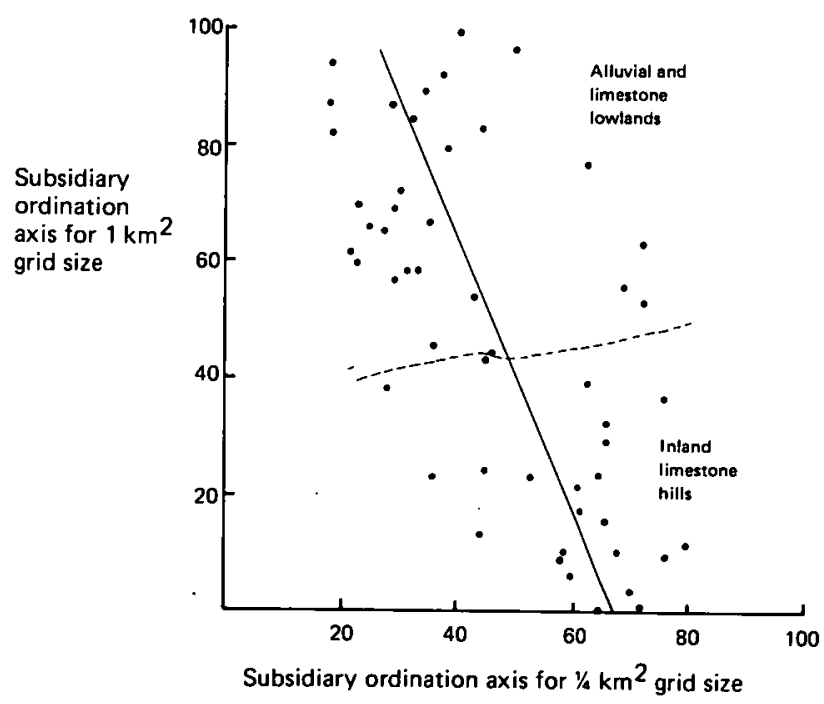

Figure 2 A comparison between 2 grid sizes for 2 land classifications of the Arnside/Silverdale AONB: a comparison between the inland land classes

grid is used (Table 2). The scale chosen must, therefore, depend upon the level of detail required in the predicted distribution patterns and upon the resources available to carry out the classification and subsequent field survey. A large grid means less grid squares and may mean a reduction in the number of land classes. In the Arnside/Silverdale example, the $\frac{1}{4}$ $\mathrm{km}^{2}$ scale had 16 land classes, and the $1 \mathrm{~km}^{2}$ scale had 8 land classes.

\section{THE CHOICE OF MAP ATTRIBUTES}

The grouping of grid squares into land classes is based upon the data that can be abstracted from Ordnance
Table 2 A COMPARISON OF THE ESTIMATED VEGETATION RESOURCE IN THE ARNSIDE/SILVERDALE AONB BASED ON 2 GRID SCALES

\begin{tabular}{|c|c|c|c|}
\hline \multirow[t]{2}{*}{ Vegetation type* } & & \multicolumn{2}{|c|}{ Predicted frequency $(\%)$} \\
\hline & & $\frac{1}{4} \mathrm{~km}^{2}$ grid & $1 \mathrm{~km}^{2}$ grid \\
\hline & 19 & 7.8 & 7.8 \\
\hline Woodland & 18 & 10.0 & 10.6 \\
\hline \multirow[t]{2}{*}{ types } & 21 & 6.0 & 6.2 \\
\hline & 20 & 5.2 & 5.1 \\
\hline \multirow{2}{*}{1} & 16 & 1.7 & 1.3 \\
\hline & 14 & 2.5 & 3.2 \\
\hline Ley and & 13 & 7.3 & 5.7 \\
\hline pasture & 15 & 3.2 & 2.2 \\
\hline types on & 12 & 2.0 & 3.7 \\
\hline \multirow[t]{6}{*}{ deep soils } & 9 & 3.6 & 2.6 \\
\hline & 10 & 4.0 & 3.1 \\
\hline & 11 & 3.4 & 3.3 \\
\hline & 2 & 5.4 & 5.1 \\
\hline & 5 & 3.3 & 2.4 \\
\hline & 3 & 4.2 & 4.7 \\
\hline Permanent & 8 & 0.5 & 0.4 \\
\hline pasture & 1 & 6.5 & 7.2 \\
\hline \multirow[t]{6}{*}{ types } & 6 & 2.0 & 1.8 \\
\hline & 4 & 2.8 & 3.1 \\
\hline & 17 & 1.6 & 2.8 \\
\hline & 7 & 1.0 & 1.8 \\
\hline & 28 & 1.2 & 1.7 \\
\hline & 27 & 0.9 & 0.8 \\
\hline Saltmarsh & 26 & 2.5 & 3.2 \\
\hline \multirow[t]{4}{*}{ types } & 23 & 2.2 & 2.8 \\
\hline & 24 & 2.1 & 2.2 \\
\hline & 22 & 4.4 & 3.2 \\
\hline & 25 & 2.1 & 2.0 \\
\hline
\end{tabular}

*The vegetation types were derived by indicator species analysis (Hill et al. 1975) of 324 plant species present in 228 sample plots, from $57 \frac{1}{4} \mathrm{~km}^{2}$ grid squares

Survey maps, geological and climatological maps. The map scales used to date have varied and depend upon the maps available, the size of the grid square and the total area being surveyed. The assumption underlying the use of map data is that the complex of map attributes within a grid square interact together to form the land class. The $1 \mathrm{~km}^{2}$ grid land classification of Cumbria showed that these map attributes relate to the 3 main determinants of land form, ie geology, topography and land use. It is the interaction between these 3 factors that determines the land class.

Clear-cut interpretation of land classes depends upon the map attribute data used to characterise them. The variables most closely related to geology, topography and land use are the most important ones to include. It is only at the national scale that climatological data have proved to be useful in identifying land classes. At the sub-regional and county scale they are so closely interrelated and dependent upon topography that they can dominate the land class groupings and confuse the interpretation. 
Initially, the map data used were not restricted to what were thought to be the most suitable. The $1 \mathrm{~km}^{2}$ grid land classification for Cumbria used all the attributes that could be found on maps that covered the whole of the county, ie the one inch scale Ordnance Survey maps and the one inch scale solid geology maps of the Geological Survey. The presence or absence of 186 map attributes was recorded (Table 3), and it was left to the classification method to sort out the most important in identifying the land classes. Subsequent surveys were modified in the light of this experience. A $\frac{1}{4} \mathrm{~km}^{2}$ land classification of the Sedbergh area of the Yorkshire Dales National Park only recorded 44 map attributes, and only 15 of these were presence/ absence attributes (Table 4). The remainder were measures of area or length. These were used as presence/absence data only after subdividing the range into 4 equal parts. For instance, if the length of minor roads in a grid square was $0.11 \mathrm{~km}$ then, from Table 4 . attribute 17 would have been recorded as being present in that particular grid square.

Table 3 CHARACTERISTICS USED IN THE CUMBRIA LAND CLASSIFICATION

\begin{tabular}{|c|c|c|c|c|c|c|c|}
\hline 1 & 'A' Road & 45 & Hamlet & 97 & Tarn depth $26-50 \mathrm{ft}$ & 149 & Old canal \\
\hline 2 & 'B' Road & 46 & Village & 98 & Tarn depth $51-75 \mathrm{ft}$ & 150 & Giants' graves \\
\hline 3 & Yellow road & 47 & Town & 99 & Tarn depth 76-100 ft & 151 & Thunderstone \\
\hline 4 & White road & 48 & Post Office & 100 & Tarn depth $101-125 \mathrm{ft}$ & 152 & Tower \\
\hline 5 & Unfenced road & 49 & Public house & 101 & Tarn depth $126-150 \mathrm{ft}$ & 153 & Coastguard lookout \\
\hline 6 & Station & 50 & $\ln n$ & 102 & Tarn depth $151-175 \mathrm{ft}$ & 154 & Dock \\
\hline 7 & Railway (in use) & 51 & Hoteì & 103 & Tarn depth $176-200 \mathrm{ft}$ & 155 & Lifeboat station \\
\hline 8 & Railway (disused) & 52 & Telephone & 104 & Tarn depth $201-225 \mathrm{ft}$ & 156 & River mouth \\
\hline 9 & Footpath & 53 & Caravan site & 105 & Tarn depth $226-250 \mathrm{ft}$ & 157 & Aerial ropeway \\
\hline 10 & Bridleway & 54 & Camp site & 106 & Tarn size 10 acres & 158 & Sand and shingle \\
\hline 11 & River & 55 & Church with steeple & 107 & Tarn size $10-50$ acres & 159 & Sand and mud \\
\hline 12 & Stream & 56 & Church with tower & 108 & Tarn size $51-100$ acres & 160 & Airfield \\
\hline 13 & Weir & 57 & Church with neither & 109 & Tarn size $101-500$ acres & 161 & Dunes \\
\hline 14 & Road used as public path & 58 & Thwaite & 110 & Tarn size 500 acres & 162 & Beacon \\
\hline 15 & Intertidal water & 59 & Mountain rescue post & 111 & Golf course & 163 & Basin peat, alluvium. \\
\hline 16 & Bridge over railway & 60 & Climbing hut & 112 & Cliff & & river gravels \\
\hline 17. & Waterfall & 61 & Youth hostel & 113 & Slope & 164 & Kirklinton, St. Bees sand- \\
\hline 18 & Bridge over water & 62 & Shooting box & 114 & Embankment & & stone plus St. Bees \\
\hline 19 & Steep hill (road) & 63 & Hospital & 115 & Cutting & & shales \\
\hline 20 & Land between $0-249 \mathrm{ft}$ & $64^{\circ}$ & Cemetery & 116 & Television and radio mast & 165 & Penrith sandstone plus \\
\hline 21 & Land between $250-499 \mathrm{ft}$ & 65 & Club house & 117 & Enclosures & & brochram \\
\hline 22 & Land between $500-749 \mathrm{ft}$ & 66 & Town hall & 118 & Copse & 166 & Upper coal measures \\
\hline 23 & Land between $750-999 \mathrm{ft}$ & 67 & Public convenience & 119 & Sheep fold & 167 & Middle and lower coal \\
\hline \multirow[t]{2}{*}{24} & Land between & 68 & Pylons & 120 & Adjacent to town square & & measures \\
\hline & $1000-1249 \mathrm{ft}$ & 69 & Pipe line & 121 & Railway tunnel & 168 & Millstone grit \\
\hline \multirow[t]{2}{*}{25} & Land between & 70 & Mile-stone & 122 & Footbridge over water & 169 & Limestone groups \\
\hline & $1250-1499 \mathrm{ft}$ & 71 & Mile-post & 123 & Moat & 170 & Basement beds \\
\hline \multirow[t]{2}{*}{26} & Land between & 72 & Information point & 124 & Windpump & & (conglomerate etc) \\
\hline & $1500-1749 \mathrm{ft}$ & 73 & Earthworks & 125 & Cave & 171 & Bannisdale slates, \\
\hline \multirow[t]{2}{*}{27} & Land between & 74 & Stone circle & 126 & Railway bridge over water & & Coniston flags \\
\hline & $1750-1999 \mathrm{ft}$ & 75 & Cairn & 127 & Firing range & & Stockdale shales \\
\hline \multirow[t]{2}{*}{28} & Land between & 76 & Settlement & 128 & Parking place & 172 & Coniston limestone \\
\hline & $2000-2249 \mathrm{ft}$ & 77 & Field system & 129 & Roundabout & 173 & Skiddaw slates \\
\hline \multirow[t]{2}{*}{29} & Land between & 78 & Castle & 130 & Road bridge over road & 174 & Basaltic lavas \\
\hline & $2250-2499 \mathrm{ft}$ & 79 & Roman castle/house & 131 & Road tunnel & & (carboniferous) \\
\hline \multirow[t]{2}{*}{30} & Land between & 80 & Roman road & 132 & Works & 175 & Andesites, rhyolites and \\
\hline & $2500-2749 \mathrm{ft}$ & 81 & Standing stone & 133 & Viaduct & & tuffs (Borrowdale \\
\hline \multirow[t]{2}{*}{31} & Land between & 82 & Monument & 134 & Ford & & volcanic series) \\
\hline & $2750-2999 \mathrm{ft}$ & 83 & Tumulus & 135 & Open pit & 176 & Gabbro \\
\hline 32 & Land above $3000 \mathrm{ft}$ & 84 & Religious monument & 136 & Ancient monument & 177 & Dolorite, diorite and diabase \\
\hline 33 & Aspect North & 85 & Quarry & 137 & Pier & & etc. of Isle of Man \\
\hline 34 & Aspect South & 86 & Mine & 138 & Ferry & 178 & Quartz - felsite \\
\hline 35 & Aspect East & 87 & Wood-conifer & 139 & Mineral line etc. & 179 & Granophyre \\
\hline 36 & Aspect West & 88 & Hardwood & 140 & Beacon & 180 & Granite \\
\hline 37 & Viewpoint & 89 & Mixed wood & 141 & Ski hut & 181 & Blown sand \\
\hline 38 & Island & 90 & Marsh & 142 & Motorway & 182 & Fell sandstone \\
\hline 39 & Spot height & 91 & Parkland & 143 & Abbey & 183 & Lower lias \\
\hline 40 & Triangulation point & 92 & Bracken/heath & 144 & Chimney & 184 & Keuper marl \\
\hline 41 & Scree/crag & 93 & National Trust property & 145 & Hanging stone & 185 & Raised beach \\
\hline 42 & Black house & 94 & School & 146 & Boat house & 186 & Basalt and dolerite in \\
\hline 43 & Grey house & 95 & Sea & 147 & Level crossing & & sheets \\
\hline 44 & Hall & 96 & Tarn depth $0-25 \mathrm{ft}$ & 148 & Well & & \\
\hline
\end{tabular}


Table 4 MAP CHARACTERISTICS (PRESENCE/ABSENCE) USED FOR A LAND CLASSIFICATION OF THE SEDBERGH DISTRICT

\begin{tabular}{|c|c|c|c|c|c|c|c|}
\hline Map characteristic & $\begin{array}{c}\text { Minimum } \\
\text { value }\end{array}$ & $\begin{array}{l}\text { Maximum* } \\
\text { value }\end{array}$ & Code & Map characteristic & $\begin{array}{l}\text { Minimum } \\
\text { value }\end{array}$ & $\begin{array}{c}\text { Maximum } \\
\text { value }\end{array}$ & Code \\
\hline Main road & 0.20 & 0.36 & 1 & Distance to valley & 0.05 & 1.34 & 66 \\
\hline \multirow[t]{2}{*}{ (length, kilometres) } & 0.37 & 0.53 & 2 & bottom (kilometres) & 1.35 & 2.02 & 67 \\
\hline & 0.54 & 0.69 & 3 & & 2.03 & 3.01 & 68 \\
\hline$\cdot$ & 0.70 & 0.85 & 4 & & 3.02 & 4.00 & 69 \\
\hline \multirow{2}{*}{$\begin{array}{l}\text { Secondary road } \\
\text { (length, kilometres) }\end{array}$} & 0.2 & 2.4 & 5 & Railway line & 0.05 & 0.19 & 70 \\
\hline & 2.5 & 4.6 & 6 & (length, kilometres) & 0.20 & 0.32 & 71 \\
\hline \multirow[t]{2}{*}{-} & 4.7 & 6.8 & 7 & & 0.33 & 0.46 & 72 \\
\hline & 6.9 & 9.0 & 8 & & 0.47 & 0.60 & 73 \\
\hline Metalled road & 0.10 & 0.29 & 9 & Disused railway line & 0.20 & 0.31 & 74 \\
\hline \multirow{2}{*}{$\begin{array}{l}\text { less than } 4 \text { m wide } \\
\text { (length, kilometres) }\end{array}$} & 0.30 & 0.48 & 10 & (length, kilometres) & 0.32 & 0.42 & 75 \\
\hline & 0.49 & 0.66 & 11 & & 0.43 & 0.54 & 76 \\
\hline & 0.67 & 0.85 & 12 & & 0.55 & 0.65 & 77 \\
\hline Metalled road & 0.05 & 0.30 & 13 & & & . & \\
\hline \multirow{2}{*}{$\begin{array}{l}\text { more than } 4 \text { m wide } \\
\text { (length, kilometres) }\end{array}$} & 0.31 & 0.55 & 14 & Stream (length, & 0.05 & 0.55 & 78 \\
\hline & 0.56 & 0.79 & 15 & kilometres) & 0.56 & 1.05 & 79 \\
\hline Minior mad & 0.80 & 1.04 & 16 & & 1.06 & 1.55 & 80 \\
\hline \multirow{4}{*}{$\begin{array}{l}\text { Minor road } \\
\text { (length, kilometres) }\end{array}$} & 0.08 & 0.31 & 17 & & 1.56 & 2.05 & 81 \\
\hline & 0.32 & 0.56 & 18 & River (length, & 0.05 & 0.60 & 82 \\
\hline & 0.57 & 0.79 & 19 & kilometres) & 0.61 & 1.15 & 83 \\
\hline & 0.80 & 1.00 & 20 & & 1.16 & 1.70 & 84 \\
\hline \multirow{2}{*}{$\begin{array}{l}\text { Unfenced minor } \\
\text { road (length, }\end{array}$} & 0.10 & 0.23 & 21 & & 1.71 & 2.25 & 85 \\
\hline & 0.24 & 0.37 & 22 & Stream network & 1 & 2 & 86 \\
\hline kilometres! & 0.38 & 0.50 & 23 & (number of forks & 3 & 4 & 87 \\
\hline & 0.51 & 0.64 & 24 & in drainage pattern) & 5 & 5 & 88 \\
\hline Settlements & 1 & 2 & 25 & & 6 & 7 & 89 \\
\hline (area, hectare) & 3 & 3 & 26 & Lake & aḅsent - & resent & 90 \\
\hline & 4 & 4 & 27 & Woodland & 1 & 8 & 91 \\
\hline & 5 & 6 & 28 & (area, $\mathrm{m}^{2}$ ) & 9 & 16 & 92 \\
\hline Settlements & 1 & 5 & 29 & & 17 & 23 & 93 \\
\hline (number) & 9 & 10 & 30 & & 24 & 31 & 94 \\
\hline & 11 & 14 & $3 !$ & Woodland & 1 & 1 & 95 \\
\hline & 15 & 19 & 32 & (number of woods) & 2 & 2 & 96 \\
\hline Highest contour & 16 & 183 & 33 & & 3 & 3 & 97 \\
\hline (metres above OD) & 184 & 350 & 34 & & 4 & 4 & 98 \\
\hline 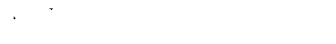 & 351 & 518 & 35 & Path & absent- & resent & 99 \\
\hline & 519 & 685 & 36 & Cliff & “ & " & 100 \\
\hline Gradient (degrees of & 0.6 & 9.8 & 37 & Quarry & $\cdot$. & . & 101 \\
\hline slope from highest & 9.9 & 19.1 & 38 & Marsh & ." & ." & 102 \\
\hline to lowest point) & 19.2 & 28.3 & 39 & Rough grassland & $\cdot$ & " & 103 \\
\hline & 28.4 & 37.6 & 40 & Motorway & ". & ", & 104 \\
\hline Length of slope & 250.0 & 382.5 & 41 & Geology - Silurian & , & . & 105 \\
\hline (metres from & 383.0 & 515.0 & 42 & Geology - Basement beds & . & , & 106 \\
\hline highest to lowest & 515.5 & 647.5 & 43 & Geology - Coniston & & & \\
\hline point) & 648.0 & 780.0 & 44 & limestone & " & ", & 107 \\
\hline Land between 0-76 m. & 1.0 & 1.0 & 45 & Geology - Carboniferous & . & & \\
\hline altitude $\left(\right.$ area, $\left.\mathrm{m}^{2}\right)$ & & & & limestone & " & . & 108 \\
\hline Land between $76-198 \mathrm{~m}$ & 1 & 10 & 46 & Geology-Millstone & . & & \\
\hline altitude (area, $\mathrm{m}^{2}$ ) & 11 & 19 & 47 & grit & " & " & 109 \\
\hline$\cdot$ & 20 & 27 & 48 & Geology - Basaltic & $\because$ & " & 110 \\
\hline . & 28 & 36 & 49 & Geology - Alluvium & ." & $\ldots$ & 111 \\
\hline Land between & 1 & 9 & 50 & Geology - Ordovician & . & . & 112 \\
\hline $198-488 m$ & 10 & 18 & 51 & Distance to ' $A$ ' road & 0.05 & 2.11 & 113 \\
\hline altitude (area, $\mathrm{m}^{2}$ ) & 19 & 27 & 52 & (kilometres) & 2.12 & 4.16 & 114 \\
\hline & 28 & 36 & 53 & & 4.17 & 6.22 & 115 \\
\hline Land between & 1 & 9 & 54 & & 6.23 & 8.28 & 116 \\
\hline $488-1189 \mathrm{~m}$ & 10 & 18 & 55 & Distance to 'B' or & 0.05 & 1.07 & 117 \\
\hline altitude (area, $\left.\mathrm{m}^{2}\right)$ & 19 & 27 & 56 & ' $\mathrm{C}$ ' class road & 1.08 & 2.08 & 118 \\
\hline & 28 & 36 & 57 & (kilometres) & 2.09 & 3.11 & 119 \\
\hline Distance to hill & 0.05 & 1.18 & 58 & & 3.12 & 4.13 & 120 \\
\hline (kilometres) & 1.19 & 2.31 & 59 & Aspect, degrees & 0 & 45 & 121 \\
\hline . & 2.32 & 3.44 & .60 & from north of main & 46 & 90 & 122 \\
\hline & 3.45 & 4.57 & 61 & slope line & 91 & 135 & 123 \\
\hline Height of nearest & 106 & 263 & 62 & & 136 & 180 & 124 \\
\hline hill (metres) & 264 & 421 & 63 & Aspect, degrees from & 0 & 45 & 125 \\
\hline & 422 & 578 & 64 & east of main slope line & 46 & 90 & 126 \\
\hline$\cdot$ & 579 & 735 & 65 & 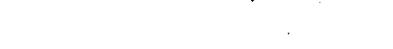 & 91 & 135 & 127 \\
\hline & & & & & 136 & 180 & 128 \\
\hline
\end{tabular}

*The 4 classes for each map characteristic were defined by dividing the range into 4 equal parts 
THE LAND CLASSIFICATION AND ITS INTERPRETATION

Indicator species analysis (Hill et al. 1975) was the cluster analysis technique used to group the grid squares into land classes on the basis of their recorded map attributes. As a cluster analysis technique it has been found to provide natural groupings of samples characterised by presence/absence data. It successively subdivides the data set into $2,4,8,16$, etc, classes based on the median division of a single axis ordination. The problem of excessive subdivision of some classes is not crucial to its use in this context. The land classes do not have any existence in their own right. On the ground they merely represent collections of ecosystems or land forms. As sample strata, they may prove to be very similar in some respects but different in others. For example, 6 of the land classes in the Sedbergh classification were almost identical in their agricultural potential. However, the range of soil types differed considerably between them. The stopping point for the subdivision in most of the land classifications produced within Cumbria to date has been the 16 class level.

One benefit given by indicator species analysis is that it identifies the most important map attributes responsible for each division in the analysis. Therefore, it produces an efficient key to the classification and enables grid squares not previously surveyed to be allocated to their most appropriate land class. This enables greater efficiency in the production of the land classes by using a sample of the grid squares to derive the key. The remaining grid squares in the area need only have the "indicator" attributes measured in order for them to be properly allocated. The usual procedure has been to sample the centre square from each group of 9 in a grid across the survey area. All attributes are measured in these squares to produce the land classification; in the case of the Cumbria survey, this was 186 attributes measured in 789 grid squares. The indicator species analysis identified 41 for use in the key, whereby the remaining $6311 \mathrm{~km}^{2}$ were allocated to a land class. This enabled the time spent in recording the relevant map attributes to be cut to about a quarter. One disbenefit of using the key is the necessity for. 2 people to use it, ie to repeat the allocation of each square. The tedium of this particular job resulted in a $15 \%$ misclassification rate in the more diverse areas of Cumbria, when only one person used the key to classify the remaining $6311 \mathrm{~km}^{2}$. The dichotomous key produced for Cumbria shows the form that these dendrograms take (Figure 3 ).

The direct interpretation of the land classes depends upon the main criteria selected by the indicator species analysis. For Cumbria, these were a mix of geological, topographical and land use attributes reflecting the main trends in the county. The Solway coast $\frac{1}{4} \mathrm{~km}^{2}$ land classes are primarily interpreted by their geological and land use attributes: topography was not as important in this lowland coastal area. In the Sedbergh area, the land classification is dominated by topographical attributes, with land use only differentiating between land classes in the valley bottoms of this primarily upland area. The $\frac{1}{4} \mathrm{~km}^{2}$ land classification of the Arnside/Silverdale AONB omitted geological data and, whilst the overall trend from flat alluvial land to limestone hills was easily interpretable, the detailed differences between land classes were not easily discerned from the map attributes alone.

The distribution of the land classes and the important map attributes in each land class assist in understanding what each one represents. This is well illustrated in the land classification of Cumbria, where main differences between upland (land classes 9-16) and lowland (land classes 1-8) are obvious (Figure 4). The Eden Valley (land class 2) (Plate 1) and coastal and Solway lowlands (land classes 1, 5,6 and 8) (Plate 2) are separated from the central Lake District (land classes 15, 16) (Plate 3) and Pennine Fells (land classes 13,14$)$ by altitudinal and geological map attributes, with the latter upland areas separated from one another on geological and slope features. The most important attributes for each land class are those which are constant, ie occur with a frequency of between $80 \%$ and $100 \%$, and those which are characteristic, ie are particularly associated with one land class rather than with others. Characteristic attributes are those which have the highest chi-square values, calculated from the assumption that the expected frequency in a land class would be the same in all land classes if there was no association of an attribute with a particular land class (Table 5). The differences between the intermediate land classes, eg 9-12, are more subtle and required field survey to aid identification. Some of the field characteristics were later evident in the map features, eg the presence of unfenced roads and field barns (black houses) in land class 10 (Plate 4), and their absence from land class 9 indicated that one could expect the former to contain permanent pasture, or inbye land, in these generally marginal upland classes.

A knowledge of the environmental features represented by map attributes can, therefore, enable a considerable degree of understanding to be gained direct from the land classification. The land classification itself is also particularly valuable in defining major boundaries between land forms, albeit on a grid basis. This avoids the problem of boundary definition when there is no sharp division, but rather a gradation, from one type of area to another. 


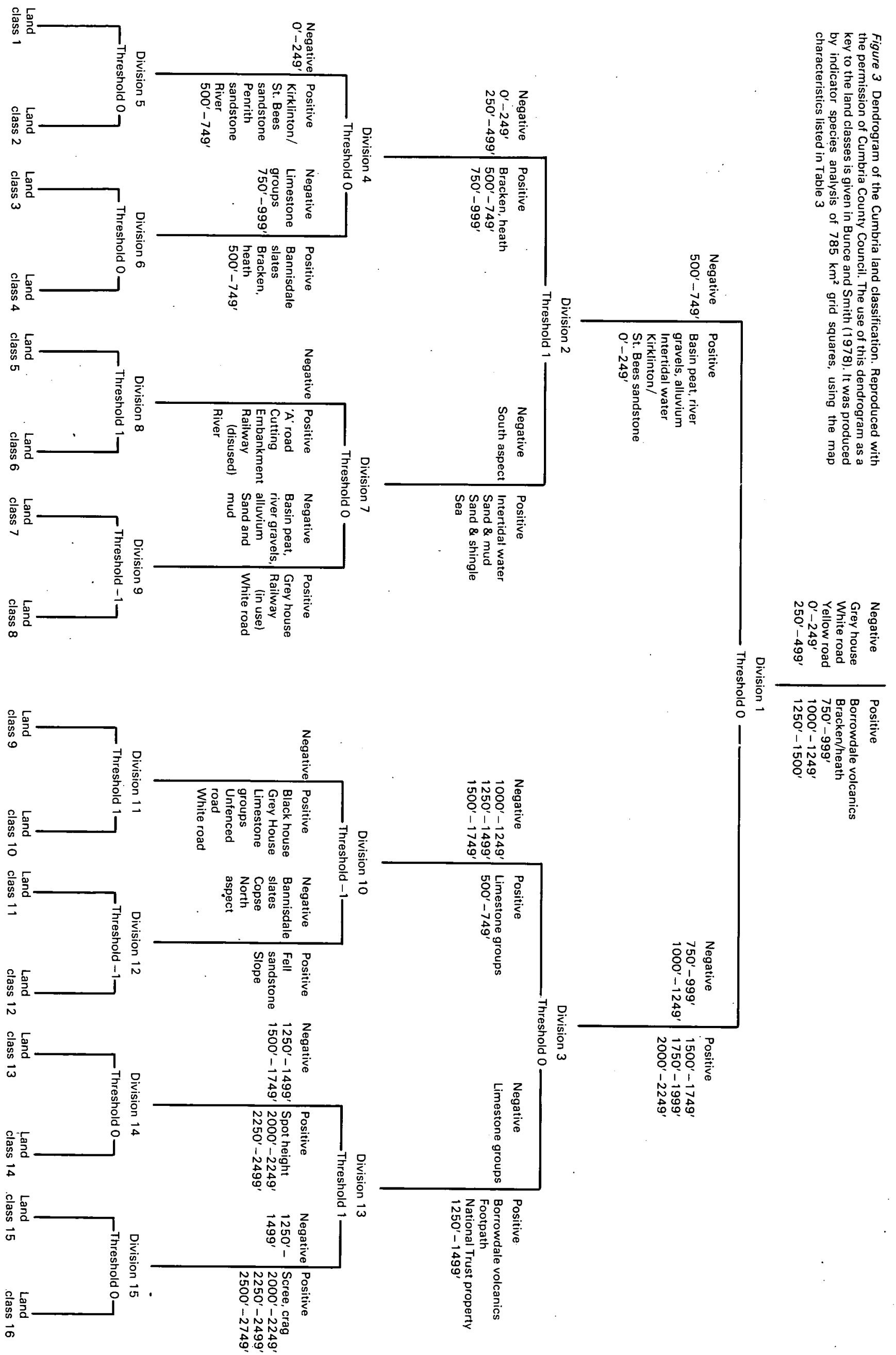




\section{Distribution of land classes}

Figure 4 Distribution of the Cumbrian land classes.

Reproduced with the permission of Cumbria County Council
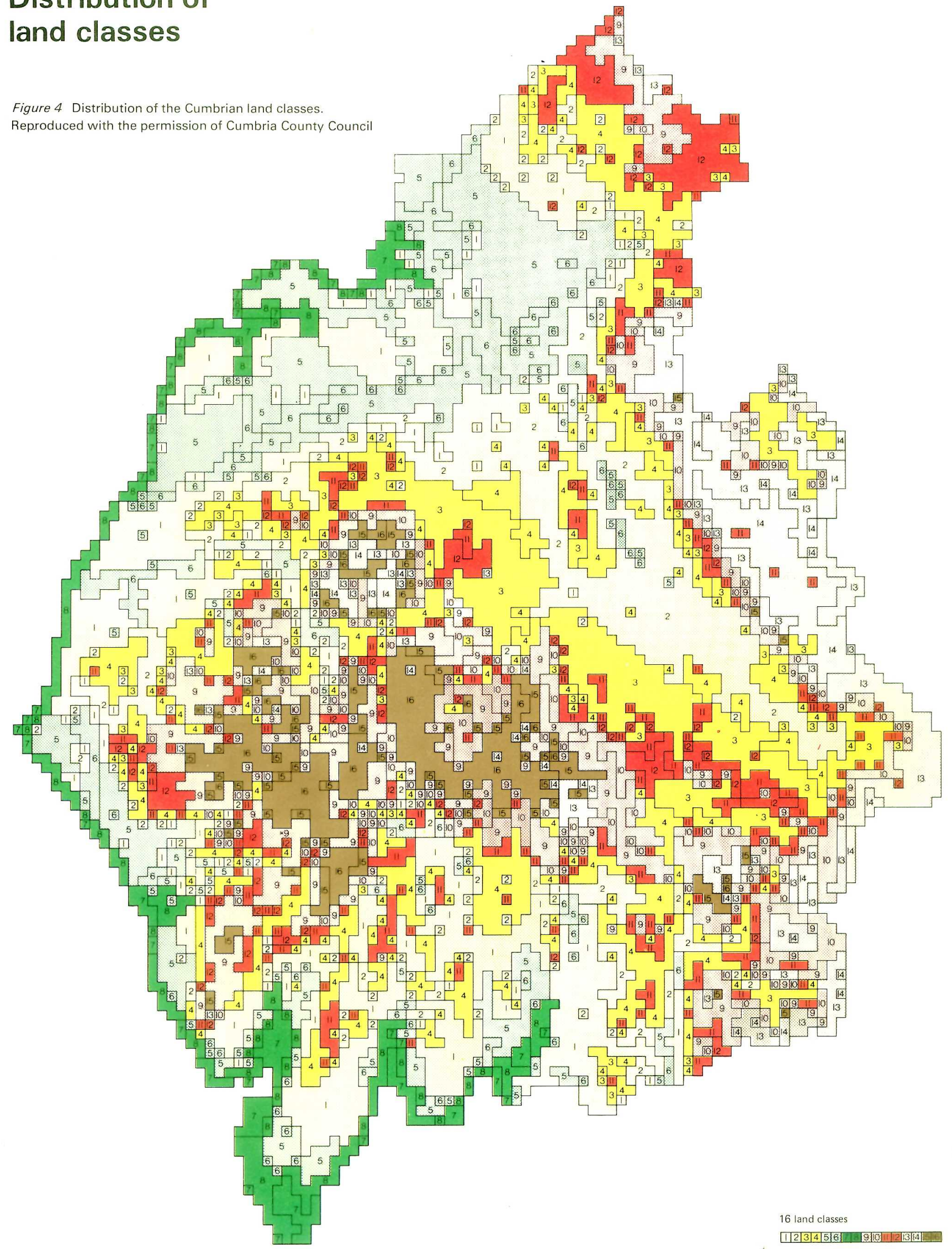
Table 5 MAP CHARACTERISTICS OF THE 16 CUMBRIAN.LAND CLASSES

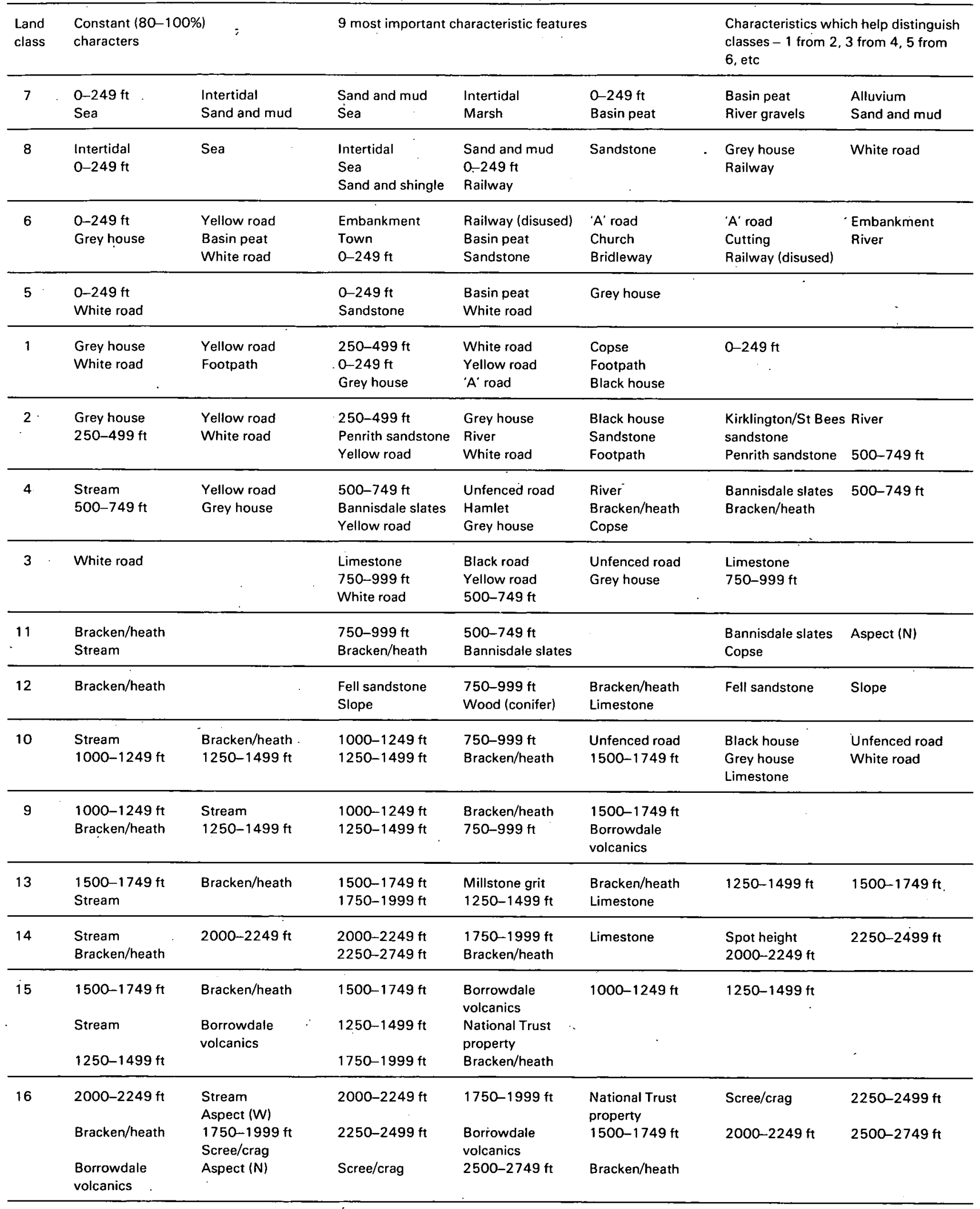




\section{Stage 2: The sample survey of grid squares from each land class}

\section{TYPES OF DATA AND SAMPLE SIZE}

The further interpretation and characterisation of the land classes need data collected from the field. Data that are dependent upon the same basic parameters that influence the variability of the land classes will show distinct correlations with the land classes. These basic parameters are the geological, topographic, climatic and land use factors which are the major determinants of vegetation, soils, landscape, and agricultural and forestry potential.

If a sampled feature is not dependent upon these basic parameters, then the results will show an even spread over the land classes. The national or regional estimate of the total amount of that feature will be as useful as the estimates for features which are closely correlated with the land classes, although the pattern of distribution of these features may not be as interesting to the surveyors.

Before using these data to further characterise the land classes, it is worth remembering that the land classes do not have any existence in their own right. They are abstractions arbitrarily defined on a grid system and used primarily as strata for surveying a region. They will contain a range of ecosystems, soil types and landscape types and should not be expected to be uniform in composition. They are not analogous to the more conventional categories into which the countryside is divided, eg woodland or grassland. Whilst they are assigned mean values for given characteristics in order that predictive maps may be developed, any values or assessments of potential should be related to their component parts. For instance, "high" conservation value for a woodland is not the same thing as a "high" conservation value for a land class. In the first instance, the high value is given after comparing one woodland with another (Ratcliffe 1977). The analogous situation with a land class would require a survey and evaluation of the conservation value of all the grid squares in that land class in order to find the "best" example of that land class, which ignores the fact that the land classes are a sampling strata and would need a complete survey of the area in question.

The selection of squares for detailed sampling is done at random. The squares in a land class are numbered sequentially and random number tables (Fisher \& Yates 1943) are used to select an appropriate number. Webster (1977) gives a binomial method for calculating the number of samples required to achieve a given level of accuracy. This method requires an initial survey of 3 or 4 squares to define the variability.

The detailed methods used for the field survey depend upon what is being measured. However, for all characteristics, a choice has to be made between point sampling (Bunce \& Shaw 1973) and complete surveying within the square. This affects the number of grid squares that need to be surveyed. As the number of point samples increases, the frequency of each characteristic measured stabilises at the mean value. $A$ survey of the main soil types in each of the 16 Cumbria land classes illustrates this for point samples. Eight points were randomly placed within 10 grid squares from land class 4 . As the number of samples increases, the mean percentage frequency stabilised with little change beyond 66 sample points (Figure 5). The sample size necessary to give sample means that would be within $10 \%$ of the population mean, $90 \%$ of

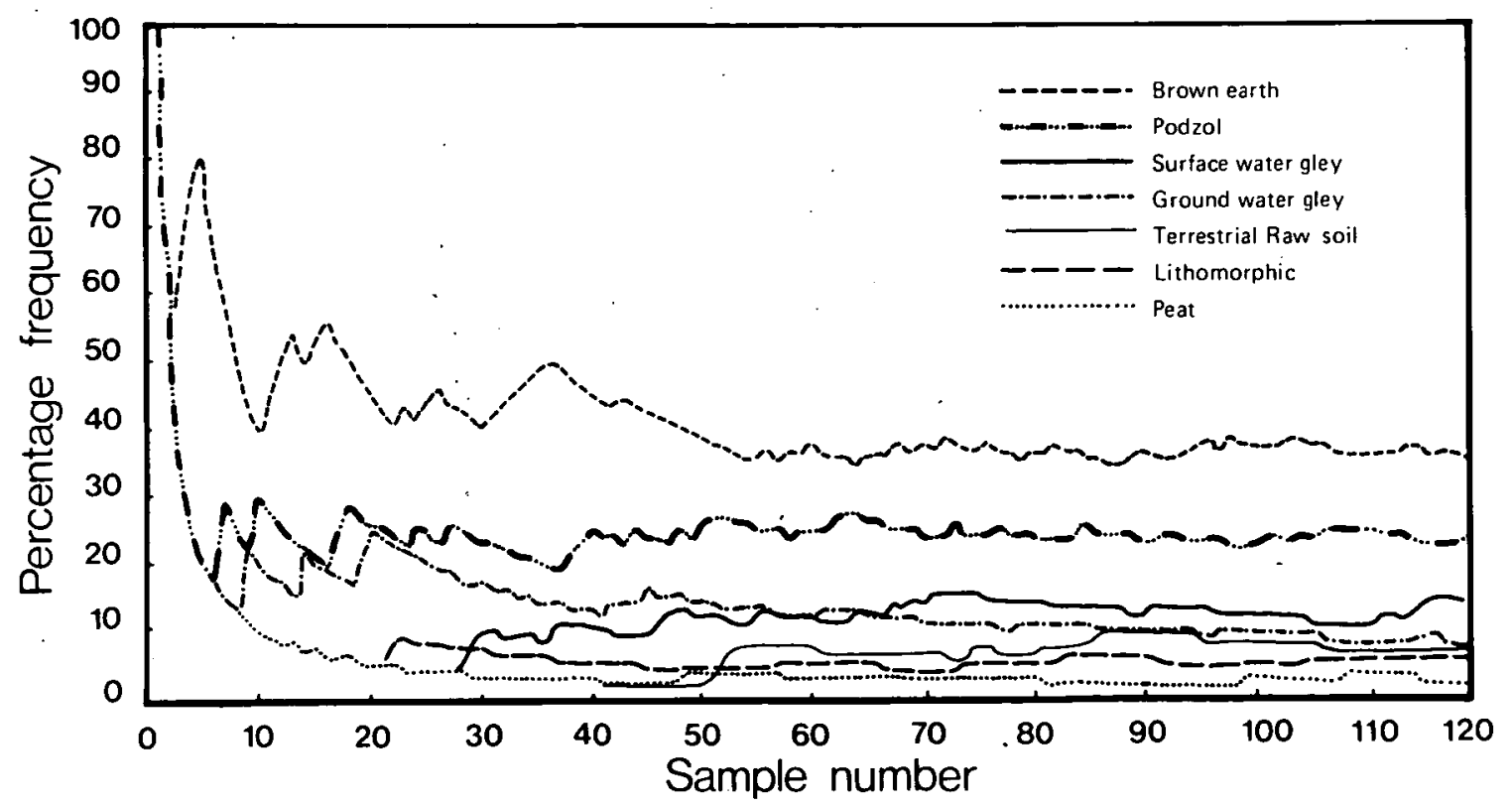

Figure 5 Frequency of the main soil types in Cumbrian land class 4

Copyright: British Association of Nature Conservationists. Reprinted from ECOS-A Review of Conservation 


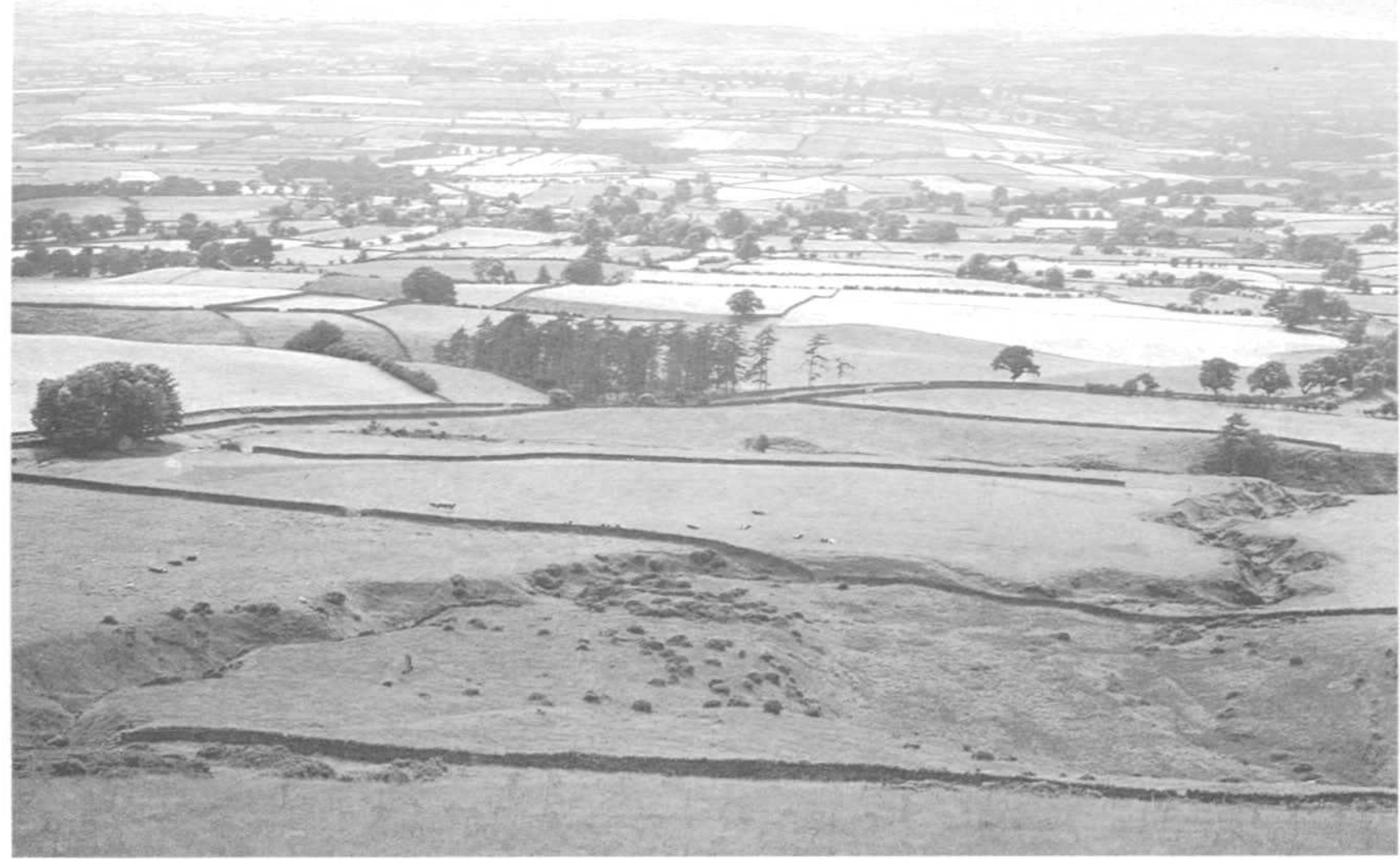

Plate 1 Eden Valley. Cumbrian land class 2 (Photograph - Ken Leech)

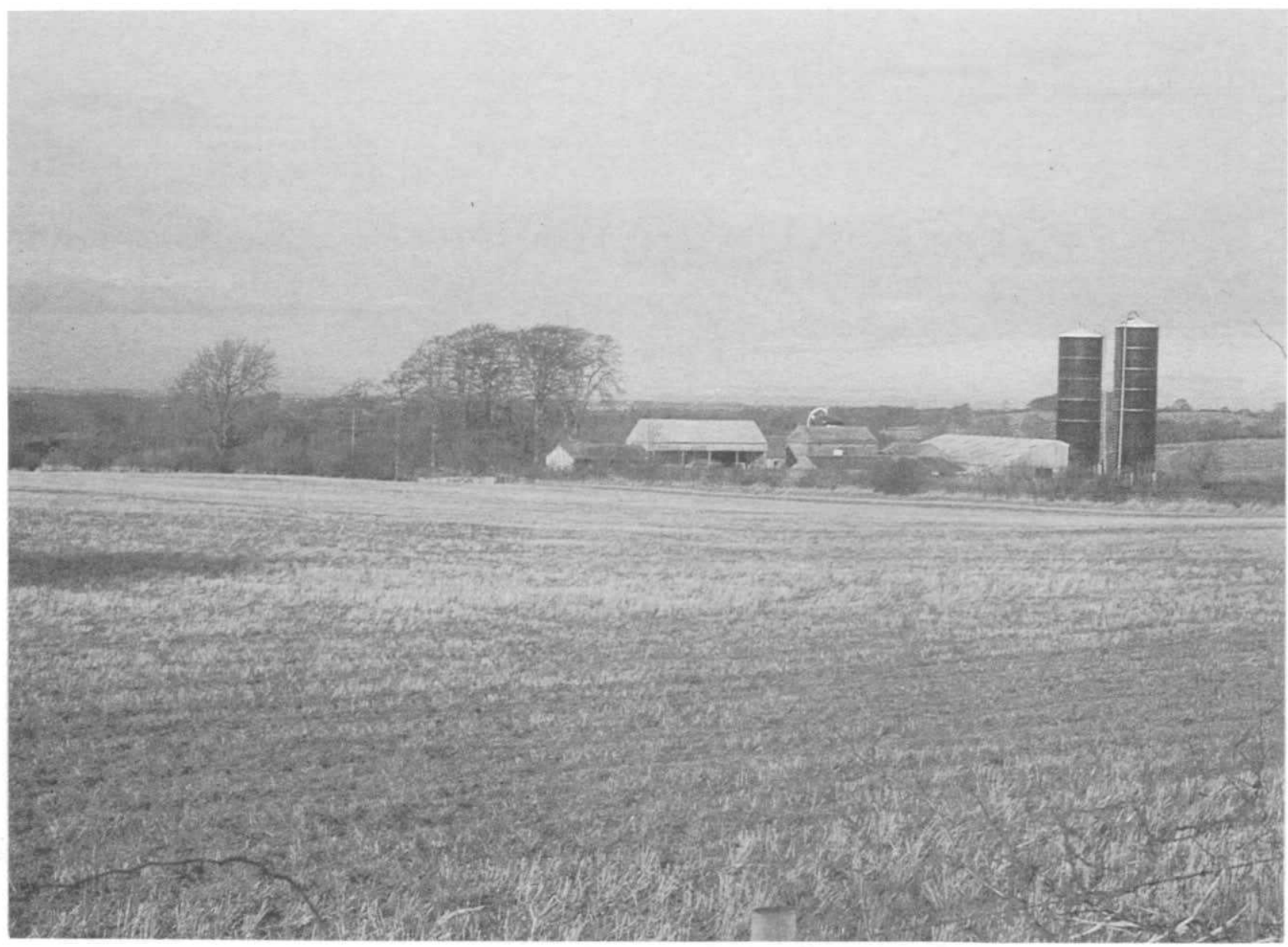

Plate 2 Barley field at Raughton Head. Cumbrian land class 5 (Photograph-Roger Smith) 


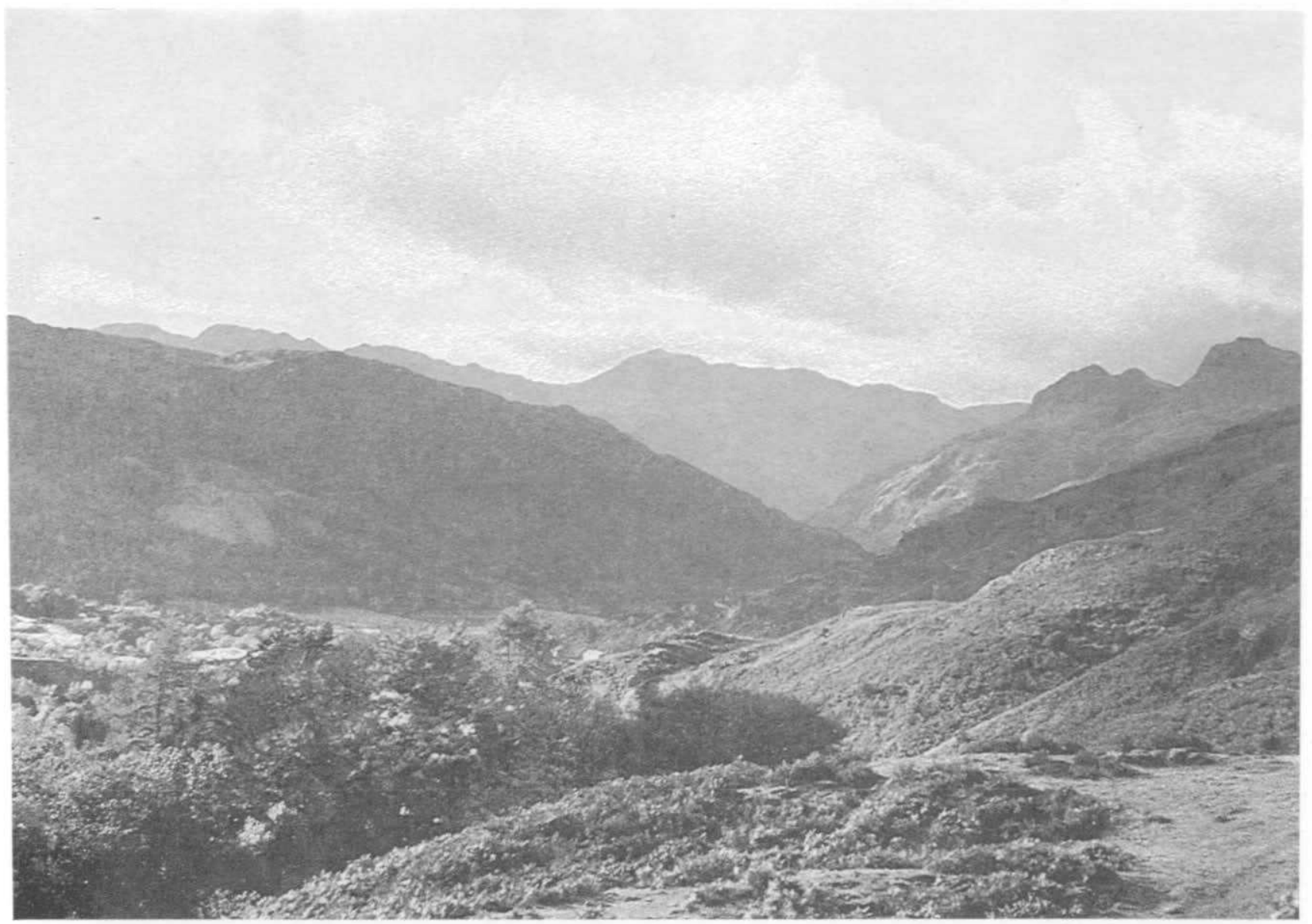

Plate 3 Langdale Pikes, Central Lake District. Cumbrian land classes 15 \& 16 (Photograph-Colin Armitstead)

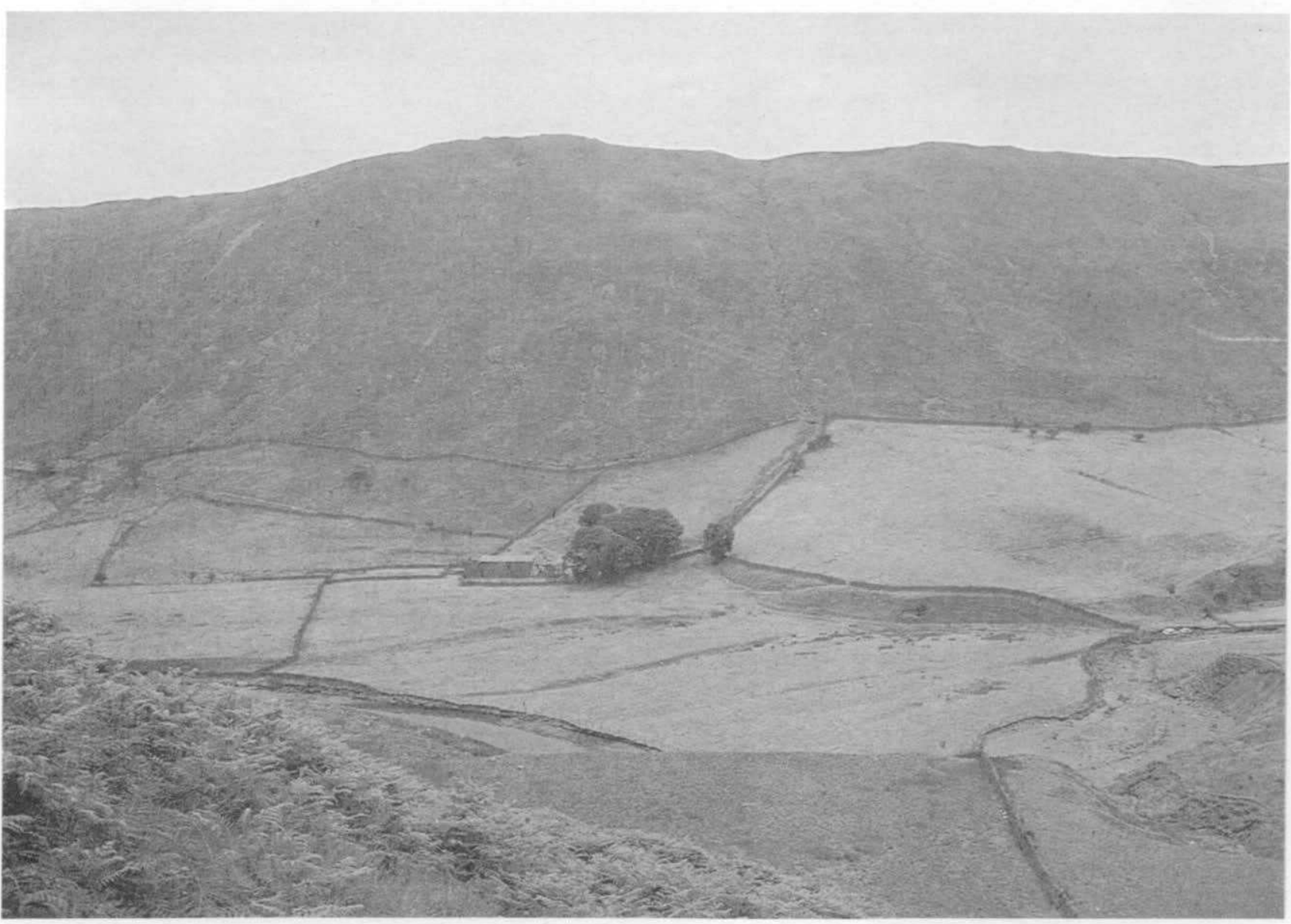

Plate 4 Inbye land and rough grazing at Low Borrowdale Farm, Borrowdale. Cumbrian land class 10 (Photograph-Roger Smith) 


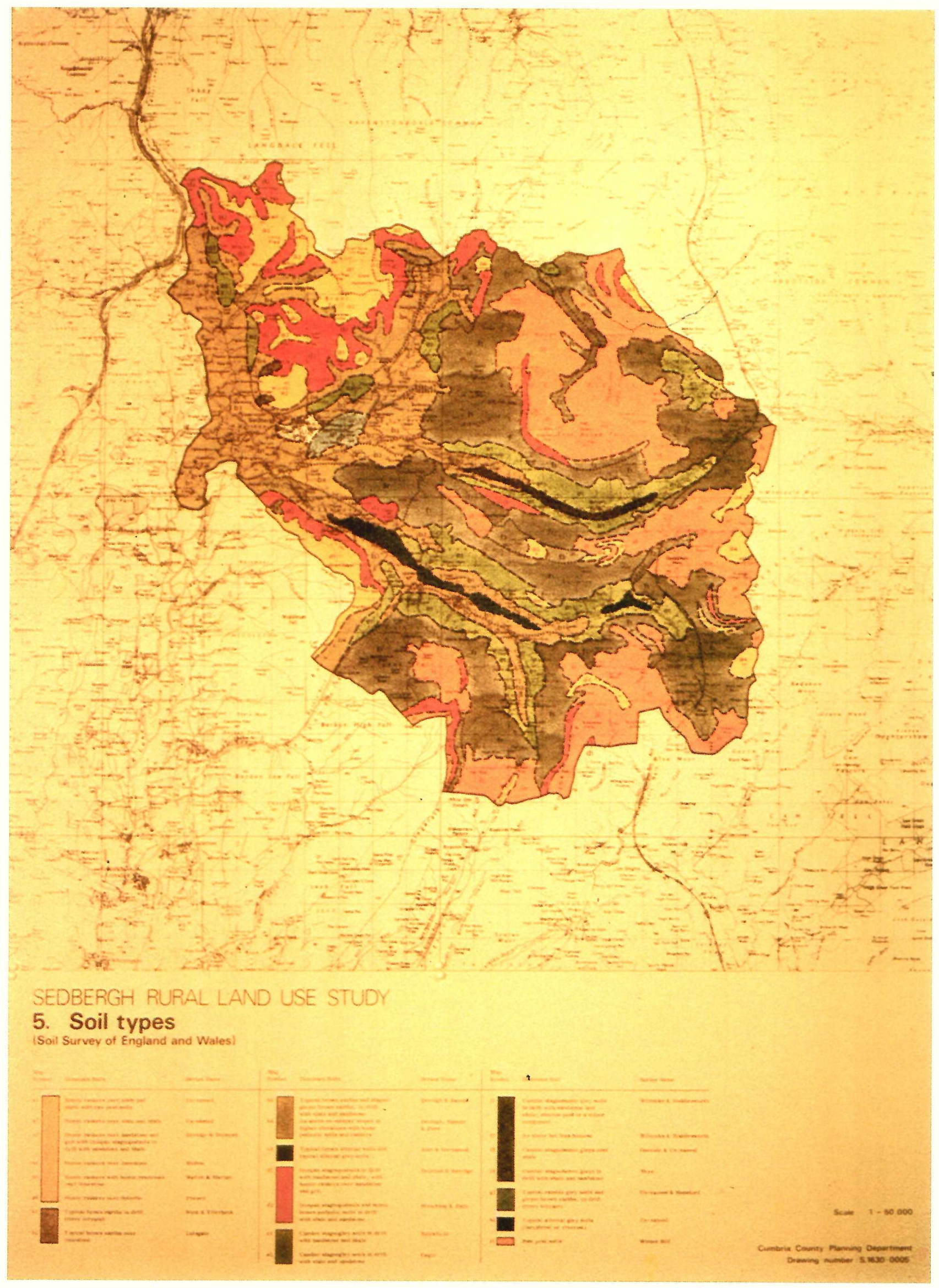


Plate 6 Land use capability classification map, Sedbergh area (based on information from the Soil Survey of England and Wales)

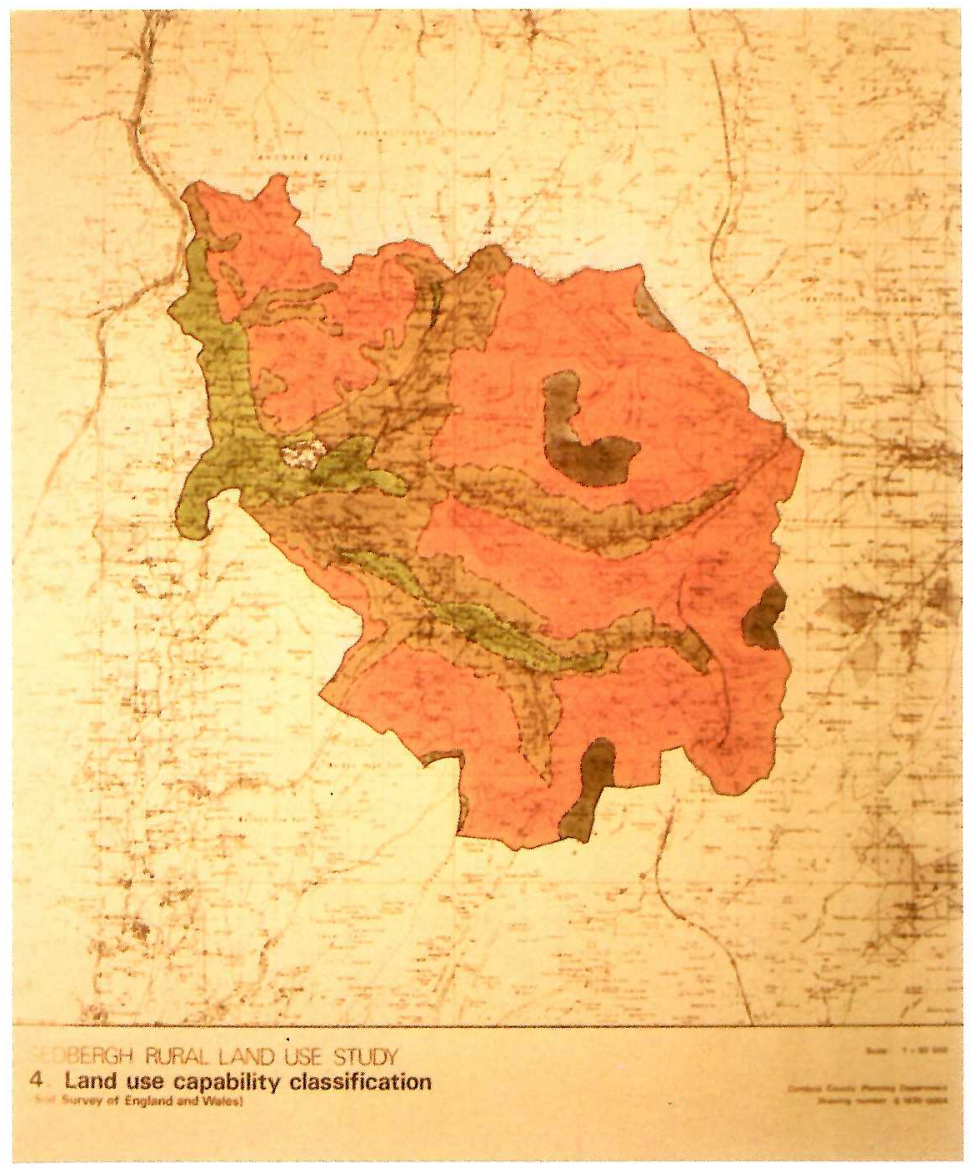

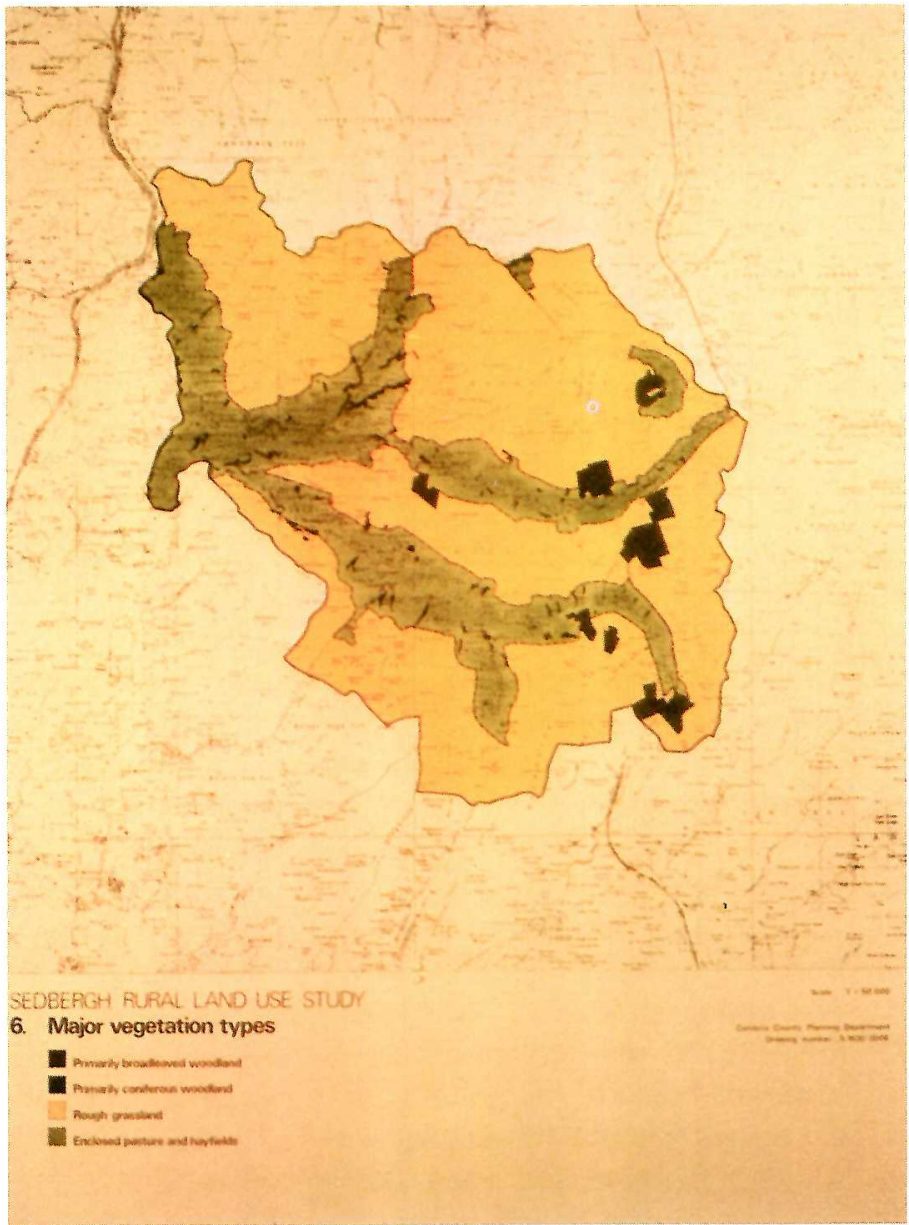

Plate 7 Major vegetation types map, Sedbergh area (based on information from the Nature Conservancy Council)

Plates 5, 6 and 7 are colour wash display maps, 1:50000 prepared during Sedbergh rural land use study, and exhibited at the Merlewood Research Station Open Day 1979 (All three photographs by Ken Leech) 
the time, was calculated to be 60 points after 3 grid squares, ie 24 points, had been surveyed (Adamson. personal communication).

A land classification and resource assessment of the Sedbergh area (Smith \& Budd 1982) was supplemented by a complete survey of the soils (Plate 5) and agricultural land capability (Plate 6 ) by the Soil Survey of England and Wales (Bendelow \& Carroll 1978). This survey provided data from a random selection of 10 grid squares from each land class. The sample estimates were often very similar to the totals obtained from the complete regional survey (Table 6). The mean frequency of each land capability class, calculated from a survey of the whole area of a number of sample squares, stabilises after about 10 squares. Estimates for the relative frequency of the different soil types stabilise at a similar number (Figure 6).

Table 6 RELATIVE FREQUENCY OF AGRICULTURAL CAPABILITY CLASSES IN EACH LAND CLASS

\begin{tabular}{|c|c|c|c|c|c|c|c|c|}
\hline \multirow[t]{3}{*}{$\begin{array}{l}\text { Land } \\
\text { class }\end{array}$} & \multicolumn{2}{|c|}{$\begin{array}{l}\text { Capability } \\
\text { class } 4\end{array}$} & \multicolumn{2}{|c|}{$\begin{array}{l}\text { Capability } \\
\text { class } 5\end{array}$} & \multicolumn{2}{|c|}{$\begin{array}{c}\text { Capability } \\
\text { class } 6\end{array}$} & \multicolumn{2}{|c|}{$\begin{array}{c}\text { Capability } \\
\text { class } 7\end{array}$} \\
\hline & \multicolumn{2}{|c|}{ Sample } & \multicolumn{2}{|c|}{ Sample } & \multicolumn{2}{|c|}{ Sample } & \multicolumn{2}{|c|}{ Sample } \\
\hline & & mplete & & Complete & & omplete & & omplet \\
\hline 5 & - & - & - & - & 56.2 & 68.3 & 43.8 & 31.7 \\
\hline 6 & - & - & - & - & 55.2 & 54.2 & 44.8 & 45.8 \\
\hline 8 & - & - & 11.6 & 11.6 & 85.6 & 87.8 & 2.8 & 0.6 \\
\hline 7 & - & - & - & 0.7 & 92.4 & 91.8 & 7.6 & 7.5 \\
\hline 2 & - & - & 24.0 & 9.6 & 73.6 & 89.9 & 2.4 & 0.5 \\
\hline 1 & - & - & 19.8 & 15.8 & 80.2 & 84.2 & - & - \\
\hline 3 & - & - & - & 4.8 & 100.0 & 95.2 & - & - \\
\hline 4 & - & - & 9.6 & 14.9 & 90.4 & 85.1 & - & - \\
\hline 9 & 6.4 & 1.9 & 13.6 & 13.6 & 80.0 & 84.7 & - & - \\
\hline 12 & - & - & 22.7 & 23.3 & 77.3 & 76.7 & - & - \\
\hline 11 & - & 0.7 & 32.8 & 41.7 & 67.2 & 57.6 & - & - \\
\hline 10 & 0.4 & 0.8 & 27.0 & 34.1 & 72.6 & 65.1 & - & - \\
\hline 14 & 48.8 & 47.0 & 51.2 & 50.9 & - & 2.1 & - & - \\
\hline 16 & 1.8 & 12.7 & 79.2 & 70.8 & 19.0 & 16.5 & - & - \\
\hline 15 & 43.2 & 28.1 & 52.6 & 67.5 & 4.2 & 4.4 & - & - \\
\hline 13 & 84.6 & 75.6 & 15.4 & 24.4 & - & - & - & - \\
\hline
\end{tabular}

1. Sample size $=10$

2. A complete survey of all the grid squares in the region

If an estimate of the more infrequent characteristics in a land class area is required, then the sample size has to be increased accordingly. The 10 samples taken for Figure 6 missed 3 soil types which occurred with a mean frequency of less than $1 \%$. If a feature is rare throughout the survey area, it may not be picked out at all in the sample grid squares. If the feature is of particular interest, then a separate survey will have to be made for it. However, some features may be rare but associated with a particular land class. This is the case with some lichens in Cumbria (Bunce personal communication). Once such an association has been recognised, then a complete survey of the appropriate land classes will enable the distribution of the rare feature to be fully assessed.

This method of checking the adequacy of the sample size can be supplemented by assessing the correlation between the land classification and the data collected. A comparison of the frequency of a feature predicted from a regional survey against data collected from a

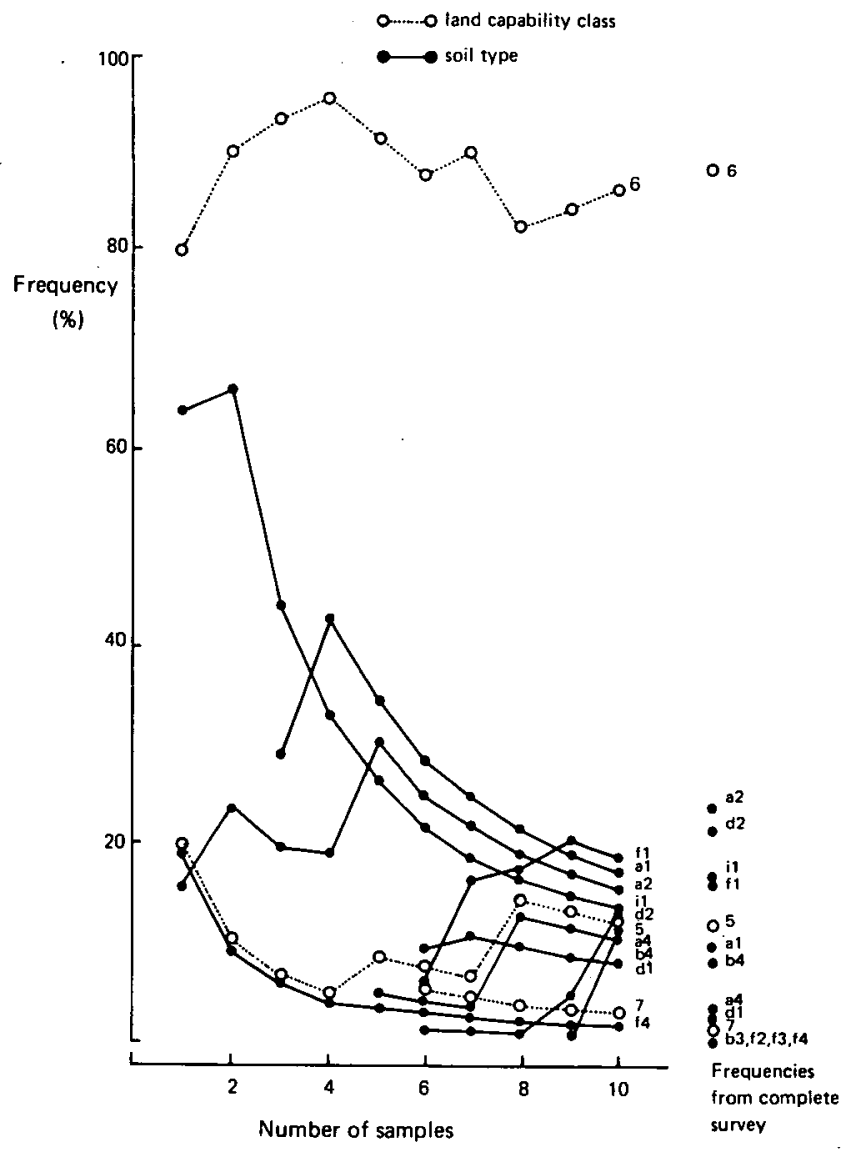

Figure 6 The changing frequency of soil types and land capability classes with increasing sample size from Sedbergh land class 8

a1 Humic rankers over slate and shale with raw peat soils

a2 Humic rankers over slate and shale

a4 Humic rankers over limestone

b3 Typical brown earths and stagnogleyic brown earths, in drift with slate and sandstone

b4 As b3 on steeper slopes at higher elevations with some podzolic soils and rankers

d1 Ironpan stagnopodzols in drift with sandstone and shale, with humic rankers over sandstone and grit

d2 Irompan stagnopodzols and humic brown podzolic soils in drift with slate and sandstone

1 Cambric stagnohumic gley soils in drift with sandstone and shale: shallow peat is a minor component

$\mathrm{f} 2$ As $\mathrm{f} 1$ but less humose

f3 Cambic stagnohumic gleys over shale

f4 As $\mathrm{f} 3$ but including drift with sandstone

i1 Raw peat soils

5 Land capability class 5

6 Land capability class 6

7 Land capability class 7

sub-region can also serve as a check on the adequacy of the original regional survey.

The position of the sample grid squares on the first ordination axis within the indicator species analysis can be used to order the land classes such that those placed together are similar to one another. The land classification for Cumbria gave the following order for the land classes: $7,8,5,6,1,2,4,3,11,12,10,9,13$, $15,14,16$. This shows the trend, from left to right, from the coast $(7,8)$; the lowland of the Solway Plain and other estuaries $(5,6)$; the coastal fringe and Eden valley $(1,2)$; through the higher altitude land where the lowlands begin to merge into the Cumbrian uplands (4, $3)$; the transitional fringe proper $(11,12,10,9)$; to the fringing Pennine and Lake District uplands $(13,15)$ and the central Pennines and Lake District $(14,16)$. 
The overall trend within these land classes is dominated by altitude, but with a separation within each group of lowland, marginal and upland land classes based on geology, land use and land form.

The samples chosen for field survey can be similarly ordered and the mean value for each land class used to rank order them according to the field characteristics. A survey of 3 sample squares from each of the Cumbrian land classes identified 32 vegetation types. The rank order of the land classes based on this vegetation analysis was as follows: $14,9,16,13,15,11,10,12$. $4,1,3,6,2,5$. Land classes 7 and 8 were omitted from this ordering as they did not contain enough vegetation samples; as coastal land classes, many of the sample points fell on intertidal sand or mud. A comparison of the rank orders using the mean values for each land class on each of the first ordination axes shows a strong diagonal element with a very significant correlation coefficient of $0.9(P<0.01)$ (Figure 7). The absence of clusters within this graph indicates that this high value is not an artefact. Therefore, despite the small sample, it appears that it is adequate to identify the vegetation trends and give an estimate of the main features of Cumbria's vegetation.

Such a field survey can be used to predict the vegetation characteristics of a sub-region from its land class composition. It should not be used to predict the composition of a single grid square, without bearing in mind the sampling problems detailed above, ie the aim should not be to predict specific events from a general survey. The sub-region should contain enough grid squares to enable reasonable predictions to be made. A comparison between the predicted and observed vegetation in the Sedbergh area of the Yorkshire Dales National Park (Plate 7) is given in Table 7 (from Bunce $\&$ Smith 1978). If the frequencies are ranked, then 4 out of the 8 lowest values are the same and the largest difference in percentage is $4.3 \%$, with 22 out of the 32 having a difference of less than 1\%. It is, however, difficult to estimate how much of the differences between observed and expected frequencies are due to error, and how much to the inherent characteristics of a region. Table 7 shows that the differences between observed and expected values follow patterns, with groups of adjacent vegetation types having similar differences between observed and expected frequencies. Thus, in comparison with the norm for the Cumbrian land classes, there is less old permanent pasture, permanent pasture and recently improved pasture than expected, but more acid seepages, high level slopes and moorland. Such results support local knowledge, in that the region has very narrow valleys and would, therefore, be expected to be deficient in lowland vegetation types.

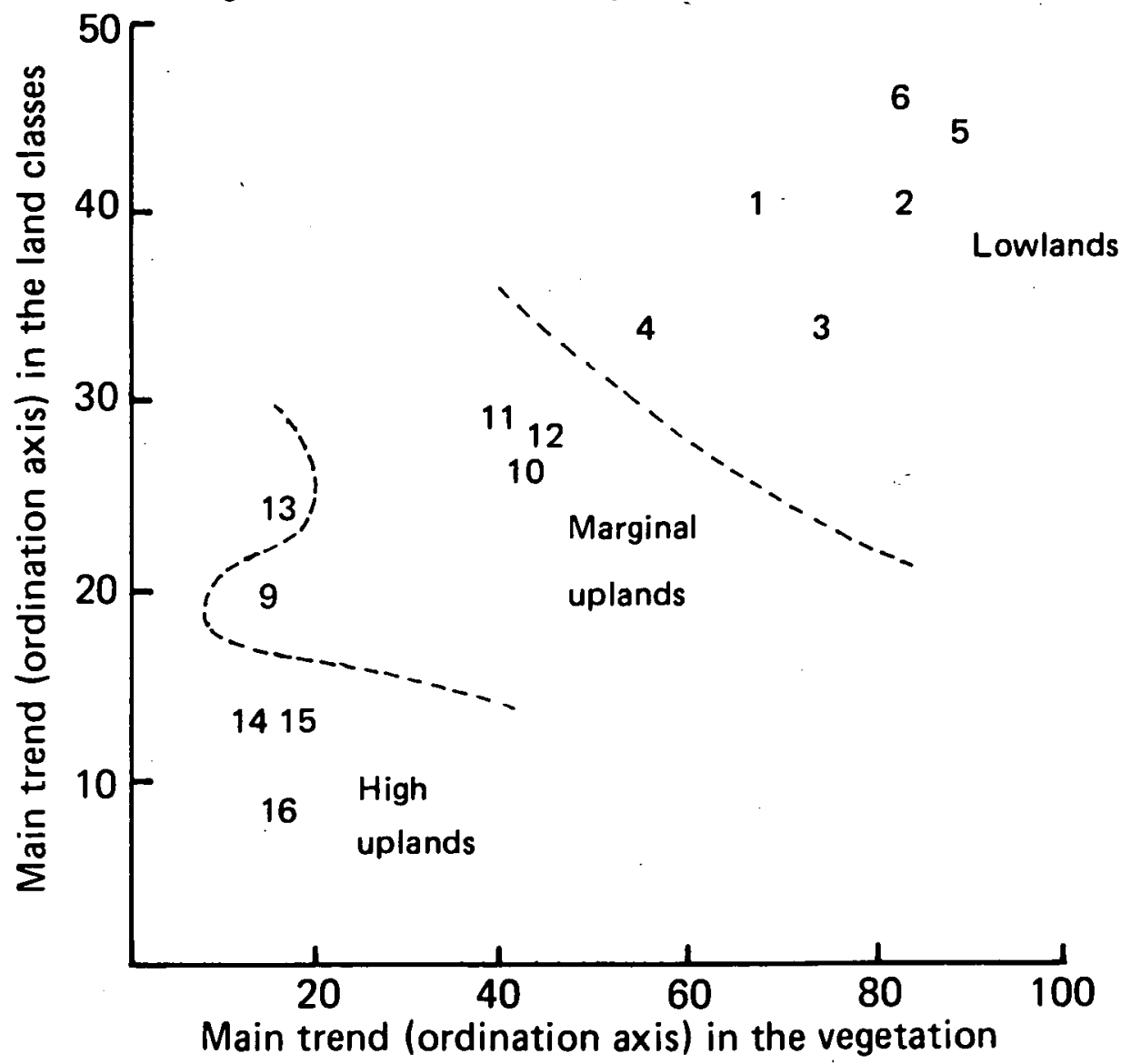

Figure 7 A comparison of the main trends in the Cumbrian land classes and their vegetation

As with Figures 1,2 and 9 these trends were identified by reciprocal averaging ordination (Hill 1973). The further apart 2 points appear along each axis of the graph then the more dissimilar they are in terms of the data that were used to characterise them. For example, land classes 6 and 14 are very dissimilar the graph then the more dissimilar they are in terms of the data that were used to characterise them. For example, land classes 6 and 14 are very dissimilar
in their vegetation composition as they occupy extreme positions on the vegetation axis. In fact, land class 6 has a preponderance of ley grassland, whereas land class 14 is dominated by rough grassland. These vegetational differences are reflected in the land class differences, the 2 land classes occupying opposite ends of the land class axis. Land class 6 occurs on the Solway Plain and is characterised by its very low altitude, urban areas, roads and railways. Land class 14 occurs on the high tops of the Pennines and is characterised by altitudes greater than $1750 \mathrm{ft}$ and a limestone geology 
Table 7 OBSERVED AND EXPECTED FREQUENCIES OF VEGETATION TYPES IN THE PARISHES OF SEDBERGH, DENT AND GARSDALE

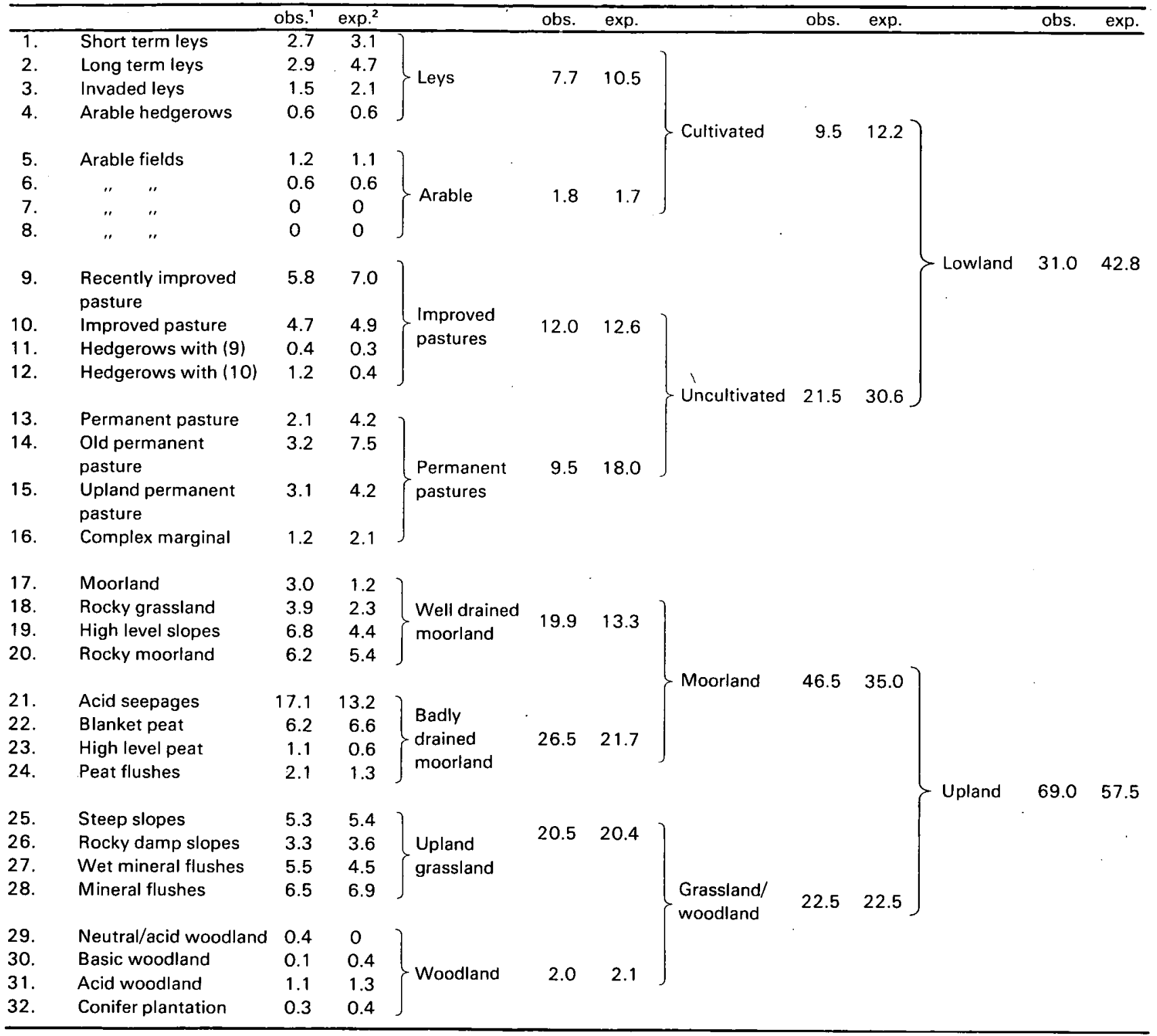

1. Observed frequencies taken from a local survey of the Sedbergh area

2. Expected frequencies calculated from a regional survey of Cumbria

These checks on the adequacy of the sampling regime give an indication of the use to which data from the first and second stages can be put. These are the only stages that are required for some planning purposes. The main need is often for an estimate of the total amount of some ecological resource in a county, and perhaps a comparison of 2 regions of the county. The 1 $\mathrm{km}^{2}$ Cumbria survey provides 2 examples of surveys for both these purposes. The first is a survey of the tree cover in the county, and the second is a comparison of the vegetation of the Lake District National Park with that of the rest of Cumbria.

\section{A TREE COVER SURVEY OF CUMBRIA}

The species composition of the tree cover of Cumbria was surveyed for information on the distribution of elm. The virulent strain of the fungus Ceratocystis ulmi, the causative organism of the current outbreak of Dutch elm disease, had been identified from a tree in Ambleside in 1975. The disease had spread over most of southern England since it first appeared in 1969, and information was wanted on its probable impact in Cumbria. Decisions on how to try and control the disease required information on the species of elm in Cumbria and on their distribution, density and relative frequency compared with other tree species.

The general vegetation survey of the county identified a number of woodland types, but the method of data collection (16 random points in each sample square) only allowed the commonest vegetation types to be adequately sampled. Furthermore, the tree cover information required was more detailed than had previously been collected. Therefore, 4 sample squares were surveyed at random from each Cumbrian land class. Each square was completely surveyed for its tree cover. The isolated and hedgerow trees above $5 \mathrm{~m}$ in height were all counted and the woodland areas were marked on maps. The relative frequency of the species in the tree canopy of each woodland was estimated visually and converted to absolute numbers using a standard density of 494 trees/hectare. This figure had been 
obtained as a mean value from detailed surveys of 10 randomly chosen broadleaved and broadleaved/ coniferous woods (Smith 1977).

Fifty-nine tree species were recorded, of which 31 were native. They occurred in a wide range of situations, from large coniferous plantations to oakwoods and ornamental parks. Land classes 4,10 and 11 were the most heavily wooded, with land classes 7, 14 and 16 quite treeless. Altogether, 25\% of the sample squares were treeless. The commonest species are listed in Table 8 , and the distribution of some within

Table 8 THE MAIN TREE SPECIES IN CUMBRIA*

\begin{tabular}{lrr}
\hline Species & Woodland trees & $\begin{array}{r}\text { Isolated/ } \\
\text { hedgerow trees }\end{array}$ \\
\hline Acer pseudoplatanus & 590,300 & 98,700 \\
Alnus glutinosa & 261,200 & 195,700 \\
Betula pendula & $1,591,100$ & 103,300 \\
Betula pubescens & $2,099,500$ & 56,000 \\
Crataegus monogyna & 60,300 & 78,200 \\
Fagus sylvatica & 340,500 & 57,000 \\
Fraxinus excelsior & 642,900 & 266,000 \\
llex aquifolium & 94,900 & 12,900 \\
Larix decidua & 933,300 & 82,600 \\
Larix kaempferi & $1,724,200$ & 10,100 \\
Picea abies & $1,824,000$ & 20,100 \\
Picea sitchensis & $11,344,300$ & 6,200 \\
Pinus sylvestris & $1,434,100$ & 25,200 \\
Prunus avium & 47,800 & 18,000 \\
Quercus petraea & 821,100 & 43,900 \\
Quercus robur & $2,908,900$ & 261,400 \\
Salix cinerea & 98,900 & 30,100 \\
Sorbus aucuparia & 257,300 & 23,400 \\
Taxus baccata & 58,500 & 4,500 \\
Ulmus glabra & 801,900 & 42,400 \\
Total of non-plantation trees & $10,675,100$ & $1,291,500$ \\
\hline
\end{tabular}

"Data from Smith (1977)

the land classes is shown in Figure 8. Plantation species such as Picea sitchensis are the most abundant. These estimates of their relative frequencies are, however, not likely to be accurate. Forestry is a relatively new land use, covering large areas of land and quickly superimposed on top of the older, much more slowly evolved land use pattern. It tends not to be closely correlated with the land classes when planted in very large, administratively convenient blocks (Bunce \& Smith 1978). Quercus robur is the most frequent non-plantation woodland species, followed by the 2 Betula spp. As a hedgerow tree, it is almost as frequent as Fraxinus exce/sior (Table 9). From the point of view of the original purpose of the survey, the only elm species found was Ulmus glabra which occurs relatively infrequently both in woods and as an isolated tree. It is scattered through the land classes, reaching its greatest number and highest frequency in land class 1 (Table 10).

These species were found in semi-natural woods or in more obviously planted woods of non-native species. Shelterbelts of coniferous and broadleaved trees were found and the more unusual species were located in parks, gardens and roadsides. One hypothesis suggested by this analysis of Cumbria's tree cover is that the change from natural woodland cover to the present situation has not been haphazard. The species composition of the original woodland would have been closely related to the natural environment. Removal of this woodland cover by man and his grazing animals appears to have been selective, and species chosen for replanting have themselves been related to the environment. The overall variation in tree cover is, therefore, presently related to the climatic, topographic, geological and land use factors. This is suggested by the significant correlation coefficient $(r=$ $0.71, P<0.01)$ between the first ordination axis of the land classification and that of an ordination based on the abundance of each tree species in the sample squares (Figure 9).

Table 9 RELATIVE FREQUENCY OF NON-PLANTATION TREE SPECIES IN CUMBRIA*

\begin{tabular}{lcc}
\hline Species & Woodland trees & $\begin{array}{c}\text { Isolated/ } \\
\text { hedgerow trees }\end{array}$ \\
\hline Acer pseudoplatanus & $\%$ & $\%$ \\
Alnus glutinosa & 5.5 & 7.6 \\
Betula pendula & 2.4 & 15.2 \\
Betula pubescens & 14.9 & 8.0 \\
Crataegus monogyna & 19.7 & 4.3 \\
Fagus sylvatica & 0.6 & 6.1 \\
Fraxinus excelsior & 3.2 & 4.4 \\
llex aquifolium & 6.0. & 20.6 \\
Prunus avium & 0.9 & 1.0 \\
Quercus petraea & 0.4 & 1.4 \\
Quercus robur & 7.7 & 3.4 \\
Salix cinerea & 27.2 & 20.2 \\
Sorbus aucuparia & 0.9 & 2.3 \\
Taxus baccata & 2.4 & 1.8 \\
Ulmus glabra & 0.5 & 0.3 \\
\hline
\end{tabular}

*Data from Smith (1977)

Table 10 PREDICTED NUMBER OF ELM TREES IN CUMBRIA

\begin{tabular}{|c|c|c|c|c|c|}
\hline \multirow[b]{2}{*}{$\begin{array}{l}\text { Land } \\
\text { class } \\
\end{array}$} & \multicolumn{2}{|c|}{ Isolated/hedgerow trees } & \multicolumn{2}{|c|}{ Woodland trees } & \multirow[t]{2}{*}{ All elm trees } \\
\hline & $\begin{array}{c}\text { Mean } \\
\text { number } \\
\text { per grid sq. }\end{array}$ & $\begin{array}{c}\text { County* } \\
\text { total }\end{array}$ & $\begin{array}{c}\text { Mean } \\
\text { number } \\
\text { per grid sa. }\end{array}$ & $\begin{array}{c}\text { County } \\
\text { total }\end{array}$ & \\
\hline 7 & - & 二 & - & - & - \\
\hline 8 & - & 一 & - & - & - \\
\hline 5 & 8 & 6,200 & 16 & 12,400 & 18,600 \\
\hline 6 & 6 & 1,700 & 37 & 10,500 & 12.200 \\
\hline 1 & 32 & 28,600 & 774 & 692,700 & 721,300 \\
\hline 2 & 3 & 2,300 & 21 & 16,400 & 18.700 \\
\hline 4 & $<1$ & 600 & $<1$ & 200 & 800 \\
\hline 3 & 3 & 1,600 & - & - & 1,600 \\
\hline 11 & $<1$ & 100 & - & - & 100 \\
\hline 12 & - & - & - & - & - \\
\hline 10 & 4 & 1,400 & 193 & 69,300 & 70,700 \\
\hline 9 & - & 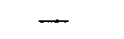 & $\cdots$ & - & - \\
\hline 13 & - & - & - & -- & - \\
\hline 15 & $<1$ & - & - & - & - \\
\hline 14 & - & - & - & - & 一 \\
\hline 16 & - & - & - & - & 一 \\
\hline Total & & 42,500 & & 801,500 & 844,000 \\
\hline
\end{tabular}

- Totals given to the nearest 100 

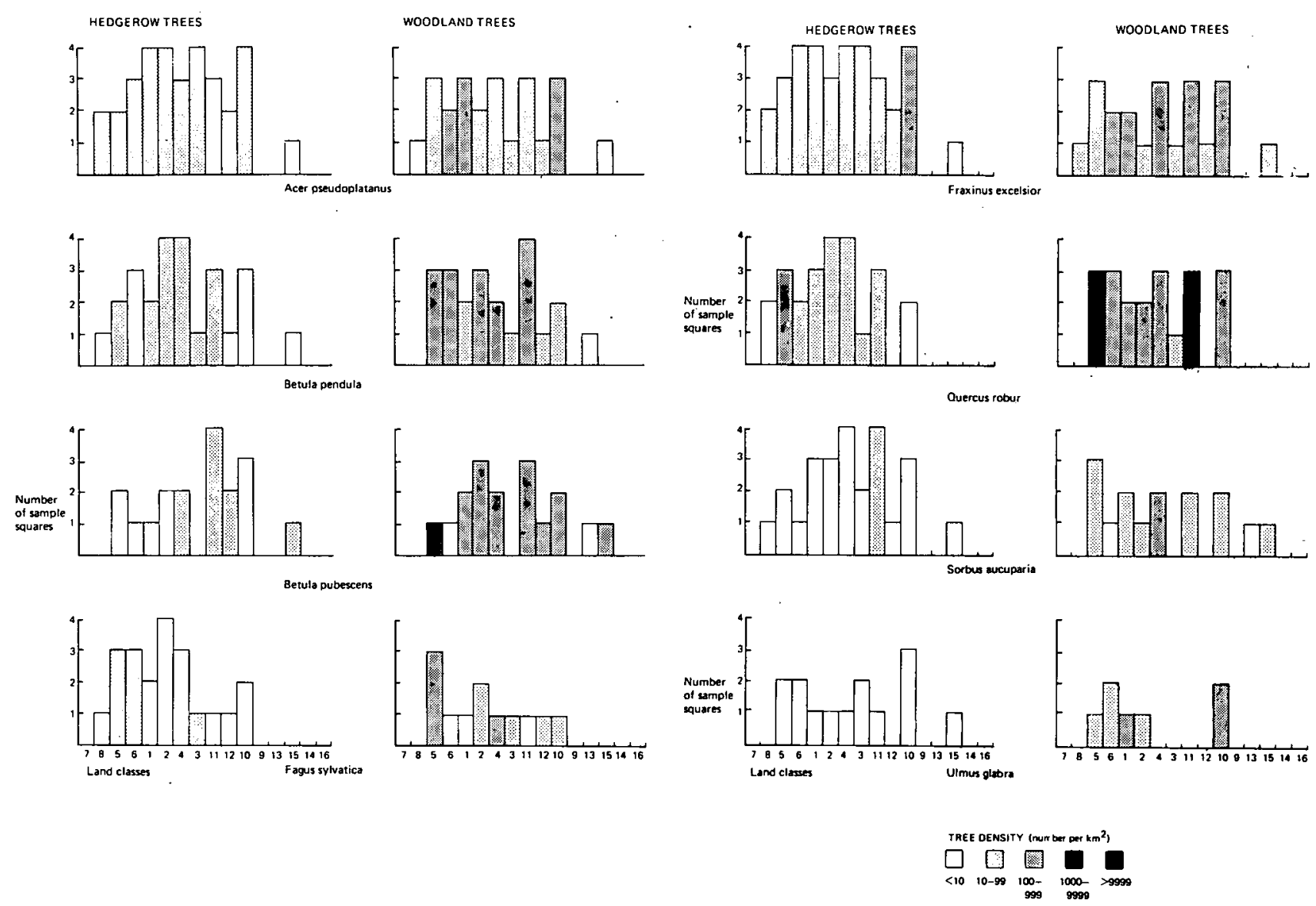

Figure 8 The distribution of some hedgerow and woodland tree species amongst the Cumbrian land classes. From Smith (1977)

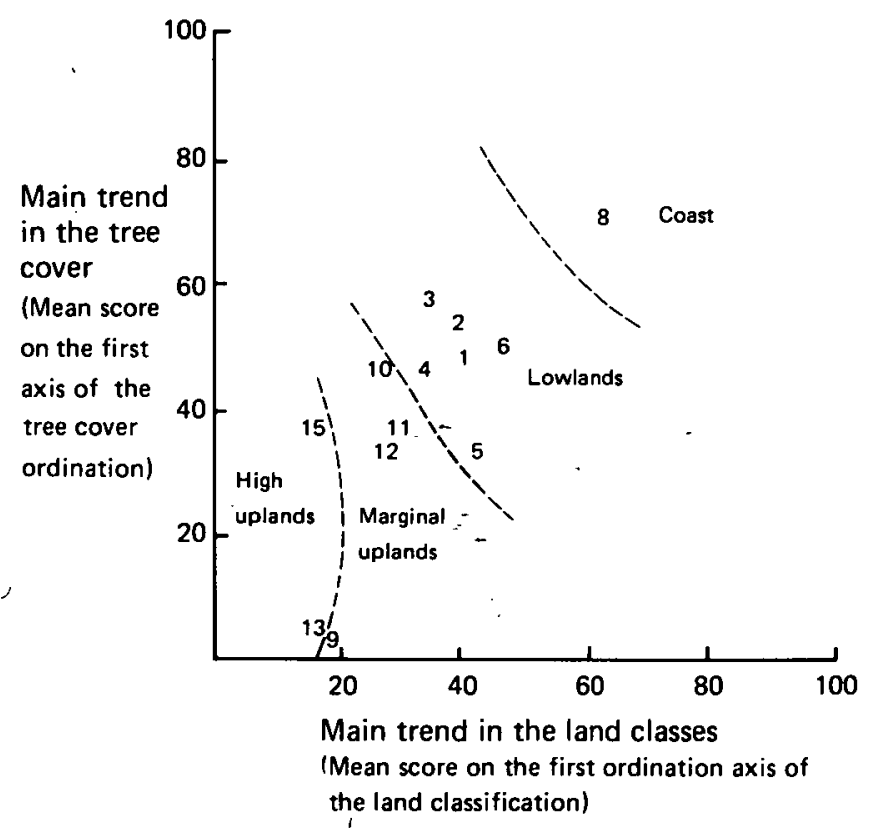

Figure 9 A comparison of the main trends in the Cumbrian land classes and their tree cover

Refer to Figure 7 for the interpretation of this graph

A check on the accuracy of the tree cover estimates is available for the Lake District National Park. Taylor (1978) states that there are 2449 broadleaved woods covering $11,600 \mathrm{ha}$, and that there are 713 coniferous woods of less than 40 ha covering 3893 ha. The predicted number of woods from the sample survey was 3639 , covering an area of 16,323 ha. These predicted figures are respectively $16.8 \%$ and $5.4 \%$ lower than those quoted by Taylor. Coniferous woods greater than 40 ha in extent have been excluded from this comparison because of their ill-defined relationship with the land classes, particularly in the National Park where restrictive planting policies have operated since 1936.

\section{VEGETATION DIFFERENCES BETWEEN AREAS}

Assessment of the adequacy of the size of the sample by comparing the predicted vegetation character against that observed for the Sedbergh area showed how a regional survey could be used to predict the expected county "norm" for a sub-region. A comparison of the vegetation of the Lake District National Park with the remainder of Cumbria illustrates how specific differences can be identified (Bunce \& Smith 1978). The upland character of the National Park's vegetation is a major feature, as is the dominance of lowland vegetation outside the Park (T.able 11). In the lowland vegetation types, the main difference is in the predominance of cultivated arable and ley grasslands outside the Park: $26 \%$ outside the Park, $11 \%$ in the Park. Upland moorland is twice as frequent in the Park, but occupies approximately the same area of land in both regions. The Lake District has a much larger proportion of well drained moorland than the rest of Cumbria: $23 \%$ in the Park as against $6 \%$ outside. 
Table 11 COMPARISON OF THE VEGETATION TYPES IN THE LAKE DISTRICT NATIONAL PARK WITH THE REST OF CUMBRIA*

\begin{tabular}{|c|c|c|c|c|c|}
\hline & \multirow[t]{2}{*}{ Vegetation type } & \multicolumn{2}{|c|}{$\begin{array}{l}\text { Frequency } \\
\text { (\%) }\end{array}$} & \multicolumn{2}{|c|}{$\begin{array}{l}\text { Area } \\
\left(\mathrm{km}^{2}\right)\end{array}$} \\
\hline & & $\begin{array}{l}\text { Out- } \\
\text { side } \\
\text { Park }\end{array}$ & LDNP & $\begin{array}{l}\text { Out- } \\
\text { side } \\
\text { Park }\end{array}$ & LDNP \\
\hline 1 & Short term leys & 7.7 & 3.5 & 397 & 70 \\
\hline 2 & Long term leys & 6.7 & 2.5 & 346 & 50 \\
\hline 3 & Invaded leys & 6.2 & 3.8 & 320 & 76 \\
\hline 4 & Arable hedgerows & 3.2 & 1.7 & 165 & 34 \\
\hline 5 & Arable fields & 2.3 & 1.1 & 118 & 22 \\
\hline 6 & Arable fields & 1.7 & 0.8 & 87 & 16 \\
\hline 7 & Arable fields & 3.1 & 1.4 & 160 & 28 \\
\hline 8 & Arable fields & 2.0 & 0.9 & 103 & 18 \\
\hline 9 & Recently improved pasture & 7.6 & 5.4 & 392 & 108 \\
\hline 10 & Improved pasture & 7.6 & 5.6 & 392 & 112 \\
\hline 11 & Hedgerow associated with $\mathbf{9}$ & 2.4 & 1.2 & 123 & 24 \\
\hline 12 & Hedgerow associated with 10 & 2.6 & 2.3 & 134 & 46 \\
\hline 13 & Permanent pasture & 3.9 & 2.1 & 201 & 42 \\
\hline 14 & Old permanent pasture & 4.3 & 3.2 & 222 & 64 \\
\hline 15 & Upland permanent pasture & 2.3 & 2.2 & 118 & 44 \\
\hline 16 & Complex marginal habitats & 2.2 & 2.4 & 113 & 48 \\
\hline 17 & Moorland & 2.1 & 6.6 & 108 & 133 \\
\hline 18 & Rocky grassland & 1.1 & 4.8 & 56 & 96 \\
\hline 19 & High level slopes & 2.4 & 7.5 & 123 & 151 \\
\hline 20 & Rocky moorland & 5.0 & 5.2 & 258 & 104 \\
\hline 21 & Acid seepages & 5.6 & 8.1 & 289 & 163 \\
\hline 22 & Blanket peat & 4.4 & 9.6 & 227 & 193 \\
\hline 23 & High level peat & 0.5 & 3.9 & 25 & 78 \\
\hline 24 & Peat flushes & 1.2 & 1.6 & 62 & 32 \\
\hline 25 & Steep mountain slopes & 2.2 & 3.5 & 113 & 7.0 \\
\hline 26 & Rocky, damp slopes & 2.4 & 3.1 & 123 & 62 \\
\hline 27 & Wet, mineral flushes & 1.9 & 1.9 & 98 & 38 \\
\hline 28 & Mineral flushes & 2.2 & 1.7 & 113 & 34 \\
\hline 29 & Neutral/acid woodland & 0.9 & 0.7 & 46 & 14 \\
\hline 30 & Basic woodland & 1.0 & 0.7 & 51 & 14 \\
\hline 31 & Acid woodland & 1.1 & 1.5 & 56 & 30 \\
\hline 32 & Conifer plantation & 0.4 & 0.3 & 20 & 6 \\
\hline $1-4$ & Leys & 23.7 & 11.4 & 1223 & 231 \\
\hline $5-8$ & Arable & 9.0 & 4.1 & 464 & 84 \\
\hline $9-12$ & Improved pasture & 20.1 & 14.4 & 1038 & 292 \\
\hline $13-16$ & Permanent pasture & 12.6 & 9.8 & 650 & 199 \\
\hline $17-20$ & Well drained moor & 10.5 & 24.0 & 542 & 485 \\
\hline $21-24$ & Badly drained moor & 11.6 & 23.1 & 599 & 467 \\
\hline $25-28$ & Upland grassland & 8.6 & 10.1 & 444 & 205 \\
\hline $29-32$ & Wooded & 3.3 & 3.1 & 170 & 64 \\
\hline $1-8$ & Cultivated & 32.7 & 15.5 & 1688 & 316 \\
\hline $9-16$ & Uncultivated & 32.7 & 24.2 & 1688 & 492 \\
\hline $17-24$ & Moorland & 22.1 & 47.1 & 1141 & 953 \\
\hline $25-32$ & Grassland/woodland & 11.9 & 13.2 & 614 & 270 \\
\hline $1-16$ & Lowland & 65.4 & 39.7 & 3377 & 808 \\
\hline $17-32$ & Upland & 35.0 & 60.3 & 1807 & 1223 \\
\hline
\end{tabular}

*From Bunce and Smith \{1978\} 


\section{Stage 3: The production of alternative rural land use strategies}

DEVELOPMENT OF A MODEL FOR RURAL LAND USE

Stages 1 and 2 are essentially data collection and data analysis. Numerical techniques have been used to provide a land classification framework for data collection, and to organise and investigate the data collected in the field. The third stage consists of using the data in a model which will enable alternative land use strategies to be developed. Jeffers (1978) describes models as formal expressions of the essential elements of a problem in either physical or mathematical terms. The model utilising the land classification and data collected from each land class is one which optimises an objective function, that might be timber production, subject to one or more constraints. These constraints might be that milk production must not fall below a certain level or areas of wildlife importance should be conserved. The modelling technique is known as linear programming and its application to land use problems using a grid square land classification was first developed by Bishop (1978) in Cumbria. It has been used to investigate the agricultural and forestry potential of land at the regional and local level. The size, type and distribution of farms has not been incorporated into the studies to date. The optimisations for timber, milk, meat production, etc, have been considered for regions in an attempt to understand the physical potential of land for increased productivity without the loss of valued wildlife and landscape resources.

Bishop's original linear programming model utilised the 16 land classes from the Cumbria survey. The potential of each land class for broadleaved forestry, coniferous forestry, livestock rearing (cattle), dairy farming, arable crops, and livestock rearing (sheep) was assessed by extrapolation from regional trends and the relationship with the Ministry of Agriculture's Agricultural Land Classification. The outputs from each land class, under each of these 6 uses, were presented as timber (cubic metres), meat (tonnes), food energy (terajoules), milk (tonnes), recreation and ecological values. The inputs necessary to achieve these outputs were estimated as labour (standard man days) and energy (terajoules). Within the constraints imposed by the strategies, the model maximised the output of one product, such as milk, meat or timber, whilst maintaining the outputs of other products above a minimum level. This was achieved by assigning land uses to land classes in a combination which maximised the output of the desired commodity.

The use of this model is illustrated by Bunce and Smith (1978) for Cumbria. The strategy they describe was one which kept the present land use pattern within the 2 National Parks and the existing and potential Areas of Outstanding Natural Beauty, whilst allowing changes in the rest of the county. The outputs of timber, meat and food energy were optimised in turn, giving a potential increase in each of these commodities of $36 \%, 3 \%$ and $36 \%$, respectively. Further development of the data used by the model was incorporated into a study of the Sedbergh area of the Yorkshire Dales National Park (Smith \& Budd 1982). The basic model as developed by Bishop (1978) was used for this work. The land uses considered were the 5 types of farming (defined by MAFF) as found in the study area, plus a forestry option as presented by the Forestry Commission. Assessment of the productivity of each land class was based upon detailed soil and land capability surveys (Bendelow \& Carroll 1978), instead of an extrapolation of regional trends. The computer modelling of alternative strategies was based solely on the more objectively defined data, the more subjective landscape, nature conservation and recreation values being excluded until a later stage. An independent check on the accuracy of the data was possible from MAFF returns, which allowed more confidence to be placed in the alternative land use patterns suggested by the model. These land use patterns themselves were the product of alternative strategies suggested by members of a steering committee composed of representatives of the National Farmers' Union, the Country Landowners Association. the Forestry Commission, the Ministry of Agriculture, the Yorkshire Dales National Park Authority, the County Council and the Nature Conservancy Council. These alternatives were as realistic as possible and could be evaluated against the subjective values excluded in their generation, as well as against social and economic objectives for the Sedbergh area.

\section{THE COLLECTION OF PRODUCTIVITY DATA FOR THE} SEDBERGH MODEL

The land classification for the Sedbergh area was based on the map attributes present in a grid of $\frac{1}{4} \mathrm{~km}^{2}$ sample squares (Table 4). The resultant land classification, through indicator species analysis of these data, shows a distinct topographical trend into mountain top land classes (5-8), upper middle slope land classes (1-4), lower middle slope land classes (9-12), and valley bottom land classes (13-16) (Pilling et al. 1978) (Figure 10) (see cover photographs for illustrations of these land classes). The largest group contains the lower middle slope land classes which occupy $34.7 \%$ of the area (Table 12).

Bendelow and Carroll (1978) identified 22 soil types in 9 major soil groups according to the classification developed by Avery (1973) (Plate 5). They occur in 3 main topographic areas: valley bottoms, Carboniferous uplands, and Silurian uplands (Table 13). This soil survey was the basis for the land capability classi- 


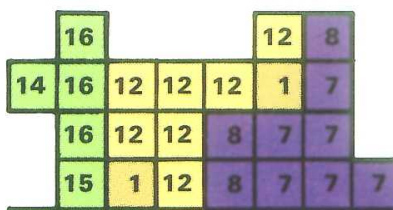

\section{\begin{tabular}{|l|l|l|l|l|l|l|l|l|l|l|l|l|l|l|l|l|l|}
\hline 15 & 15 & 16 & 12 & 8 & 8 & 7 & 8 & 7 & 7 & 7 & 2 & 8 & 2 & 4 & 15 & 16 & 16 \\
\hline
\end{tabular}}

\begin{tabular}{|l|l|l|l|l|l|l|l|l|l|l|l|l|l|l|l|l|l|l|l|l|}
\hline 14 & 14 & 16 & 1 & 12 & 2 & 1 & 8 & 7 & 7 & 7 & 7 & 12 & 16 & 16 & 16 & 16 & 16 & 16 & 16 & 10 \\
\hline
\end{tabular}

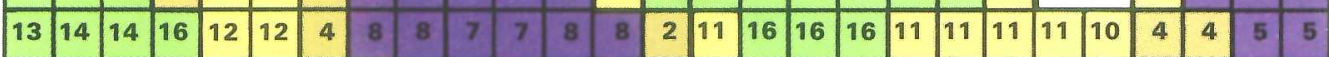

\begin{tabular}{|l|l|l|l|l|l|l|l|l|l|l|l|l|l|l|l|l|l|l|l|l|l|l|l|l|l|l|l|}
\hline 13 & 13 & 15 & 16 & 12 & 16 & 12 & 12 & 8 & 7 & 7 & 8 & 8 & 8 & 15 & 16 & 16 & 11 & 10 & 4 & 4 & 12 & 11 & 10 & 4 & 5 & 5 & 6 \\
\hline
\end{tabular}

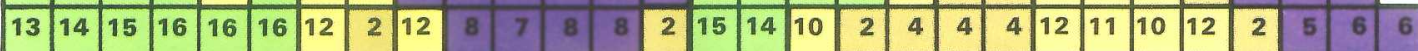

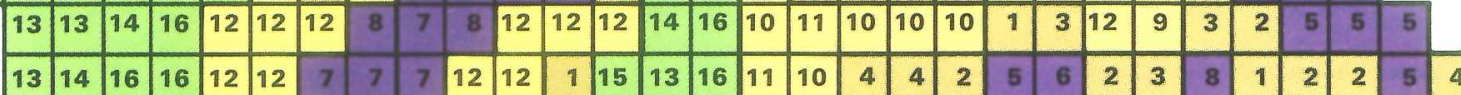

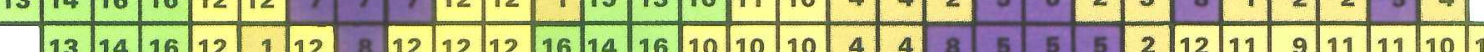

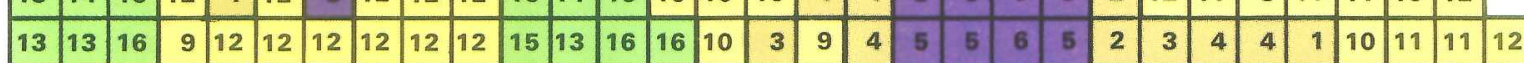

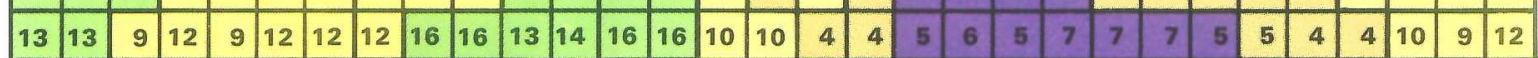

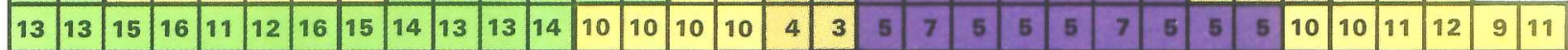

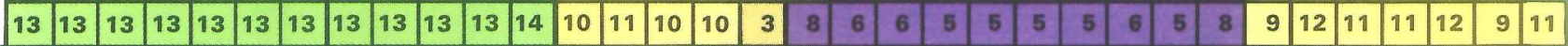

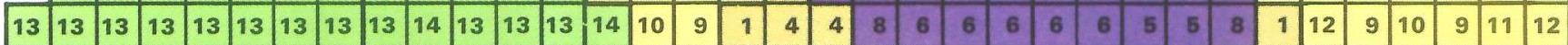

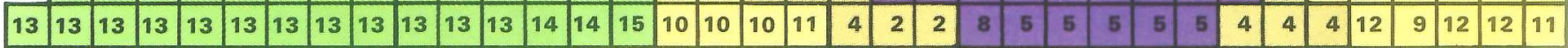

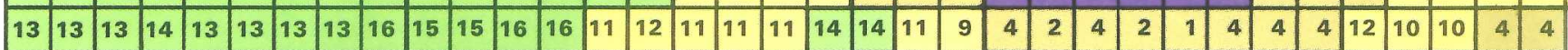

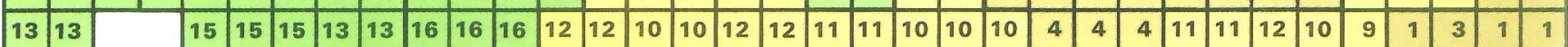

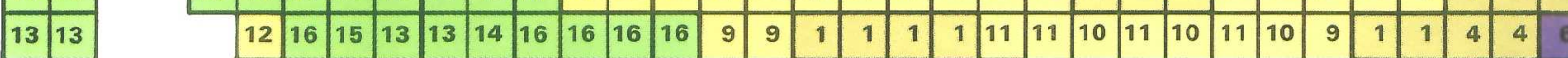

\begin{tabular}{|l|l|l|l|l|l|l|l|l|l|l|l|l|l|l|l|l|l|l|l|l|l|l|l|l|l|}
12 & 4 & 16 & 16 & 13 & 13 & 16 & 16 & 16 & 10 & 9 & 9 & 11 & 11 & 1 & 1 & 11 & 11 & 10 & 9 & 11 & 9 & 9 & 9 & 10 & 12 \\
\hline
\end{tabular}

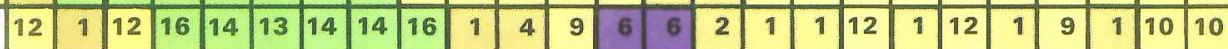

\begin{tabular}{l|l|l|l|l|l|l|l|l|l|l|l|l|l|l|l|l|l|l|l|l|l|l|l|}
16 & 12 & 12 & 12 & 16 & 13 & 14 & 14 & 16 & 1 & 1 & 2 & 8 & 6 & 4 & 11 & 11 & 11 & 1 & 11 & 11 & 3 & 4 & 4
\end{tabular}

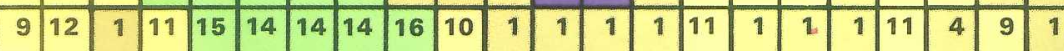

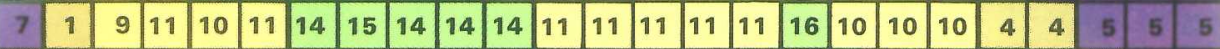

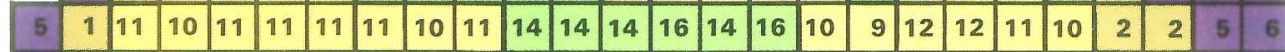

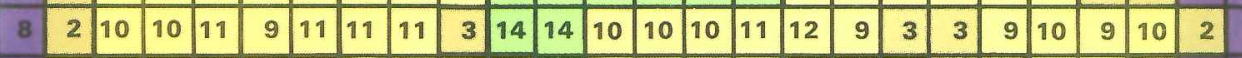

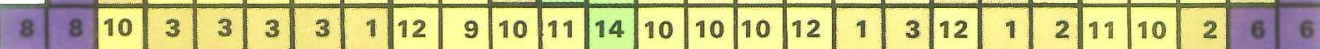

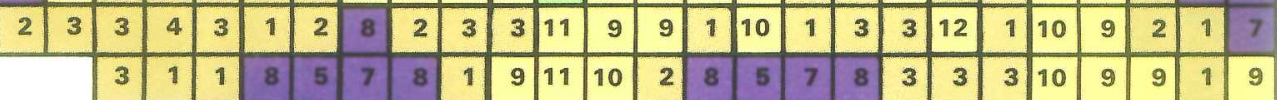

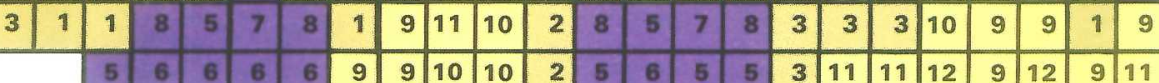

LAND

\begin{tabular}{l|l|l|l|l|l|l|l|l|l|l|l|l|l|l|l|l|l|}
\hline 5 & 6 & 9 & 11 & 11 & 10 & 2 & 5 & 6 & 7 & 5 & 2 & 9 & 12 & 12 & 12 & 11 \\
\hline
\end{tabular}

CLASSES

$$
\begin{gathered}
1-4 \\
5-8 \\
9-12 \\
13-16
\end{gathered}
$$

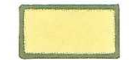

\begin{tabular}{l|l|l|l|l|l|l|l|l}
6 & 2 & 2 & 1 & 11 & 2 \\
\hline
\end{tabular}

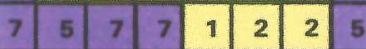

\begin{tabular}{l|l|l|l|l|l|l|l|}
\hline 6 & 2 & 7 & 2 & 10 & 5 & 5 & 5 \\
\hline
\end{tabular}
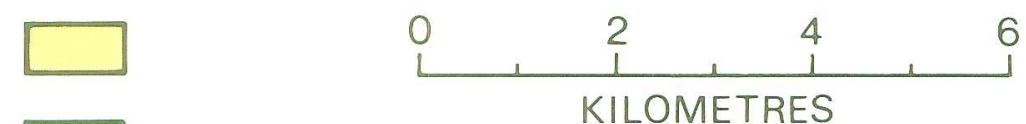

6

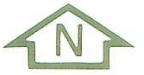


Table 12 SEDBERGH LAND CLASSES*

\begin{tabular}{|c|c|c|c|c|}
\hline & Land class & $\begin{array}{l}\text { Number of } \\
\text { grid squares }\end{array}$ & $\begin{array}{c}\text { Frequency } \\
\%\end{array}$ & $\begin{array}{l}\text { Frequency }(\%) \\
\text { of main land } \\
\text { class groups }\end{array}$ \\
\hline \multirow{4}{*}{$\begin{array}{l}\text { Mountain } \\
\text { tops }\end{array}$} & 5 & 77 & 8.5 & \multirow{4}{*}{21.3} \\
\hline & 6 & 36 & 3.9 & \\
\hline & 8 & 40 & 4.4 & \\
\hline & 7 & 41 & 4.5 & \\
\hline \multirow{4}{*}{$\begin{array}{l}\text { Upper } \\
\text { middle } \\
\text { slopes }\end{array}$} & $2^{-}$ & 44 & 4.9 & \multirow{4}{*}{20.6} \\
\hline & 1 & 62 & 6.9 & \\
\hline & 3 & 29 & 3.2 & \\
\hline & 4 & 51 & 5.6 & \\
\hline \multirow{4}{*}{$\begin{array}{l}\text { Lower } \\
\text { middle } \\
\text { slopes }\end{array}$} & 9 & 51 & 5.6 & \multirow{4}{*}{34.7} \\
\hline & 12 & 96 & 10.6 & \\
\hline & 11 & 87 & 9.6 & \\
\hline & 10 & 81 & 8.9 & \\
\hline \multirow{4}{*}{$\begin{array}{l}\text { Valley } \\
\text { bottoms }\end{array}$} & 14 & 48 & 5.3 & \multirow{4}{*}{23.0} \\
\hline & 16 & 67 & 7.4 & \\
\hline & 15 & 21. & 2.3 & \\
\hline & 13 & 73 & 8.0 & \\
\hline
\end{tabular}

*A land classification using a $\frac{1}{4} \mathrm{~km}^{2}$ grid size and the 128 map characteristics in Table 4. From Pilling et al. (1978)

Table 13 SOIL TYPES IN THE SEDBERGH AREA*

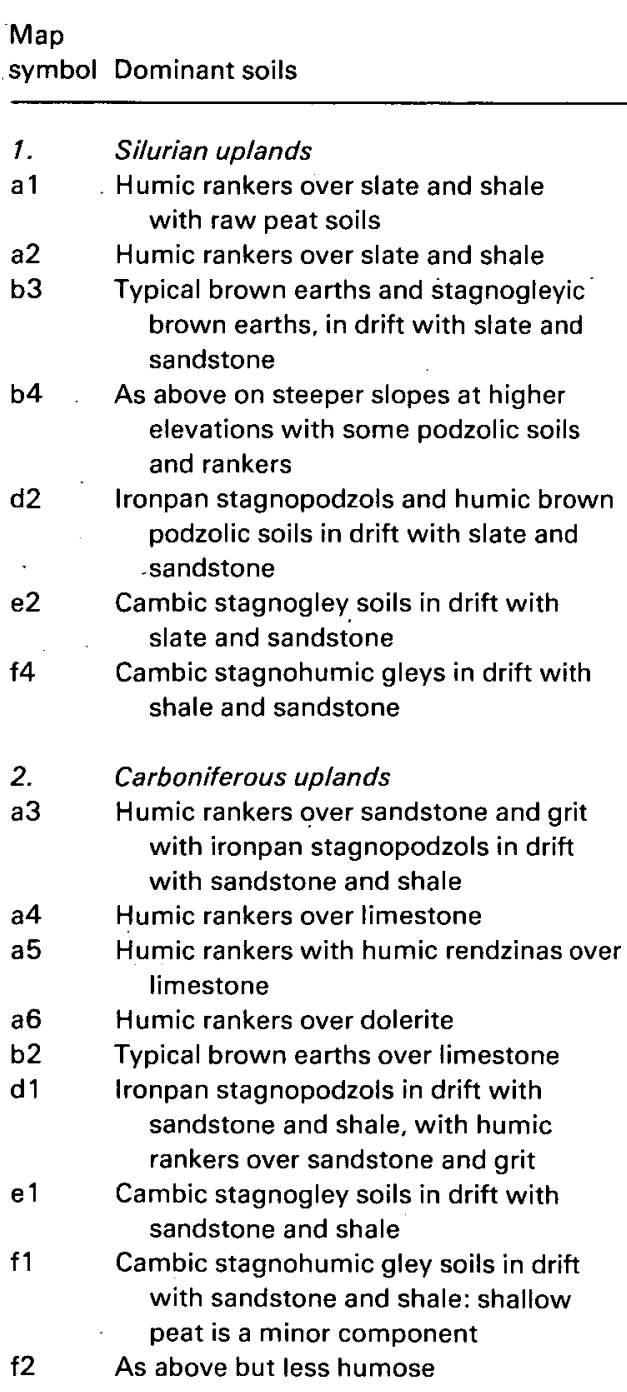

Series name

Un-named

Un-named

Denbigh and

Sannan

Denbigh,

Sannan and

Parc

Hiraethog and Parc

Cegin

Ynys

Revidge and Belmont

Wetton

Wetton and

Marian

Preseli

Lulsgate

Belmont and

Revidge

Brickfield

Wilcocks and Roddlesworth

Wilcocks and f3 Cambic stagnohumic gleys over shale

i1 Raw peat soils

3. Valleys

b1 Typical brown earths in drift (river terrace)

c1 Typical brown alluvial soils and typical alluvial gley soils

g1 Typical cambic gley soils and gleyic brown earths, in drift (river terrace)

h1 Typical alluvial gley soils (lacustrain or riverine)

*From Bendelow and Carroll (1978)

fication using the system described by Bibby and Mackney (1969), which classifies land primarily for agricultural purposes, assumes a moderately high level of management, and is based mainly on the land's physical limitations. There are 7 capability classes, the best 3 of which (classes 1-3) were absent from the area. Capability class 6 is the most frequent of the 4 that are found and occurs in most of the land classes (Table 14) (Plate 6).

Table 14 AGRICULTURAL CAPABILITY CLASSES IN EACH SEDBERGH LAND CLASS* Roddlesworth

\begin{tabular}{|c|c|c|c|c|c|}
\hline & \multirow[t]{2}{*}{$\begin{array}{l}\text { Land } \\
\text { class }\end{array}$} & \multicolumn{4}{|c|}{$\begin{array}{c}\text { Agricultural Capability Classes } 4-7 \\
\text { (\% of the land class area in } \\
\text { each capability class) }\end{array}$} \\
\hline & & 4 & 5 & 6 & 7 \\
\hline \multirow{4}{*}{$\begin{array}{l}\text { Mountain } \\
\text { tops }\end{array}$} & 5 & - & - & 68 & 32 \\
\hline & 6 & - & - & 54 & 46 \\
\hline & 8 & - & 11 & 88 & 1 \\
\hline & 7 & - & 1 & 92 & 7 \\
\hline \multirow{4}{*}{$\begin{array}{l}\text { Upper } \\
\text { middle } \\
\text { slopes }\end{array}$} & 2 & - & 9 & 90 & 1 \\
\hline & 1 & - & 16 & 84 & - \\
\hline & 3 & - & 5 & 95 & - \\
\hline & 4 & - & 15 & 85 & - \\
\hline \multirow{4}{*}{$\begin{array}{l}\text { Lower } \\
\text { middle } \\
\text { slopes }\end{array}$} & 9 & 2 & 13 & 85 & - \\
\hline & 12 & - & 23 & 77 & - \\
\hline & 11 & 1 & 42 & 57 & - \\
\hline & 10 & 1 & 34 & 65 & - \\
\hline & 14 & 47 & 51 & 2 & - \\
\hline Valley & 16 & 13 & 71 & 16 & - \\
\hline \multirow[t]{2}{*}{ bottoms } & 15 & 28 & 68 & 4 & - \\
\hline & 13 & 76 & 24 & - & - \\
\hline
\end{tabular}

*From Smith and Budd (1982)

The assumptions and calculations used to derive labour and production figures for 6 different types of farming in each land class, and for a land use pattern involving considerable afforestation, are given in Annex 1. They are based upon the land capability classification survey by Bendelow and Carroll (1978) with stocking rates based on data from Nix (1978). These labour and production figures proved to be so similar for some land classes that they were used to group them into 7 land class groups, ie 1, 2, 3, 4, 9, $12 / 5,6$, $7,8 / 10,11 / 13 / 14 / 15 / 16$. 
OTHER DATA REQUIRED BY THE MODEL

Apart from the production data relating the chosen land uses to each land class (Annex 1, Tables 27 to 32 ), the other parameters required are the number of grid squares in each land class, the constraint levels, and the output or input to be optimised. These data can be modified to take account of changes in management practice and areas within each land class where certain uses should not be permitted. For instance, it may be that increased agricultural efficiency in the use of grassland means that $10 \%$ more milk can be produced per hectare than at present. To cater for this increased efficiency, the milk coefficients can be raised by $10 \%$. If the use of high grade agricultural land for forestry is not to be permitted, this can be allowed for by reducing the timber output from land classes that have this good land, in proportion to the amount and productivity of that land. The number of grid squares in each land class group in the Sedbergh area is as follows:

Land class group

$1,2,3,4,9,12$

$5,6,7,8$

10,11

13

14

15

16

The model can be based on these or some reduced numbers. It may well be that certain types of land use should not be changed, and the land classes on this land can then be removed from the model. A good example is that of common land, which is not likely to be available for other uses for the foreseable future. The constraint values set the minimum level of each output that the model has to achieve, whilst optimising the desired output. It provides a solution which reflects multiple objectives. The levels can be set at present day outputs, or more or less than at present, dependent upon the strategy being optimised.

\section{ONE POSSIBLE STRATEGY}

An example of the use of the model in generating land use. strategies is taken here from the Sedbergh Rural Land Use Study (Smith \& Budd 1982). The main elements of the strategy are the protection of broadleaved woodland, the restrictions on coniferous afforestation, the protection of good quality agricultural land and the protection of archaeological features. The protection of broadleaved woods is accommodated in the model by assuming that these have no associated agricultural and forestry outputs. This is not exactly true, but they are negligible enough to be ignored here. The output coefficients for each land class are, therefore, reduced by an amount dependent upon the quantity of broadleaved woodland in each land class. The interpretation of the proposed land use pattern then assumes that the agricultural or forest enterprise allocated to a $\frac{1}{4} \mathrm{~km}$ square does not include the woodland in it.
The protection of inbye land and good agricultural land is accommodated by reducing the timber outputs from the forestry land use category by the amount of timber obtained from land in agricultural capability classes 4 and 5. Meat, milk, wool and food energy outputs are allocated to the forestry land use category on the assumption that this land is used for "mainly dairy farming". The labour requirements are modified accordingly. Unplanted land in agricultural capability class 6 is assumed to be used for livestock rearing (sheep). The outputs (meat, milk, food energy and wool) and labour input are calculated according to the proportion of grazing livestock units available from the land.

The protection of recognised sites such as archaeological sites, Sites of Special Scientific Interest (SSSI), and nature reserves is assumed to mean their retention in their present form. The $\frac{1}{4} \mathrm{~km}^{2}$ grid squares which have these sites are excluded from the model. Archaeological features such as the detailed field pattern and head dyke, which the strategy wants conserved for historical and landscape reasons, are catered for in the $15 \%$ reduction in productivity figures, for roads, buildings and boundaries. The protection of significant natural landmarks and features such as Coombe Scar is accommodated by removing the $\frac{1}{4} \mathrm{~km}^{2}$ grid squares they occupy from the model. In this strategy, all the common land, Whernside SSSI, archaeological sites and Coombe Scar have been excluded from consideration. The minimum acceptable outputs from the strategy have been set at present output levels. Meat, milk and wool outputs are taken from MAFF figures; timber is given an arbitrary constraint level of $100 \mathrm{~m}^{3} /$ annum; food energy and labour are calculated from the estimated present pattern of land use provided by MAFF assuming all the common land is used for livestock rearing (sheep). The optimum outputs obtained from the Sedbergh area, with the constraints set by this strategy, depend upon the resource being optimised. The present land use pattern (Table 15) can be adjusted by the model to produce the maximum amount of any desired output; for example, timber (Table 16) or meat (Table 17). The model concentrates the land into certain land classes under specified uses instead of spreading them around.

Table 15 PRESENT LAND USE PATTERN (ESTIMATED)*

\begin{tabular}{lcccccc}
\hline $\begin{array}{l}\text { Land } \\
\text { class } \\
\text { group }\end{array}$ & Forestry & $\begin{array}{c}\text { Specialist } \\
\text { dairy }\end{array}$ & $\begin{array}{c}\text { Mainly } \\
\text { dairy }\end{array}$ & \multicolumn{3}{c}{ Cattle } \\
\hline $5-8$ & - & - & - & - & 10 & 60 \\
$1-4,9,12$ & - & - & 18 & - & 42 & 114 \\
10,11 & - & - & 17 & - & 37 & 59 \\
14 & - & - & 31 & - & 7 & 8 \\
16 & - & 4 & 11 & - & 18 & - \\
15 & - & 1 & 7 & - & 5 & 2 \\
13 & - & 14 & 41 & - & 10 & 4 \\
\hline
\end{tabular}

*The land use pattern in Tables 15, 16 and 17 is given as the number of grid squares in each land class estimated to be in. or allocated to, each type of farming and forestry 
Table 16 A RURAL LAND USE MODEL FOR THE SEDBERGH AREA: STRATEGY: TIMBER OPTIMISATION (DETAILED LAND USE PATTERN PROPOSED BY MODEL)

\begin{tabular}{lcccccc}
\hline $\begin{array}{l}\text { Land } \\
\text { class } \\
\text { group }\end{array}$ & Forestry & $\begin{array}{c}\text { Specialist } \\
\text { dairy }\end{array}$ & $\begin{array}{c}\text { Mainly } \\
\text { dairy }\end{array}$ & $\begin{array}{c}\text { Livestock rearing } \\
\text { Cattle Cattle \& Sheep Sheep }\end{array}$ \\
\hline $5-8$ & 72 & - & - & - & - & - \\
$1-4,9,12$ & 100 & - & - & - & - & 35 \\
10,11 & 117 & - & - & - & - & - \\
14 & - & - & - & - & - & 47 \\
16 & 11 & - & - & - & - & 23 \\
15 & - & - & - & - & - & 15 \\
13 & 61 & - & - & - & - & 11 \\
\hline
\end{tabular}

Table 17 A RURAL LAND USE MODEL FOR THE SEDBERGH AREA: STRATEGY: MEAT OPTIMISATION (DETAILED LAND USE PATTERN PROPOSED BYTHE MODEL)

\begin{tabular}{lcccccc}
\hline $\begin{array}{l}\text { Land } \\
\text { class } \\
\text { group }\end{array}$ & Forestry & $\begin{array}{c}\text { Specialist } \\
\text { dairy }\end{array}$ & $\begin{array}{c}\text { Mainly } \\
\text { dairy }\end{array}$ & \multicolumn{3}{c}{ Livestock rearing } \\
\hline $5-8$ & 72 & - & - & - & - & - \\
$1-4,9,12$ & - & - & - & - & - & 185 \\
10,11 & - & - & - & - & - & 117 \\
14 & 47 & - & - & - & - & - \\
16 & 34 & - & - & - & - & - \\
15 & - & - & - & - & - & 15 \\
13 & 48 & - & - & 14 & 10 & - \\
\hline
\end{tabular}

This concentration is a reflection of the limited number of decision variables considered by the model at this stage. The more subjectively defined resources such as highly valued landscape and wildlife areas, the economics of land use, and the personal preferences of land users have not been considered. The optimum outputs detailed in Table 18, from the new land use patterns of Tables 16 and 17, take into account the optimised output and the output from the land that has been excluded from the optimising part of the model, ie land in SSSIs, etc. These outputs will probably change when the more subjective criteria are used to evaluate each strategy.

Table 18 A RURAL LAND USE MODEL FOR THE SEDBERGH AREA: A COMPARISON OF TWO STRATEGIES WITH PRESENT OUTPUTS AND INPUTS

\begin{tabular}{lccc}
\hline Output/input & $\begin{array}{c}\text { Present } \\
\text { level }\end{array}$ & $\begin{array}{c}\text { Timber } \\
\text { optimisation }\end{array}$ & $\begin{array}{c}\text { Meat } \\
\text { optimisation }\end{array}$ \\
\hline Timber (m³/annum) & 100 & 26,664 & 1,396 \\
Meat (tonnes/annum) & 555.9 & 561.6 & 626.9 \\
Food energy & 29.8 & 31.8 & 32.5 \\
$\quad$ (TJ/annum) & 45,583 & 62,330 & 49,427 \\
Labour (SMD/annum) & 8,720 & 8,720 \\
Milk (tonnes/annum) & 8,720 & 60.5 & 60.5 \\
Wool (tonnes/annum) & 60.5 & &
\end{tabular}

STRATEGY 1 - TIMBER

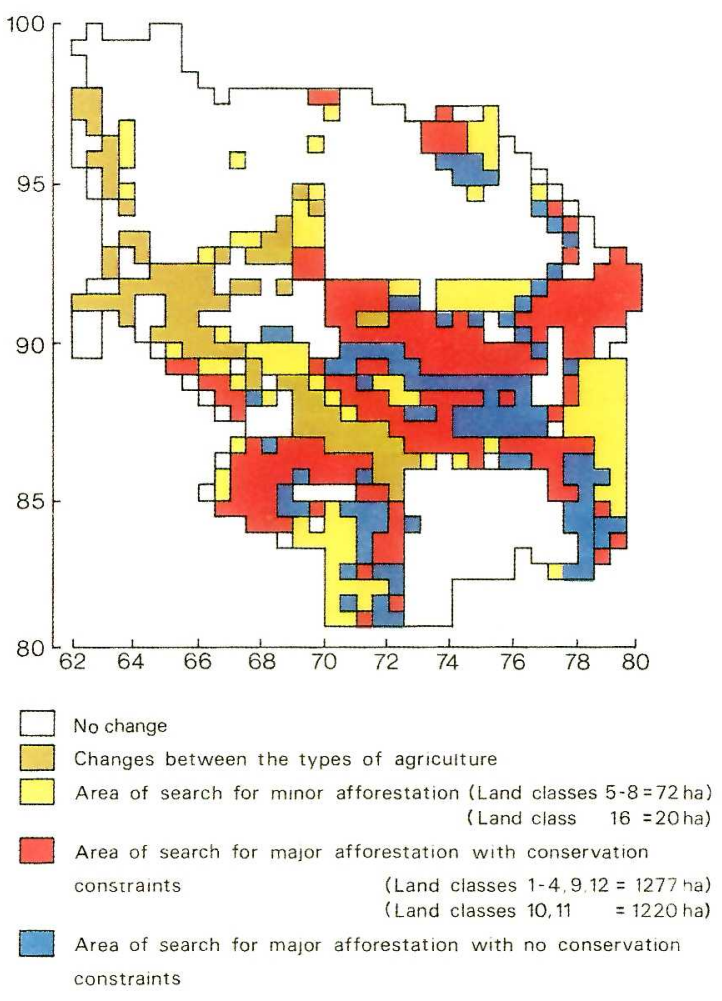

Figure 11 Changes proposed by the land use model when optimising for timber outputs in the Sedbergh area. From Smith and Budd (1982) 


\section{Stage 4: The evaluation of the alternative strategies against criteria not used initially to define them}

The alternative strategies generated at stage 3 are based on the physical potential of the land for different types of farming and forestry. The linear program allocates grid squares from each land class to land uses so as to optimise the desired output given a series of constraints. The outputs obtained are not only theoretical maxima; given the constraints, they are also unrealistically high values if the less easily quantifiable constraints are considered such as landscape and wildlife conservation and informal countryside recreation. An indication of how these constraints might be incorporated into the modelling process is given here for the Sedbergh area. The social and economic aspects of forestry and farming, particularly at the farm level, are not considered, as it is difficult to relate them to a grid square framework. However, some economic criteria have been included by Budd (1980) in her appraisal of the model.

The resource data for agricultural and forestry production are based upon the yields to be expected from standard management. Changes resulting in greater productivity are easily catered for in the model by adjusting the appropriate output coefficients. However, the present and proposed land use patterns bring with them associated values, eg landscape, wildlife and informal recreation values, which have an element of subjectivity in their assessment and are usually more easily assessed for the present land use pattern. Values associated with proposed future patterns are not only dependent upon the pattern itself, but also upon just how that pattern is brought about. Therefore, it is difficult to derive a table of coefficients to show the conservation values attributable to a land class under each of the land uses being considered.

An objective method for assigning landscape values to grid squares has been developed by the Centre for Urban and Regional Research (1976), and was used in the Sedbergh area to give 2 landscape values to the land classes: one for the land class itself and one for the views from that land class. Informal recreation values were based on the landscape values and an assessment of the accessibility of each land class (Smith \& Budd 1982). The resultant map delimited areas with high present-day landscape and recreation values. A map of nature conservation values in the area was provided by the Nature Conservancy Council. Only 220 of the 902 grid squares did not have high scores for any of the conservation and recreation values (Table 19). The 682 grid squares impose considerable limitations on the amount of land available for major afforestation, reducing it to about $50 \%$ of the area required by the forestry optimisation (Figure 11 ).
The subjective nature of these conservation values, especially the fact that a large element of the landscape value of a grid square in an upland area is contributed by the surrounding grid squares, has restricted the use of these values to a separate stage in the formulation of strategies. These problems will remain for the landscape and recreation values. However, nature conservation values based on the diversity, naturalness and rarity of the ecosystems within the land classes should be capable of being defined within the context of a study area. These values could then be incorporated into stage 3 of the model. Highly valued areas based upon national criteria outside the context of a given study area, eg Sites of Special Scientific Interest, would have to remain in stage 4 of the model.

The model proposals for each optimisation are shown in map form as differences between the present and the proposed land use pattern (Figure 11). These differences are classified into 3 categories: area of search for major afforestation; area of search for minor afforestation; area of change within agriculture. The model simplifies the agricultural land use pattern in its search for an optimum solution. Therefore, the changes proposed by each strategy within agriculture are complex and difficult to illustrate in map form. Changes proposed within agriculture are not likely to affect the associated conservation and recreation values, as the detail of the field pattern and vegetation is likely to be the same under each of the types of farming. Changes are only likely when rough grassland with the potential to become good inbye land has this potential taken up. Furthermore, the identification of general areas of search is implicit in the random sampling used to characterise the land classes. This interpretation of the proposed land use pattern is as necessary at this stage as it is at stages 1 and 2 .

Table 19 CONSEPVATION AND RECREATION VALUES IN THE SEDBERGH AREA

\begin{tabular}{lc}
\hline & $\begin{array}{c}\text { No. of grid } \\
\text { squares with } \\
\text { high scores }\end{array}$ \\
\hline Recreation & 144 \\
Landscape & 260 \\
Nature conservation & 34 \\
Landscape and recreation & 180 \\
Landscape and nature conservation & 34 \\
Recreation and nature conservation & 17 \\
Landscape, recreation and nature conservation & 13 \\
No high scores & 220 \\
\hline
\end{tabular}




\section{Discussion}

In any new technique, there is room for improvement. The initial use of a $1 \mathrm{~km}^{2}$ grid has varied from $\frac{1}{4} \mathrm{~km}^{2}$ to $100 \mathrm{~km}^{2}$ to suit the areas being surveyed (Pilling $\mathrm{et}$ al. 1978; ITE 1978). It has been found that estimates of the total amount of an ecological resource are not unduly affected by $\frac{1}{4} \mathrm{~km}^{2}$ or $1 \mathrm{~km}^{2}$ grid sizes. The differences lie in the predicted distributions, when the smaller grid size enables greater accuracy to be obtained. This use of standard grids enables direct comparisons to be made between a national classification and a regional one, which is facilitated if the same grid size is used for both. In this context, the national land classification being developed at the 1 $\mathrm{km}^{2}$ scale (Bunce 1979) will enable those areas with their own land classifications, eg Cumbria, Lancashire, Gwynedd, Yorkshire Dales National Park, to be directly related to the national situation.

The specific map attributes used have changed from presence/absence data for all conceivable attributes (Bunce \& Smith 1978) to area measures of the most important ones. Geological data are particularly important in this respect (Pilling et al. 1978), assisting considerably in the direct interpretation of the land classes from the map data alone (Smith \& Harper 1978). Further improvements in the method of cluster analysis used to derive the land classes will be included in future studies. In this respect, the use of TWINSPAN (Hill 1979), a modified form of indicator species analysis, will assist in the direct interpretation of the land classes.

Use of the land classes as sample strata will only be successful if the resource being assessed is linked to the geology, topography or land use of the area in question. The hills and uplands classification of the Ministry of Agriculture (Cowie personal communication) and the Forestry Commission site classifications (Busby 1974) are based upon these criteria. They aim to guide farm and forest management through an assessment of the restrictions imposed on production by the soils, topography and climate. The use of the land classification for such assessments is a further development along these lines enabling comparisons to be made between different types of land use.

The use of all the land classes for the sample survey of an area has been the standard approach. It has been modified by Bunce (personal communication) who has used only those land classes which contain lowland features in the Yorkshire Dales (Bunce \& Bunce 1980) for a survey of lowland grasslands. However, having chosen the sample squares from each land class, the method of survey adopted depends upon the purpose of the survey. No one method is best for all eco- systems, soils, or land uses. The differences between point sampling and complete surveys have been outlined already. Their successful application depends not only upon the sample size but also upon the use of unambiguous criteria. One of the most common functions of ecological surveys is to provide the basic information for nature conservation assessments. The subjective element in such assessments necessitates a 2-stage approach, if the land classes are to predict the location of areas likely to contain highly valued ecosystems. The first stage is the objective assessment of the vegetation component of these ecosystems, using either point samples to erect a vegetation classification or a vegetation key developed from such data. The production of such keys for Great Britain is the aim of the national vegetation classification (Rodwell 1976). Their use should enable complete surveys of grid squares to be carried out rapidly and objectively, thereby enabling the infrequent ecosystems to be properly measured. Criteria such as diversity, naturalness, and rarity (Ratcliffe 1977) can be used at the second stage to value the collection of ecosystems characteristic of each land class. However, such valuations can result in the same value being given to land classes of very different ecological character. Their interpretation must therefore rest on an analysis of the component ecosystems; hence, the 2-stage approach.

Most of the development work on this type of land classification has taken place in the uplands of Great Britain. Land use, geology and topography combine to produce recognisable units with distinctive characteristics. The question as to whether or not the technique can be applied to the lowlands has yet to be answered. Personal choice is important in land use decisions within agriculture (Ibery 1979). A farmer's main aim is first to obtain a secure and stable farm business. Once the essential factors for the achievement of security are obtained, farmers are influenced more strongly by social and personal considerations, and they choose to work with an enterprise that gives the most satisfaction. In the lowlands, a farmer has considerable flexibility in the type of farming he employs. Unlike the uplands, he is not very restricted by the natural environment. The resultant impact upon the landscape can mask variations in the natural environment of the lowlands, superimposing a "uniform" landscape upon an originally heterogenous one (Westmacott \& Worthington 1974). This may result in a poor correlation between the land classes and the ecosystems on the ground. Furthermore, the topographic extremes in upland areas are important in differentiating between the land classes, and the reduced topographical range in the lowlands may 
similarly reduce the association between land classes and ecosystems. The linear programming model used to generate alternative rural land use strategies may then be inappropriate in the lowlands when economic and not environmental constraints dictate the overall land use pattern. The same may be true of urban areas.

However, the use of land classification techniques in the lowlands is not without promise. The Solway coast study showed that a land classification could be obtained which reflected the variation in lowland ecosystems (Smith \& Harper 1978). Geological map characteristics have proved important in this context, and they should, therefore, always be included in the basic data for any lowland land classification. The production of land classes by indicator species analysis (Hill et al. 1975) involves a new ordination at each stage. Therefore, the main environmental trends should be recognised as long as the appropriate data have been collected. The success of the Cumbria land classification rests not only in its separation of upland and lowland, but in its recognition of land classes within the lowland areas based on their differing geology and small associated differences in topography. The strong correlation between tree cover and land class is essentially a lowland phenomenon.

Economic criteria can be incorporated into the model as an output to be optimised, and Budd (1980) has used such additional data to investigate many strategies for land use in the Sedbergh area. The sensitivity of the resultant land use patterns to errors in the data was tested in a further study of the model's limitations. The value of the model lies in this ability to test many strategies and their sensitivity to errors in the data used. Constraining the model to present limitations on land use produced a proposed land use pattern (Figure 11) which conformed to that which was expected. This enables greater faith to be placed in the model's answers when it is used to explore more extreme strategies.

At this stage in its development the technique has shown that it can provide a framework for rural planning in the upland regions of Great Britain. However, there is no co-ordinating body responsible for the detailed planning of rural land use. Rather, these responsibilities lie with different organisations each concerned with a particular use and attitude towards it. The Nature Conservancy Council, for instance, has statutory. responsibility for nature conservation, but there are also voluntary bodies, such as the Royal Society for the Protection of Birds, closely concerned with the wildlife implications of farming and forestry. The Sedbergh Rural Land Use Study has shown how such disparate bodies can work together, both as technicians and politicians, once a framework has been provided for their discussions. It differs from similar studies, eg North Riding Pennines Study (North Riding Pennines Study Working Party 1975), in that it asks those involved to work to a specific framework rather than each organisation submitting their own report, each with its own reference system, not easily compared with others. The data required by the linear programming model make the assumptions explicit and hence liable to testing. There have, therefore, been educational problems in the use of the land classifications. Whilst the technique is simple in principle, its implementation is complex and it asks a lot of its users. They have to invest a considerable amount of time in learning about the potentials and problems involved before getting a return. This problem was foreseen by Bishop (1978) when he concluded that the best solution to the problem of presenting results lay in a complete understanding of the model and its output. Failing this, contact between the decision-maker and the modeller must be frequent whenever results are being used for planning rural land use. 


\section{Bibliography}

Avery, B. W. 1973. Soil classification in the Soi Survey of England and Wales. J. Soil Sci., 24, 324-338.

Bendelow, V. C. \& Carroll, D. M. 1978. The soils in the parishes of Sedbergh, Garsdale and Dent, Cumbria. Report to Cumbria County Council by the Soil Survey of England and Wales. (Unpublished).

Bibby, J. S. \& Mackney, D. 1969. Land use capability classification. (Technical monograph no. 1). Harpenden: Soil Survey.

Bishop, I. 1978. Land use in rural Cumbria - a linear programming model. (Merlewood research and development paper no. 75). Grange-over-Sands: Institute of Terrestial Ecology.

Budd, R. 1980. The revised land use model, its structure and application to the Sedbergh district. Report to the Sedbergh Rural Land Use Study steering group. (Unpublished).

Bunce, R. G. H. 1979. Ecological survey of Britain. Annu. Rep. Inst. terr. Ecol. 1978, 74-75.

Bunce, R. G. H. \& Bunce, F. M. 1980. Land classification for ecological survey. Bainbridge: Yorkshire Dales National Park Committee.

Bunce, R. G. H., Morrell, S. K. \& Stel, H. E. 1975. The application of multivariate analysis to regional survey. J. environ. Manage., 3, 151-166.

Bunce, R. G. H. \& Shaw, M. W. 1973. A standardised procedure for ecological survey. $J$. environ. Manage., 1, 239-258.

Bunce, R. G. H. \& Smith, R. S. 1978. An ecological survey of Cumbria. Kendal: Cumbria County Council \& Lake District Special Planning Board.

Busby, R. J. M. 1974. Forest site yield guide to upland Britain. Forest Rec., Lond., no. 97.

Centre for Urban Regional Research. 1976. Landscape evaluation: report of the landscape evaluation research project to the Countryside Commission for England and Wales. Manchester: University of Manchester.

Countryside Review Committee. 1976. The countryside - problems and policies: a discussion paper. London: HMSO.
Department of the Environment. 1974. Nature conservation. (Circular 161/74). London: DoE.

Department of the Environment \& Welsh Office. 1976. Report of the National Park Policies Review Committee. (Circular 1976/4). London: HMSO.

Department of the Environment \& Welsh Office. 1977. Nature conservation and p/anning. (Circular 1977/108). London: HMSO.

Department of the Environment \& Welsh Office. 1979. The town and country planning act 1971. Memorandum on structure and local plans. (Circular 1979/4). London: HMSO.

Edington, J. M. \& Edington, M. A. 1977. Ecology and environmental planning. London: Chapman \& Hall.

Fisher, R. A. \& Yates, F. 1943. Statistical tables for biological, agricultural and medical research. Edinburgh: Oliver \& Boyd.

Hill, M. O. 1973. Reciprocal averaging: an eigenvector method of ordination. J. Ecol., 61, 237- 249.

Hill, M. O. 1979. TWINSPAN - a FORTRAN program for arranging multivariate data in an ordered two-way table by classification of the individuals and attributes. Ithaca, N.Y.: Section of Ecology and Systematics, Cornell University.

Hill, M. O., Bunce, R. G. H. \& Shaw, M. W. 1975. Indicator species analysis: a divisive polythetic method of classification and its application to a survey of native pinewoods in Scotland. J. Ecol., 63, 597-613.

Ibery, B. W. 1979. Decision making in agriculture: a case study of NE Oxfordshire. Reg. Stud., 13, 199-210.

Institute of Terrestrial Ecology. 1978. Upland land use in England and Wales. (CCP 111). Cheltenham: Countryside Commission.

Jeffers, J. N. R. 1978. An introduction to systems analysis: with ecological applications. London: Edward Arnold.

Jones, I. 니. 1967. Studies on hill land in Wales. Aberystwyth: Welsh Plant Breeding Station.

Milner, C. 1978. Shetland ecology surveyed. Geogrl Mag., Lond., 50, 730-736. 
Nix, J. 1978. Farm management pocketbook. 9th ed. Ashford: School of Rural Economics and Related Studies, Wye College.

North Riding Pennines Study Working Party. 1975. North Riding Pennines Study. Northallerton: North Riding County Council.

Pilling, R., Gibson, R., Chipperfield, E., Watts, A., Smith, R. S. \& Bunce, R. G. H. 1978. An ecological survey of the Sedbergh region of the Yorkshire Dales National Park, and of the Arnside/Silverdale Area of Outstanding Natural Beauty. Report to the County Planning Officer, Cumbria County Council. IUnpublished).

Ratcliffe, D. A. 1977. A nature conservation review: the selection of biological sites of national importance to nature conservation in Britain. London: Cambridge University Press.

Rodwell, J. 1976. National vegetation classification. Bull. Br. ecol. Soc., 7 (2), 6-7.

Shimwell, D. W. 1971. The description and classification of vegetation. London: Sidgwick \& Jackson.
Smith, R. S. 1977. A tree cover survey of Cumbria. Report to the County Planning Officer, Cumbria County Council. (Unpublished).

Smith, R. S. \& Budd, R. 1982. Land use in upland Cumbria: a model for forestry/farming strategies in the Sedbergh area. (Research monograph in technological economics no. 4). Stirling: Technological Economics Research Unit, University of Stirling.

Smith, R. S. \& Harper, S. 1978. A land classification for the Solway Coast Area of Outstanding Natural Beauty. Report to the County Planning Officer, Cumbria County Council. (Unpublished).

Taylor, J. 1978. The broadleaved woodlands of the Lake District. Kendal: Lake District Special Planning Board.

Webster, R. A. 1977. Quantitative and numerical methods in soil classification and survey. Oxford: Clarendon.

Westmacott, R. \& Worthington, T. 1974. New agricultural landscapes. (CCP 76). Cheltenham: Countryside Commission. 


\section{Annex 1: The agricultural and forestry productivity of the land classes in the Sedbergh area}

\begin{abstract}
ASSUMPTIONS USED TO CALCULATE THE GRAZING
LIVESTOCK UNITS ASSOCIATED.WITH EACH LAND CAPABILITY CLASS

Capability Class 4 Land with moderately severe limitations that restrict the choice of crops and/or require management. Climatic disadvantages combine with other limitations to restrict the choice and yield of crops and increase risks. The main crop is grass, with cereals and forage crops as possible alternatives where the increased hazards can be accepted. It occupies 21.27 ha or $10 \%$ of the area. In estimating the agricultural outputs, this land was assumed to grow grass leys capable of carrying an average stocking rate of dairy cows, ie 1.9 cows per hectare. With dairy cows equivalent to one grazing livestock unit, this stocking rate is $47.5 \mathrm{GLU} / 25$ ha. Allowing $15 \%$ of the area for farm buildings, roads, boundaries, etc, this rate becomes $40.4 \mathrm{GLU} / 25$ ha, to give a coefficient of 0.404 . The percentage frequency of capability class 4 land in each land class is multiplied by this coefficient to give the GLUs per land class dependent upon this capability class.
\end{abstract}

Capability Class 5 Land with severe limitations that restrict its use to pasture, forestry and recreation. High rainfall, exposure and a restricted growing season prohibit arable cropping, although mechanised pasture improvements are feasible. The land has a wide range of capability for forestry and recreation. It occupies $5357 \mathrm{ha}$, or $25.2 \%$ of the area. In estimating the agricultural outputs, this land was assumed to be permanent pasture not capable of supporting the intensive grassland production of capability class 4 land. Its most intensive use is probably single suckling upland beef production with a stocking rate of one cow per 0.9 hectare. With beef cows equivalent to $0.75 \mathrm{GLU}$ and a $15 \%$ allowance for land under buildings, roads, etc, this rate gives $17.7 \mathrm{GLU}$ per $25 \mathrm{ha}$. The coefficient of 0.177 is used in the same way as for capability class 4 land.

Capability Class 6 Land with very. severe limitations that restrict use to rough grazing, forestry and recreation. The land has limitations which are sufficiently severe to prevent the use of machinery for pasture improvement. Very steep ground which has some sustained grazing value is included. It occupies 12,776 ha, or $60 \%$ of the area. In estimating the agricultural outputs, this land was assumed to be rough grassland only capable of supporting hill sheep for 10 months, with lambs in the 6 summer months. The varied grassland types support on average 0.45 sheep/ hectare and give a lambing percentage of $80 \%$ ( Nix 1978; Jones 1967). With $0.06 \mathrm{GLU}$ per hill sheep and $0.04 \mathrm{GLU}$ per lamb, this rate gives $3.63 \mathrm{GLU} / 25$ ha of capability class 6 land. The coefficient of 0.0363 is used as above.

Capability Class 7 Land with extremely severe limitations that cannot be rectified. Exposed situations, protracted snow cover and a short growing season preclude forestry though a poor type of rough grazing may be available for a few months. It occupies 1039 ha, or $4.9 \%$ of the area. In estimating the agricultural outputs, this rough grassland was assumed to be virtually worthless as grazing land.

The mean potential grazing livestock units attributable to each agricultural capability class in each land class (Table 20) show a gradual increase in potential GLUs from the mountain top land classes to those on the lower middle slopes, with an abrupt 3-fold increase in those in the valley bottoms. As a check on the relevance and accuracy of these figures, they have been compared with an estimate of the present GLUs based on the present vegetation types (Table 21) and the present livestock numbers taken from the 1976 parish statistics provided by the Ministry of Agriculture (Table 22). The difference between present and potential GLUs gives an indication of how much of the potential is taken up. On the basis of their vegetation character, 6 land classes appear to have a greater present output than they have potential. For land classes 4,6 and 7 , this disparity is due to the fact that the capability class 7 land has been assigned GLUs for the rough grazing in the calculation for present GLUs.

Table $2 O$ POTENTIAL GRAZING LIVESTOCK UNITS IN THE SEDBERGH AREA

\begin{tabular}{|c|c|c|c|c|c|c|}
\hline & \multirow{2}{*}{$\begin{array}{l}\text { Land } \\
\text { class }\end{array}$} & \multicolumn{4}{|c|}{ GLUs* in each capability class } & \multirow{2}{*}{$\begin{array}{l}\text { Total } \\
\text { GLUs }\end{array}$} \\
\hline & & 4 & 5 & 6 & 7 & \\
\hline \multirow{4}{*}{$\begin{array}{l}\text { Mountain } \\
\text { tops }\end{array}$} & 5 & - & - & 2.5 & $\ldots$ & 2.5 \\
\hline & 6 & - & - & 2.0 & - & 2.0 \\
\hline & 8 & - & 2.1 & 3.2 & - & 5.3 \\
\hline & 7 & - & 0.1 & 3.3 & - & 3.4 \\
\hline \multirow{4}{*}{$\begin{array}{l}\text { Upper } \\
\text { middle } \\
\text { slopes }\end{array}$} & 2 & - & 1.7 & 3.3 & - & 5.0 \\
\hline & 1 & - & 2.8 & 3.1 & - & 5.9 \\
\hline & 3 & - & 0.9 & 3.5 & - & 4.4 \\
\hline & 4 & - & 2.6 & 3.1 & - & 5.7 \\
\hline \multirow{4}{*}{$\begin{array}{l}\text { Lower } \\
\text { middle } \\
\text { slopes }\end{array}$} & 9 & 0.8 & 2.4 & 3.1 & - & 6.3 \\
\hline & 12 & - & 4.1 & 2.8 & - & 6.9 \\
\hline & 11 & 0.3 & 7.4 & 2.1 & - & 9.8 \\
\hline & 10 & 0.3 & 6.0 & 2.4 & - & 8.7 \\
\hline \multirow{4}{*}{$\begin{array}{l}\text { Valley } \\
\text { bottoms }\end{array}$} & 14 & 19.0 & 9.0 & 0.1 & - & 28.1 \\
\hline & 16 & 5.1 & 12.5 & 0.6 & - & 18.2 \\
\hline & 15 & 11.4 & 12.0 & 0.2 & 一 & 23.6 \\
\hline & 13 & 30.5 & 4.3 & - & - & 34.8 \\
\hline
\end{tabular}

*GLUs: Grazing Livestock Units 
Tab/e 21 TOTAL GRAZING LIVESTOCK UNITS IN THE SEDBERGH AREA

\begin{tabular}{|c|c|c|c|c|}
\hline & Land class & $\begin{array}{c}\text { Number of } \\
\text { grid } \\
\text { squares }\end{array}$ & $\begin{array}{c}\text { Present } \\
\text { GLUs* from } \\
\text { vegetation } \\
\text { data }\end{array}$ & $\begin{array}{l}\text { Potential } \\
\text { GLUs* from } \\
\text { capability } \\
\text { data }\end{array}$ \\
\hline \multirow{4}{*}{$\begin{array}{l}\text { Mountain } \\
\text { tops }\end{array}$} & 5 & 77 & 282 & 191 \\
\hline & 6 & 35 & 131 & 69 \\
\hline & 8 & 40 & 168 & 210 \\
\hline & 7 & 41 & 173 & 142 \\
\hline \multirow{4}{*}{$\begin{array}{l}\text { Upper } \\
\text { middle } \\
\text { slopes }\end{array}$} & 2 & 44 & 246 & 218 \\
\hline & 1 & 62 & 285 & 363 \\
\hline & 3 & 29 & 109 & 125 \\
\hline & 4 & 51 & 198 & 292 \\
\hline \multirow{4}{*}{$\begin{array}{l}\text { Lower } \\
\text { middle } \\
\text { slopes }\end{array}$} & 9 & 51 & 527 & 319 \\
\hline & 12 & 96 & 438 & 662 \\
\hline & 11 & 87 & 818 & 848 \\
\hline & 10 & 80 & 771 & 698 \\
\hline \multirow{4}{*}{$\begin{array}{l}\text { Valley } \\
\text { bottoms }\end{array}$} & 14 & 48 & 1339 & 1348 \\
\hline & 16 & 67 & 488 & 1223 \\
\hline & 15 & 21 & 351 & 493 \\
\hline & 13 & 72 & 1809 & 2510 \\
\hline Totals & & 901 & 8133 & 9711 \\
\hline
\end{tabular}

Table 22 LIVESTOCK NUMBERS IN THE SEDBERGH AREA (1976)

\begin{tabular}{|c|c|c|}
\hline Livestock & Number & GLUs* \\
\hline Cows: dairy & 2,119 & 2,119 \\
\hline beef & 1,404 & 1,053 \\
\hline Heifer: dairy & 697 & 697 \\
\hline beef & 218 & 164 \\
\hline Bulls & 91 & 64 \\
\hline Cattle: 2 yrold & 28 & 22 \\
\hline $1-2$ yrs & 310 & 202 \\
\hline $6-12$ mths & 262 & 89 \\
\hline under 6 mths & 1,499 & 255 \\
\hline Breeding ewes & 37,049 & 2,223 \\
\hline Draft and cast ewes & 785 & 47 \\
\hline Lambs & 31,753 & 1,969 \\
\hline Rams & 552 & 44 \\
\hline
\end{tabular}

Total GLUs*

8,948

*Grazing Livestock Units

Land classes 2, 9 and 10 probably over-estimate the amount of improved pasture. The present stocking levels, as given by the Ministry of Agriculture, Fisheries and Food, represent 8948 GLUs (Table 22). This level is $10 \%$ greater than estimated present GLUs and $8 \%$ less than the potential GLUs. The estimate is within acceptable limits and could be accounted for by hay imports.

The details of the conversion of these grazing livestock units to dairy, beef cattle and sheep products such as milk, meat and wool are given in Smith and Budd (1982). The conversions are based on data presented by Nix (1978). The potential amount of dairy products from each land class is given here as an example of the type of calculations involved in these conversions, and to show the many assumptions that are explicitly made.
The average yield of milk per cow is 4500 litres/annum, with 3750 litres/annum/cow as a low yield. This comes from $80 \%$ of the herd, the remaining animals in the herd being replacements for those cows currently producing this milk. About $75 \%$ of a replacement unit is required for each cow in the herd, ie one calf, yearling and heifer for every 4 cows (including calved heifers), allowing a few extra calves reared to allow for culling. At average stocking rates for both, this means one hectare devoted to followers for every 3 hectares for cows. However, since surplus young stock are often reared, and frequently the stocking rate is less intensive, the ratio is often $1: 2.5$. Therefore, only $71.4 \%$ of the GLUs in each land class are used for milk production. Dairy farming only occurs on agricultural capability classes 4 and 5 . Therefore, each GLU from capability class 4 land gives 3215 litres milk/annum, and each GLU from capability class 5 land gives 2678 litres milk/annum. This gives a potential milk production from each land class which varies from zero, where agricultural capability classes 4 and 5 are absent, up to 109,700 litres per annum in land class 13 (Table 23).

It is assumed that any male calves are immediately sold, ie there is no meat production from dairying apart from cull cows. Any such enterprises on a dairy farm are considered to be a subsidiary beef enterprise. With $20 \%$ of the herd being replaced each year and a dressed carcass weight of $225 \mathrm{~kg}$ (Bishop 1978); one GLU in a land class is equivalent to $38.9 \mathrm{~kg}$ meat from cull cows. The food energy conversions for beef meat and milk are $0.01017 \mathrm{GJ} / \mathrm{kg}$ and $0.00272 \mathrm{GJ} /$ litre respectively (Table 23 ).

Table 23 POTENTIAL DAIRY FARMING PRODUCTION PER SEDBERGH LAND CLASS*

\begin{tabular}{|c|c|c|c|c|c|c|}
\hline & \multirow[t]{2}{*}{$\begin{array}{l}\text { Land } \\
\text { class }\end{array}$} & \multicolumn{3}{|c|}{$\begin{array}{l}\text { Milk production } \\
\text { (litres/annum) }\end{array}$} & \multirow{2}{*}{$\begin{array}{c}\text { Meat pro- } \\
\text { duction } \\
\text { (kg/ann/ } \\
25 \text { ha) }\end{array}$} & \multirow{2}{*}{$\begin{array}{l}\text { Total } \\
\text { food } \\
\text { energy } \\
\text { (TJ/ann/ } \\
25 \text { ha) }\end{array}$} \\
\hline & & $\begin{array}{l}\text { Capability } \\
\text { class } 4\end{array}$ & $\begin{array}{l}\text { Capability } \\
\text { class } 5\end{array}$ & Total & & \\
\hline \multirow{4}{*}{$\begin{array}{l}\text { Mountain } \\
\text { tops }\end{array}$} & 5 & - & $\ldots$ & - & - & - \\
\hline & 6 & - & - & - & - & - \\
\hline & 8 & - & 5,490 & 5,490 & 80 & 15.7 \\
\hline & 7 & - & 320 & 320 & 5 & 0.9 \\
\hline \multirow{4}{*}{$\begin{array}{l}\text { Upper } \\
\text { middle } \\
\text { slopes }\end{array}$} & 2 & - & 4,550 & 4,550 & 66 & 13.1 \\
\hline & 1 & - & 7,500 & 7,500 & 109 & 21.5 \\
\hline & 3 & - & 2,280 & 2,280 & 33 & 6.5 \\
\hline & 4 & - & 7,070 & 7,070 & 103 & 20.3 \\
\hline \multirow{4}{*}{$\begin{array}{l}\text { Lower } \\
\text { middle } \\
\text { slopes }\end{array}$} & 9 & 2,470 & 6,450 & 8,920 & 124 & 25.5 \\
\hline & 12 & - & 11,030 & 11.030 & 160 & 31.6 \\
\hline & 11 & 900 & 19,760 & 20,660 & 298 & 59.2 \\
\hline & 10 & 1,030 & 16,180 & 17,210 & 247 & 49.3 \\
\hline & 14 & 61,010 & 24,130 & 85,140 & 1,089 & 242.7 \\
\hline Valley & 16 & 16,490 & 33,590 & 50,080 & 687 & 143.0 \\
\hline \multirow[t]{2}{*}{ bottoms } & 15 & 36,470 & 32,000 & 68,470 & 906 & 195.5 \\
\hline & 13 & 98,130 & 11,570 & 109,700 & 1,356 & 312.2 \\
\hline
\end{tabular}

*Productivity data are given in terms of output per 25 ha as this was the grid size for the Sedbergh land classification 
The amount of dairy, beef cattle and sheep products from any land class depends upon the particular mix of enterprises on each farm. It is unlikely that a given land class will be devoted entirely to one enterprise. However, land classes 1-8 on the mountain tops and upper middle slopes are the exception to this rule as they are used almost exclusively for sheep rearing. The outputs from each land class are calculated for each type of farming in the Sedbergh area, from the relative proportions, based on GLUs, of the dairy, beef cattle and sheep enterprises.

A check on the overall accuracy of the agricultural productivity data was made by comparing the present outputs as shown by MAFF's parish returns for the area, against the predicted outputs. These latter were calculated from the productivity data and the known distribution of the types of farming amongst the land classes. The similarity between the 2 sets of output figures is considerable; the greatest difference is in the meat estimate (8.1\%) (Table 24).

Table 24 A COMPARISON OF THE PRESENT AND PREDICTED OUTPUTS FROM THE SEDBERGH AREA

\begin{tabular}{lrrr}
\hline Output & $\begin{array}{r}\text { Present } \\
\text { (tonnes) }\end{array}$ & $\begin{array}{c}\text { Predicted } \\
\text { (tonnes) }\end{array}$ & $\begin{array}{c}\text { Difference } \\
\text { (\%) }\end{array}$ \\
\hline Meat & 561 & 606 & +8.1 \\
Milk & 8,741 & 8,634 & -1.2 \\
Wool & 60 & 58 & -3.6 \\
\hline
\end{tabular}

The timber potential of each land class was assessed from 8 randomly selected grid squares. The local Forestry Commission District Officer suggested the best species to plant and the area of plantable land. Maximum timber yield of the most appropriate species was then used as the basis for the assessment. The height limit for productive forestry was taken as 1500 $\mathrm{ft}$, but varied slightly according to the situation. The main species chosen, based on soils, vegetation and altitude, were Sitka spruce, Norway spruce, larch, Douglas fir, lodgepole pine and several broadleaved species. Yield classes were assigned to each species, in each sample square from published data (Busby 1974), and by field visits to existing woodlands. The average volume production per $\frac{1}{4} \mathrm{~km}^{2}$ per annum was calculated; the product of area and yield class for each species gives the output in $\mathrm{m}^{3} / \mathrm{ha} /$ annum. The total production was reduced to $85 \%$ to allow for nonproductive areas. The total yield and species composition of each land class is given in Tables 25 and 26.

Labour inputs to achieve the agricultural outputs were based on the number of standard man days needed for different types of animals and for the management of grass leys and permanent pasture; and on the proportion of each type of farming devoted to dairy beef and sheep products. Forest labour requirements were given by Bishop (1978) as $0.77 \mathrm{SMD} /$ annum/hectare for establishment, protection and maintenance of the forest, and as $0.455 \mathrm{SMD} / \mathrm{m}^{3} /$ annum for logging.
Table 25 POTENTIAL FOREST AREA AROUND SEDBERGH (HECTARES PER GRID SQUARE IN EACH LAND CLASS)

\begin{tabular}{|c|c|c|c|c|c|c|c|c|c|}
\hline & $\begin{array}{l}\text { Land } \\
\text { class }\end{array}$ & $\begin{array}{l}\text { Sitka } \\
\text { Spruce }\end{array}$ & $\begin{array}{l}\text { Lodge } \\
\text { pole } \\
\text { pine }\end{array}$ & $\begin{array}{l}\text { Do } \\
\text { Norway } \\
\text { spruce }\end{array}$ & ouglas & Larch & $\begin{array}{c}\text { Broad } \\
\text { leaf } \\
\text { species }\end{array}$ & $\begin{array}{l}\text { Scots } \\
\text { pine }\end{array}$ & $\begin{array}{l}\text { Unpl } \\
\text { anted }\end{array}$ \\
\hline \multirow{4}{*}{$\begin{array}{l}\text { Mountain } \\
\text { tops }\end{array}$} & 5 & 0.4 & - & - & - & - & - & - & 24.6 \\
\hline & 6 & 0.1 & - & - & - & - & - & - & 24.9 \\
\hline & 8 & 5.8 & 0.5 & - & - & - & - & - & 18.7 \\
\hline & 7 & - & 0.4 & - & - & - & - & - & 24.6 \\
\hline \multirow{4}{*}{$\begin{array}{l}\text { Upper } \\
\text { middle } \\
\text { slopes }\end{array}$} & 2 & 14.1 & 1.4 & - & - & 0.5 & 0.4 & 1.0 & 7.6 \\
\hline & 1 & 17.5 & 4.0 & - & - & 0.8 & 0.1 & - & 2.6 \\
\hline & 3 & 12.1 & 8.0 & - & - & - & - & - & 4.9 \\
\hline & 4 & 13.1 & 4.9 & - & - & - & - & - & 7.0 \\
\hline \multirow{4}{*}{$\begin{array}{l}\text { Lower } \\
\text { middle } \\
\text { slopes }\end{array}$} & 9 & 11.5 & 4.2 & - & - & 1.4 & 0.8 & - & 7.1 \\
\hline & 12 & 14.6 & 4.1 & - & - & 1.0 & - & 0.1 & 5.2 \\
\hline & 11 & 13.5 & 5.9 & 1.1 & - & 1.6 & 0.9 & 1.0 & 1.0 \\
\hline & 10 & 14.6 & 3.0 & 0.5 & - & 1.4 & 0.4 & - & 5.1 \\
\hline \multirow{4}{*}{$\begin{array}{l}\text { Valley } \\
\text { bottoms }\end{array}$} & 14 & 5.3 & - & - & 1.0 & 11.0 & 6.5 & 一 & 1.2 \\
\hline & 16 & 16.6 & 2.6 & - & - & 2.5 & 1.5 & 0.6 & 1.2 \\
\hline & 15 & 8.0 & - & - & - & 11.4 & 5.0 & - & 0.6 \\
\hline & 13 & 2.0 & - & - & - & 13.5 & 7.1 & - & 2.4 \\
\hline
\end{tabular}

Table 26 POTENTIAL TIMBER PRODUCTION FROM PROPOSED PLANTING SCHEME IN THE SEDBERGH AREA

\begin{tabular}{|c|c|c|c|c|c|c|c|c|c|}
\hline \multirow[b]{2}{*}{$\begin{array}{l}\text { Land } \\
\text { class }\end{array}$} & & \multirow{2}{*}{$\begin{array}{c}\text { Total } \\
\text { prod- } \\
\text { uction } \\
\left(\mathrm{m}^{3} /\right. \\
\mathrm{m}^{2} \\
/ \mathrm{yr})\end{array}$} & \multicolumn{7}{|c|}{$\begin{array}{l}\text { Percentage contribution } \\
\text { to production by each species }\end{array}$} \\
\hline & & & $\begin{array}{l}\text { Sitka } \\
\text { spruce }\end{array}$ & $\begin{array}{l}\text { Lodge } \\
\text { pole } \\
\text { pine }\end{array}$ & $\begin{array}{c}\text { D } \\
\text { Norway } \\
\text { spruce }\end{array}$ & $\begin{array}{l}\text { Douglas } \\
y \text { fir }\end{array}$ & Is & $\begin{array}{c}\text { Broad } \\
\text { leaf } \\
\text { species }\end{array}$ & $\begin{array}{l}\text { Scots } \\
\text { pine }\end{array}$ \\
\hline \multirow{4}{*}{$\begin{array}{l}\text { Mountain } \\
\text { tops }\end{array}$} & 5 & 3 & 100.0 & - & - & - & - & - & - \\
\hline & 6 & 1 & 100.0 & - & - & - & - & - & - \\
\hline & 8 & 53 & 94.4 & 5.6 & - & - & - & - & - \\
\hline & 7 & 2 & - & 100.0 & - & - & - & - & - \\
\hline \multirow{4}{*}{$\begin{array}{l}\text { Upper } \\
\text { middle } \\
\text { slopes }\end{array}$} & 2 & 135 & 84.2 & 5.9 & - & - & 3.1 & 1.4 & 5.5 \\
\hline & 1 & 186 & 83.5 & 12.8 & - & - & 3.4 & 0.4 & - \\
\hline & 3 & 151 & 66.9 & 33.1 & - & - & - & - & - \\
\hline & 4 & 145 & 78.9 & 21.1 & - & - & - & - & - \\
\hline \multirow{4}{*}{$\begin{array}{l}\text { Lower } \\
\text { middle } \\
\text { slopes }\end{array}$} & 9 & 140 & 71.3 & 17.5 & - & - & 8.4 & 2.7 & - \\
\hline & 12 & 165 & 79.3 & 15.5 & - & - & 4.6 & - & 0.5 \\
\hline & 11 & 204 & 63.3 & 17.3 & 6.6 & - & 6.8 & 1.6 & 3.8 \\
\hline & 10 & 168 & 77.1 & 11.3 & 3.5 & - & 7.0 & 1.1 & - \\
\hline \multirow{4}{*}{$\begin{array}{l}\text { Valley } \\
\text { bottoms }\end{array}$} & 14 & 206 & 41.7 & - & - & 5.3 & 39.1 & 13.9 & - \\
\hline & 16 & 218 & 77.3 & 6.7 & - & - & 10.0 & 3.6 & 2.5 \\
\hline & 15 & 208 & 41.6 & - & - & - & 46.5 & 11.9 & - \\
\hline & 13 & 173 & 12.4 & - & - & - & 64.6 & 23.0 & - \\
\hline
\end{tabular}

The linear programming model allocates land uses to land classes to achieve the optimum output of a desired commodity, within the limits dictated by the chosen strategy. The land use to land class allocation may well be between land classes that differ in their productivity by only a small amount. The differences may be within the limits of error of the productivity estimates, which in this case appears to be in the region of $10 \%$. In optimising the land use/land class combinations, a very small productivity difference may be used by the model as the basis for the optimum combination. Such choices for Sedbergh are spurious when based on the differences of less than $10 \%$. Therefore, the land classes were amalgamated into 7 land class groups based on their agricultural and forestry production, ie: 
Group 1 Land classes 1, 2, 3, 4, 9, 12

Group 2 Land classes 5, 6, 7, 8

Group 3 Land classes 10, 11

Group 4 Land class 13

Group 5 Land class 14

Group 6 Land class 15

Group 7 Land class 16

These $\mathbf{7}$ groups differ in their overall productivity by at least $10 \%$. Their outputs of milk, meat, food energy, wool and timber, and the labour input necessary to achieve these outputs are given in Tables 27 to 32, for 5 types of farming and for forestry. Some of the outputs are mainly achieved by one land use, eg timber from forestry. Others are only obtained from certain land classes, eg milk from the lowland and some of the lower middle slope classes. The mixed nature of the types of farming, with livestock rearing (sheep), for example, having a proportion of dairy cows, means that most of the agricultural outputs can be obtained from each of the types of farming. However, each type of farming produces more of one output than the other types.

Table 27 MILK PRODUCTION COEFFICIENTS (litres/annum/25 ha)

\begin{tabular}{lcrrrrr}
\hline $\begin{array}{l}\text { Land class } \\
\text { group }\end{array}$ & $\begin{array}{c}\text { Forestry Specialist } \\
\text { dairy }\end{array}$ & Mainly & \multicolumn{3}{c}{ Livestock rearing } \\
& & & & & & \multicolumn{2}{c}{$\begin{array}{c}\text { Cattle } \\
\text { \& sheep }\end{array}$} & Sheep \\
\hline $1,2,3,4,9,12$ & 0 & 5970 & 4377 & 359 & 359 & 1269 \\
$5,6,7,8$ & 0 & 1258 & 923 & 76 & 76 & 267 \\
10,11 & 0 & 16397 & 12023 & 985 & 985 & 3484 \\
13 & 0 & 94995 & 69656 & 5704 & 5704 & 20184 \\
14 & 0 & 73734 & 54066 & 4427 & 4427 & 15666 \\
15 & 0 & 59295 & 43478 & 3560 & 3560 & 12598 \\
16 & 0 & 43333 & 31774 & 2602 & 2602 & 9207 \\
\hline
\end{tabular}

Table 28 MEAT PRODUCTION COEFFICIENTS (kg/annumi/25 ha)

\begin{tabular}{lrrrrrr}
\hline $\begin{array}{l}\text { Land class } \\
\text { group }\end{array}$ & $\begin{array}{r}\text { Forestry Specialist } \\
\text { dairy }\end{array}$ & Mainly & \multicolumn{3}{c}{ Livestock rearing } \\
& & & Cattle & \multicolumn{2}{c}{ Cattle } & Sheep \\
& & & & & \& sheep & \\
\hline $1,2,3,4,9,12$ & 0 & 134.0 & 194.0 & 327.4 & 333.4 & 306.0 \\
$5,6,7,8$ & 0 & 47.4 & 92.8 & 108.0 & 141.1 & 152.7 \\
10,11 & 0 & 310.7 & 376.2 & 767.5 & 692.1 & 569.3 \\
13 & 0 & 1444.4 & 1596.5 & 6943.1 & 5288.9 & 3327.7 \\
14 & 0 & 1160.8 & 1284.3 & 4939.9 & 3825.2 & 2491.8 \\
15 & 0 & 966.8 & 1071.1 & 4253.5 & 3280.4 & 2118.3 \\
16 & 0 & 737.1 & 823.6 & 2337.0 & 1905.6 & 1366.9 \\
\hline
\end{tabular}

Table 29 FOOD ENERGY PRODUCTION COEFFICIENTS (Giga joules/annum/25 ha)

\begin{tabular}{lrrrrrr}
\hline $\begin{array}{l}\text { Land class } \\
\text { group }\end{array}$ & $\begin{array}{r}\text { Forestry Specialist } \\
\text { dairy }\end{array}$ & $\begin{array}{c}\text { Mainly } \\
\text { dairy }\end{array}$ & \multicolumn{3}{c}{ Cattle $\begin{array}{c}\text { Livestock rearing } \\
\text { Cattle } \\
\text { \& sheep }\end{array}$} \\
& & & & & Sheep \\
\hline $1,2,3,4,9,12$ & 0 & 17.7 & 14.2 & 4.6 & 4.9 & 7.2 \\
$5,6,7,8$ & 0 & 4.0 & 3.7 & 1.5 & 2.0 & 2.7 \\
10,11 & 0 & 48.0 & 37.1 & 11.0 & 10.5 & 16.2 \\
13 & 0 & 273.8 & 207.6 & 87.7 & 72.0 & 92.1 \\
14 & 0 & 213.0 & 161.7 & 63.5 & 53.1 & 70.6 \\
15 & 0 & 171.6 & 130.4 & 54.0 & 44.9 & 58.1 \\
16 & 0 & 125.7 & 95.9 & 31.6 & 27.9 & 40.6 \\
\hline
\end{tabular}

Table 30 WOOL PRODUCTION COEFFICIENTS (kg/annum/25 ha)

\begin{tabular}{lcrrrrr}
\hline $\begin{array}{l}\text { Land class } \\
\text { group }\end{array}$ & $\begin{array}{c}\text { Forestry Specialist } \\
\text { dairy }\end{array}$ & $\begin{array}{c}\text { Mainly } \\
\text { dairy }\end{array}$ & \multicolumn{3}{c}{ Livestock rearing } \\
& & & & & \multicolumn{3}{c}{$\begin{array}{c}\text { Cattle } \\
\text { \& sheep }\end{array}$} & \\
\hline $1,2,3,4,9,12$ & 0 & 8.9 & 24.3 & 19.5 & 34.0 & 41.7 \\
$5,6,7,8$ & 0 & 4.8 & 13.2 & 10.6 & 18.6 & 22.7 \\
10,11 & 0 & 15.5 & 42.1 & 33.9 & 59.1 & 72.4 \\
13 & 0 & 61.2 & 166.7 & 134.3 & 233.8 & 286.4 \\
14 & 0 & 49.3 & 134.2 & 108.1 & 188.2 & 230.5 \\
15 & 0 & 41.1 & 112.0 & 90.2 & 157.1 & 192.4 \\
16 & 0 & 31.9 & 86.8 & 69.9 & 121.7 & 149.0 \\
\hline
\end{tabular}

Table 31 LABOUR COEFFICIENTS (SMD/annum/25 ha)

\begin{tabular}{lrrrrrr}
\hline $\begin{array}{l}\text { Land class } \\
\text { group }\end{array}$ & $\begin{array}{r}\text { Forestry Specialist } \\
\text { dairy }\end{array}$ & $\begin{array}{c}\text { Mainly } \\
\text { dairy }\end{array}$ & \multicolumn{3}{c}{ Lattle } & \multicolumn{2}{c}{$\begin{array}{c}\text { Cattle } \\
\text { \& sheep }\end{array}$} & Sheep \\
& & & & & & \\
& & & & & & \\
$1,2,3,4,9,12$ & 85.1 & 20.5 & 22.5 & 16.7 & 20.3 & 23.3 \\
$\mathbf{5 , 6 , 7 , 8}$ & 8.1 & 5.9 & 8.9 & 6.9 & 10.1 & 12.1 \\
10,11 & 101.5 & 49.2 & 49.4 & 35.7 & 38.1 & 42.3 \\
13 & 96.1 & 245.4 & 218.9 & 142.7 & 145.6 & 164.4 \\
14 & 112.0 & 198.0 & 176.8 & 118.0 & 119.6 & 133.8 \\
15 & 113.4 & 165.9 & 148.3 & 100.9 & 101.8 & 112.9 \\
16 & 117.5 & 131.9 & 113.7 & 79.3 & 80.0 & 88.1 \\
\hline
\end{tabular}

Table 32 TIMBER PRODUCTION COEFFICIENTS (m³/annum/25 ha)

\begin{tabular}{lrccccc}
\hline $\begin{array}{l}\text { Land class } \\
\text { group }\end{array}$ & $\begin{array}{r}\text { Forestry Specialist } \\
\text { dairy }\end{array}$ & $\begin{array}{c}\text { Mainly } \\
\text { dairy }\end{array}$ & \multicolumn{3}{c}{ Livestock rearing } \\
Cattle & $\begin{array}{c}\text { Cattle } \\
\text { \& sheep }\end{array}$ \\
\hline $1,2,3,4,9,12$ & 154 & 1 & 1 & 1 & 1 & 1 \\
$5,6,7,8$ & 15 & 0 & 0 & 0 & 0 & 0 \\
10,11 & 186 & 2 & 2 & 2 & 2 & 2 \\
13 & 173 & 2 & 2 & 2 & 2 & 2 \\
14 & 206 & 3 & 3 & 3 & 3 & 3 \\
15 & 208 & 4 & 4 & 4 & 4 & 4 \\
16 & 218 & 5 & 5 & 5 & 5 & 5 \\
\hline
\end{tabular}




ISBN 0904282627

\section{Price $f 3.00$ net}

